Prepared in cooperation with the Massachusetts Department of Environmental Protection

\title{
Updating Data Inputs, Assessing Trends, and Evaluating a Method To Estimate Probable High Groundwater Levels in Selected Areas of Massachusetts
}

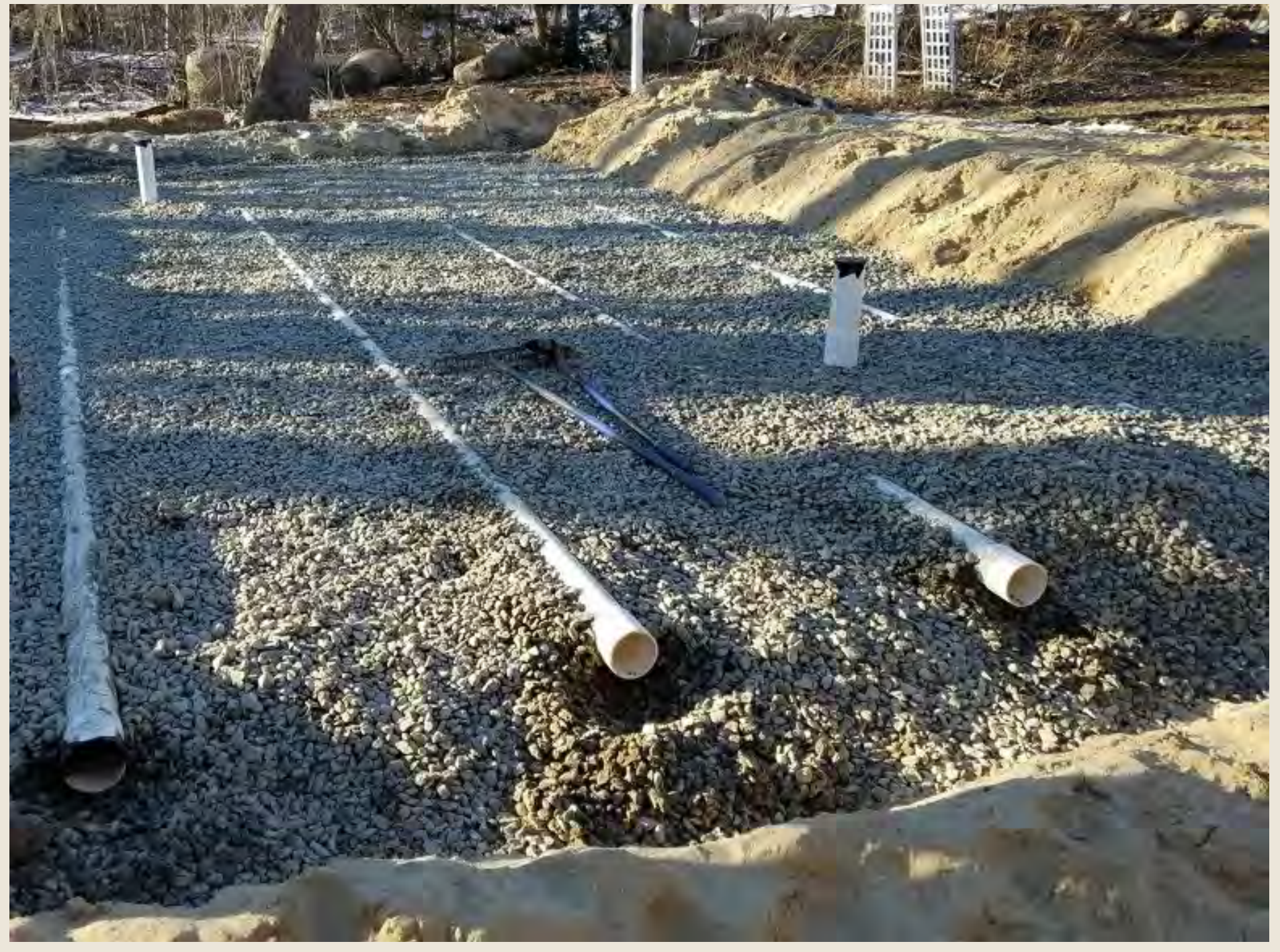

Scientific Investigations Report 2020-5036

U.S. Department of the Interior U.S. Geological Survey 
Cover. Septic system installation, eastern Massachusetts. Photograph by Tim McCobb, U.S. Geological Survey. 


\section{Updating Data Inputs, Assessing Trends, and Evaluating a Method To Estimate Probable High Groundwater Levels in Selected Areas of Massachusetts}

By Janet R. Barclay and John R. Mullaney

Prepared in cooperation with the Massachusetts Department of Environmental

Protection

Scientific Investigations Report 2020-5036 


\title{
U.S. Department of the Interior \\ DAVID BERNHARDT, Secretary
}

\author{
U.S. Geological Survey \\ James F. Reilly II, Director
}

U.S. Geological Survey, Reston, Virginia: 2020

For more information on the USGS - the Federal source for science about the Earth, its natural and living resources, natural hazards, and the environment—visit https://www.usgs.gov or call 1-888-ASK-USGS.

For an overview of USGS information products, including maps, imagery, and publications, visit https://store.usgs.gov/.

Any use of trade, firm, or product names is for descriptive purposes only and does not imply endorsement by the U.S. Government.

Although this information product, for the most part, is in the public domain, it also may contain copyrighted materials as noted in the text. Permission to reproduce copyrighted items must be secured from the copyright owner.

Suggested citation:

Barclay, J.R., and Mullaney, J.R., 2020, Updating data inputs, assessing trends, and evaluating a method to estimate probable high groundwater levels in selected areas of Massachusetts: U.S. Geological Survey Scientific Investigations Report 2020-5036, 45 p., https://doi.org/10.3133/sir20205036.

Associated data for this publication:

Barclay, J.R., and Mullaney, J.R., 2020, Data on well characteristics and well-pair characteristics for estimating high groundwater levels in selected areas of Massachusetts: U.S. Geological Survey data release, https://doi.org/10.5066/P9NM2PHP.

ISSN 2328-0328 (online) 


\section{Acknowledgments}

The authors would like to thank Joseph Cerutti, Bruce Bouck, and Paul Blain from the Massachusetts Department of Environmental Protection for their feedback and contributions to this report. The authors would also like to thank Gregory Granato, Sara Levin, and Gardner Bent of the U.S. Geological Survey for their thoughtful feedback on an initial draft of this report. Finally, the authors would like to recognize the dedicated hydrologic technicians and hydrologists who collected the water-level data described in this report. 



\section{Contents}

Acknowledgments ……...................................................................................................................

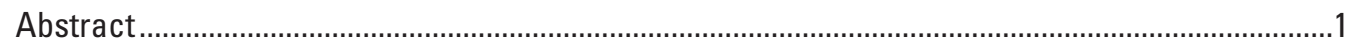

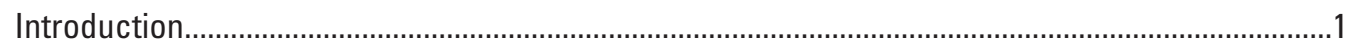

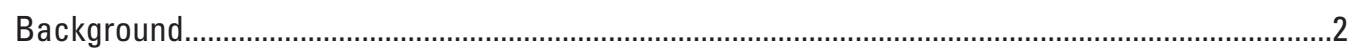

Well Network

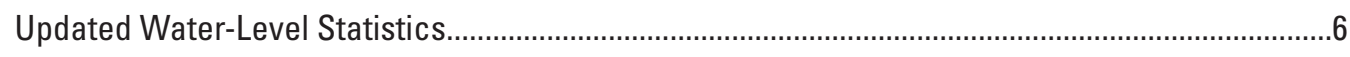

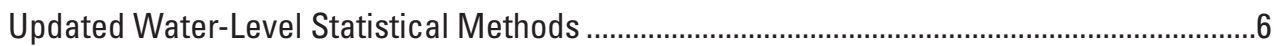

Updated Water-Level Statistical Results ...............................................................................

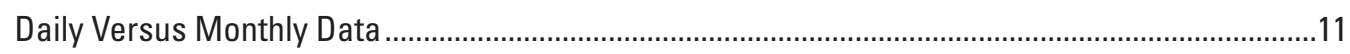

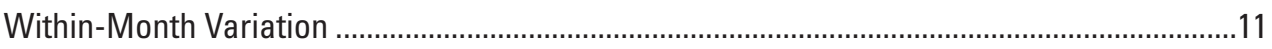

Monthly Versus Daily Mean Groundwater-Level Data ............................................................12

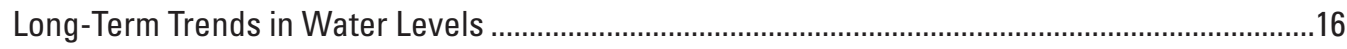

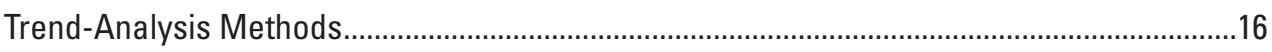

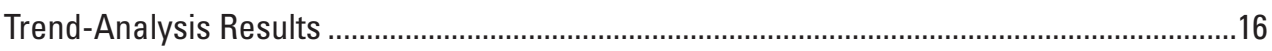

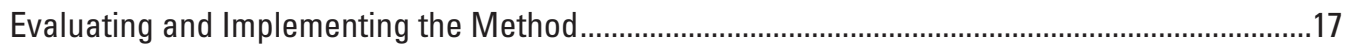

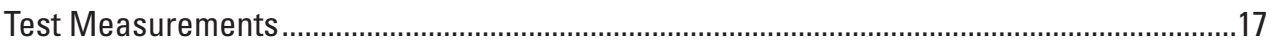

Approaches To Estimating the Annual Groundwater-Level Range .......................................20

Identifying the Topographic Setting of a Test Site ......................................................22

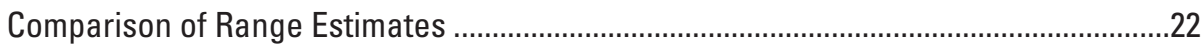

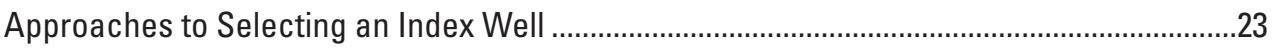

Correlations Between Wells ....................................................................................23

Predictive Equation for Index Well Selection .............................................................24

Comparison of Index Well Selection Approaches ……………………………….......25

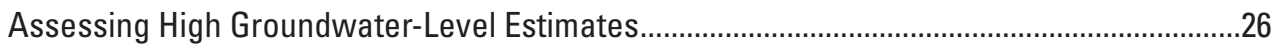

Accuracy of Estimated High Groundwater Level .........................................................26

Frequency of Exceeding the Estimated High Groundwater Level ..................................28

Accuracy of Septic-System-Suitability Classification.........................................................32

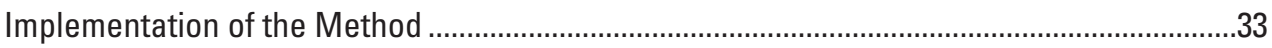

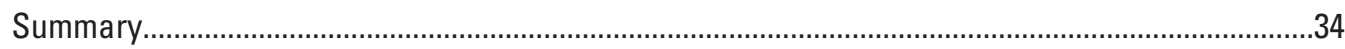

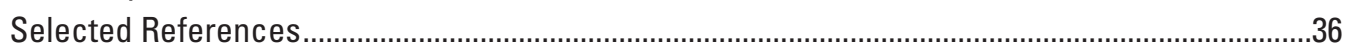

Appendix 1. Groundwater Observation Wells in Massachusetts and Surrounding States.........38

Appendix 2. Description of Data Used in the Predictive Equation To Select the Best

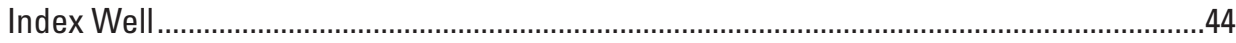

\section{Figures}

1. Diagrams showing schematic overview of the method for estimating probable high groundwater levels at a well in Massachusetts from an index well............................3

2. Map showing locations of 153 groundwater observation wells in Massachusetts and surrounding States used in analysis of groundwater levels...............................

3. Boxplots showing highest recorded groundwater levels in feet below land surface by surficial deposit and topographic setting for 119 U.S. Geological Survey observation wells in Massachusetts and surrounding States, excluding Cape Cod and the islands 
4. Boxplots showing maximum annual groundwater-level ranges in feet by surficial deposit and topographic setting for 119 U.S. Geological Survey observation wells in Massachusetts and surrounding States, excluding Cape Cod and the islands.

5. Normal probability plots of maximum annual groundwater-level range for wells in glacial till in upland and near-stream topographic settings in Massachusetts and surrounding States

6. Normal probability plots of the 90th percentile of annual groundwater-level range for till wells in upland and near-stream topographic settings in Massachusetts and surrounding States.

7. Probability plots of maximum annual groundwater-level ranges for stratified-drift wells in hill and valley topographic settings in Massachusetts and surrounding States

8. Probability plots of the 90th percentile of annual groundwater-level ranges for stratified drift wells in hill and valley topographic settings in Massachusetts and surrounding States

9. Graphs showing within-month variation of groundwater levels, as indicated by the interquartile range in water levels, for 28 continuous-record wells in Massachusetts and surrounding States by surficial deposit and location and by surficial deposit and topographic setting (does not include wells on Cape Cod or the islands)

10. Graphs showing within-month variation, as indicated by the interquartile range of water levels within a given month, and groundwater-level extremes for 28 continuous-record wells in Massachusetts and surrounding States

11. Boxplot showing monthly patterns of within-month variations indicated by the interquartile ranges of water levels for 28 continuous-record wells in Massachusetts and surrounding States

12. Boxplots showing change in calculated annual groundwater-level range by well location and high groundwater level by type of surficial deposit using daily instead of monthly groundwater-level data for 28 wells with continuous groundwater-level records in Massachusetts and surrounding States

13. Boxplots showing magnitudes of trends in high groundwater-level, low groundwater-level, and annual groundwater-level ranges for six periods for wells in Massachusetts and surrounding States.

14. Graphs showing likelihoods of trends in high groundwater, low groundwater, and annual groundwater-level ranges during six periods for wells in Massachusetts and surrounding States

15. Graphs showing likelihood of trends in monthly groundwater levels during six periods for wells in Massachusetts and surrounding States

16. Graph showing mean monthly groundwater levels in wells in stratified-drift deposits in hill and valley topographic settings

17. Graphs showing evaluation of estimations of the maximum and 90th-percentile annual groundwater-level range.

18. Boxplots showing comparison of Spearman's rho for index wells chosen by six different approaches for test wells in till and stratified-drift deposits in Massachusetts and surrounding States

19. Boxplots showing differences between predicted and measured high groundwater levels for wells in Massachusetts and surrounding States 
20. Boxplots showing differences between predicted and measured high groundwater levels for wells in Massachusetts and surrounding States at the time of the test measurement.

21. Graphs showing percentage of sites where the observed groundwater level never or often exceeded the estimated high groundwater level in Massachusetts and surrounding States for five approaches to selecting an index well and for two approaches to estimating the annual groundwater-level range.

22. Boxplots showing percentage of months in which groundwater levels exceeded the estimated high groundwater level for wells in Massachusetts and surrounding States where the estimated high groundwater level was exceeded one or more times.

23. Graphs showing accuracy of determination of suitability for an unmounded septic system for wells in Massachusetts and surrounding States.

\section{Tables}

1. Confidence levels and corresponding trend-likelihood descriptions.

2. Periods used in the trend analysis of groundwater levels for U.S. Geological Survey observation wells in Massachusetts and surrounding States

3. Magnitudes and directions of trends in annual high groundwater levels in wells in Massachusetts and surrounding States for six periods.

4. Magnitudes of trends in annual low groundwater levels in wells in Massachusetts and surrounding States for six periods.

5. Magnitudes of trends in annual groundwater-level ranges for six periods for wells in Massachusetts and surrounding States

6. Correlations between well-pair water-level correlations and possible predictor variables for wells in Massachusetts and surrounding States

7. Regression coefficients for an equation to predict the correlation between an index well and a test well for wells in Massachusetts and surrounding States

8. Errors in estimated high groundwater levels for wells in Massachusetts and surrounding States

\section{Conversion Factors}

U.S. customary units to International System of Units

\begin{tabular}{llll}
\hline \multicolumn{1}{c}{ Multiply } & \multicolumn{1}{c}{ By } & \multicolumn{1}{c}{ To obtain } \\
\hline foot (ft) & 0.3048 & meter $(\mathrm{m})$ & \\
mile (mi) & 1.609 & kilometer $(\mathrm{km})$ & \\
\hline
\end{tabular}




\section{Datum}

Vertical coordinate information is referenced to the North American Vertical Datum of 1988 (NAVD 88).

Horizontal coordinate information is referenced to the North American Datum of 1983 (NAD 83).

Elevation, as used in this report, refers to distance above the vertical datum.

\section{Abbreviations}

$\begin{array}{ll}\text { BIC } & \text { Bayesian information criterion } \\ \text { ppcc } & \text { probability-plot correlation coefficient } \\ \text { USGS } & \text { U.S. Geological Survey }\end{array}$




\title{
Updating Data Inputs, Assessing Trends, and Evaluating a Method To Estimate Probable High Groundwater Levels in Selected Areas of Massachusetts
}

\author{
By Janet R. Barclay and John R. Mullaney
}

\section{Abstract}

A method to estimate the probable high groundwater level in Massachusetts, excluding Cape Cod and the islands, was developed in 1981. The method uses a groundwater measurement from a test site, groundwater measurements from an index well, and a distribution of high groundwater levels from wells in similar geologic and topographic settings. The U.S. Geological Survey, in cooperation with the Massachusetts Department of Environmental Protection, conducted an update to the Frimpter method for estimating the probable high groundwater levels in Massachusetts. The study evaluated the potential changes to the method resulting from four decades of additional groundwater-level data and the expansion of the network of wells for monitoring groundwater levels. The differences and potential benefits of daily, as opposed to monthly, measurements in the application of the method were examined because of the increased availability of high-frequency (subdaily) groundwater-level data. The study also considered long-term trends in groundwater levels that may alter the accuracy of the method. Finally, the accuracy of the estimated high groundwater levels was evaluated, and improved implementation guidance was prepared.

For this study, groundwater levels in 153 wells in Massachusetts and surrounding States with records with lengths of 16 to 78 years were analyzed. The highest recorded groundwater levels ranged from 1.2 feet (ft) above land surface (flooded conditions) to $45.8 \mathrm{ft}$ below land surface, with a median of $4.6 \mathrm{ft}$ below land surface. The maximum annual groundwater-level range was 1.4 to $17.9 \mathrm{ft}$, with a median of $5.5 \mathrm{ft}$.

The within-month variation, maximum annual groundwater-level range, and highest recorded groundwater level were computed using daily mean groundwater-level values from 28 wells with continuous records. The use of daily data resulted in larger maximum annual groundwaterlevel ranges ( 0.02 to $2.94 \mathrm{ft}$ larger, with a median of $0.58 \mathrm{ft}$ larger) and shallower highest-recorded groundwater levels ( 0.0 to $1.60 \mathrm{ft}$ shallower, with a median of $0.18 \mathrm{ft}$ shallower) than computations based on monthly measurements in the same wells.
Statistical tests showed moderate to strong evidence of trends in measurements of both high and low groundwater levels within most of the periods during which water levels were analyzed. High groundwater levels rose beneath the land surface at most sites during four of the six periods used for analysis (1966-2015, 1986-2015, 1991-2010, and 1981-2010). Low groundwater levels also increased at many sites during most of the periods evaluated, but this trend was less widespread than the similar trends in high groundwater levels, and the trend was to deeper low groundwater levels at more sites than the trend to deeper high groundwater levels. There was no clear trend in annual groundwater-level ranges at most sites during the six periods analyzed.

In general, the Frimpter method predicted shallower (higher) high groundwater levels than were observed but correctly classified sites according to their suitabilities for unmounded septic systems. The mean error of the predictions (difference between the estimated and observed groundwater levels) ranged from $-3.23 \mathrm{ft}$ to $-1.40 \mathrm{ft}$ for various approaches to estimating the groundwater-level range and selecting an index well. The method correctly classified 83 to 86 percent of monitoring-well sites according to their suitability for an unmounded septic system for many approaches to estimating the annual groundwater-level range and selecting an index well. The approach selected for estimating the annual groundwater-level range and selecting an index well will depend upon the importance of an accurate estimate of the high groundwater level as compared to the importance of an estimated high groundwater level that is less likely to be exceeded.

\section{Introduction}

For performance and regulatory reasons, septic-system drainage fields must be sited above the high groundwater level (U.S. Environmental Protection Agency, 2002; Massachusetts Department of Environmental Protection, 2016). Septic systems remove contaminants such as bacteria and soap residues from waste effluent as it percolates through unsaturated soil in the leach field. Saturated conditions interfere with contaminant 
removal, leading to groundwater contamination and possibly backlogged sewage (U.S. Environmental Protection Agency, 2001). To prevent these problems, Massachusetts requires that the vertical separation between the bottom of the soilabsorption system and the high groundwater level be 4 or 5 feet ( $\mathrm{ft}$ ), depending upon the percolation rate (Massachusetts Department of Environmental Protection, 2016). It can be difficult, however, to determine the high groundwater level at a site if redoximorphic features, such as color changes, indicating the elevation of the water table are absent from the soil profile. For these situations, an alternative approach commonly called the Frimpter method was developed (Frimpter, 1981).

Although the Frimpter method is currently [2020] in widespread use in Massachusetts (Massachusetts Department of Environmental Protection, 2016), the underlying analysis is based on water-level measurements collected before April 1977. The U.S. Geological Survey, in cooperation with the Massachusetts Department of Environmental Protection, updated the Frimpter method. This report describes the update to the distribution of water levels, an analysis of within-month variation in groundwater levels, an assessment of the differences in high groundwater levels based on monthly measurements versus observed daily mean groundwater levels, an assessment of long-term trends in groundwater levels, an evaluation of the accuracy of the method using multiple approaches to estimating the annual groundwater-level range and selecting an index well for a test site, and guidance on estimating the annual groundwater-level range and selecting an appropriate index well for a test site.

\section{Background}

The primary purposes of this report are to (1) update the input data for the Frimpter method using approximately 40 years of additional groundwater-level data and an expanded network of wells, (2) quantify within-month variations in groundwater levels that may be missed by monthly measurements, (3) quantify differences in calculated high groundwater levels and annual groundwater-level ranges on the basis of monthly groundwater levels and daily mean groundwater levels, (4) identify the long-term trends in annual high and low groundwater levels and annual groundwater-level ranges, (5) provide guidance on the selection of an index well and estimation of the annual groundwater-level range, (6) evaluate application of the Frimpter method when using the current network of wells, and (7) provide guidance on implementing the Frimpter method.

Within-month variation, monthly versus daily measurements, and long-term trends were calculated from analyses of water-level data for wells in Massachusetts (including
Cape Cod and the islands) and surrounding States. Currently [2020], the Frimpter method is implemented slightly differently on Cape Cod and the islands (Frimpter and Belfit, 2006); therefore, analyses specific to implementing the Frimpter method - updated probability distributions, indexwell and range-selection guidance, and method-performance evaluation - include only wells on the mainland of Massachusetts and in surrounding States.

The method (Frimpter, 1981) is based on the theory that the ratio of the rise from current to high groundwater to the estimated maximum annual groundwater-level range at the test site is equal to the ratio of the rise from current to high groundwater to the maximum annual groundwater-level range at an index well (fig. 1). This relation is described by equation 1 , which can be rearranged to yield equation 2 for easier calculation of the probable high groundwater level at the test site $(S h)$, as follows:

$$
\begin{gathered}
\frac{S c-S h}{S r}=\frac{O W c-O W \max }{O W r}, \text { or } \\
S h=S c-\frac{S r}{O W r}(O W c-O W \max ),
\end{gathered}
$$

where

$$
\begin{gathered}
S c \quad \text { is the current groundwater level at the } \\
\text { test site; } \\
\mathrm{Sr} \quad \text { is an estimate of the annual groundwater-level } \\
\text { range at the test site; } \\
\text { OWc is the current groundwater level at an } \\
\text { index well; } \\
\text { OWmax } \quad \begin{array}{c}
\text { is the historical high groundwater level at an } \\
\text { index well; and }
\end{array} \\
\mathrm{OWr} \quad \text { is the annual groundwater-level range at an } \\
\text { index well. }
\end{gathered}
$$

$S c$ is measured at the test site, $S r$ is an estimate based on a probability distribution, $O W C$ is obtained from groundwatermonitoring records, and $\mathrm{OWr}$ and $\mathrm{OWmax}$ are obtained from compiled statistics of previously measured values.

The original Frimpter method is currently [2020] used to estimate probable high groundwater levels on the mainland of Massachusetts (Massachusetts Department of Environmental Protection, 2016). A similar analysis was completed for Rhode Island (Socolow and others, 1994) and found that the accuracy of the method was sufficient for septic-system design. A variation of the method that specifies index wells on the basis of mapped zones is used for Cape Cod and the islands (Frimpter and Fisher, 1983; Frimpter and Belfit, 2006; Massachusetts Department of Environmental Protection, 2016). 


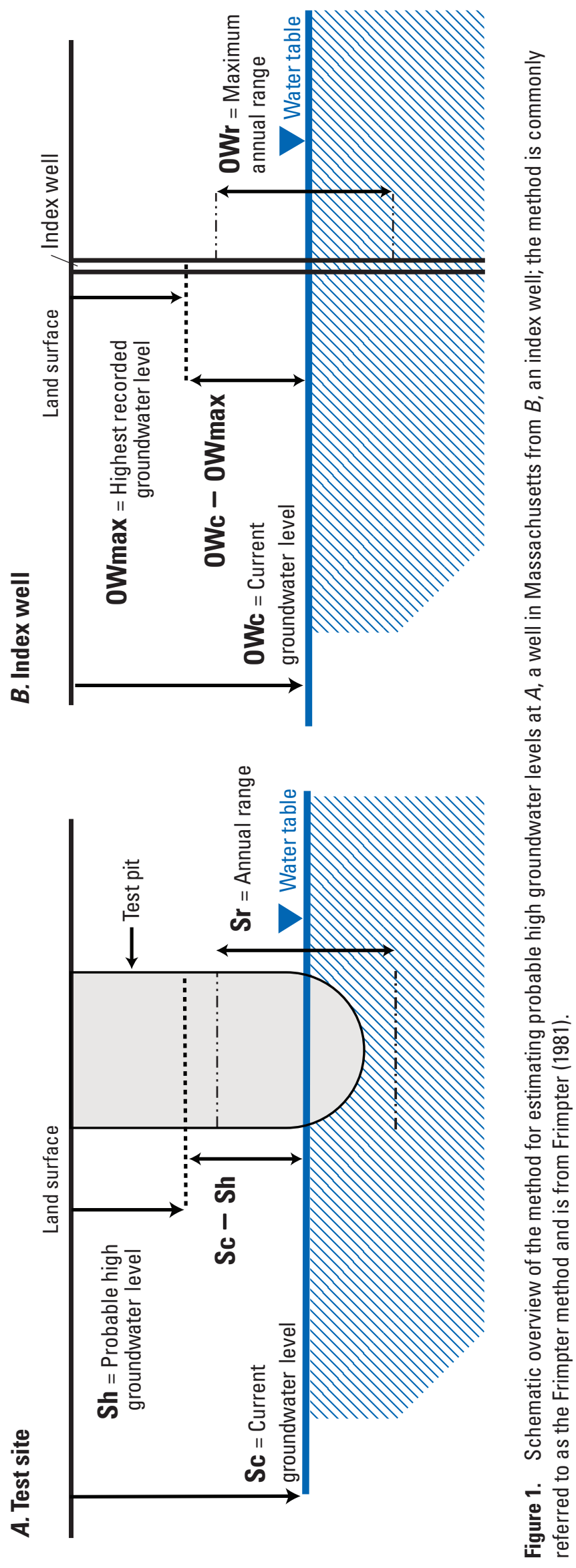




\section{Well Network}

Groundwater levels were analyzed from 153 wells (99 in Massachusetts, 30 in Connecticut, 22 in Rhode Island, 1 in Vermont, and 1 in New Hampshire) that were selected based on their periods of record, proximity to Massachusetts, and typical water levels (fig. 2; app. 1; Barclay and Mullaney, 2020). The selected wells (1) were active at least until water year 12010 ; (2) have 10 or more years of nine or more monthly water-level measurements during the water years since 1995; (3) were dry during fewer than 3 percent of the measurements; (4) were within 25 and 40 miles of Massachusetts, for stratified drift and till wells, respectively; (5) had median groundwater levels less than $30 \mathrm{ft}$ below land surface; (6) were minimally affected by pumping; and (7) were finished in unconsolidated glacial sediments (not bedrock).

The final list of 119 wells includes wells on the mainland of Massachusetts and nearby States (40 in glacial-till deposits and 79 in stratified-drift deposits), and 34 wells on Cape Cod and the islands (app. 1). Periods of records ranged from 16 to 78 years. For analysis, wells were grouped by surficial deposit (glacial till or stratified drift) and topographic setting because of their different hydrologic responses. Glacial-till deposits are unsorted, unstratified sediments that may contain a mixture of sand, silt, and clay, as well as boulders and gravel; in contrast, stratified-drift sediments are sorted and layered and may contain separate layers of sand, gravel, silt, and clay (De Lima, 1991). Two broad topographic-setting groups were used for the till wells (near-stream and upland), and two groups were used for the stratified-drift wells (valley and hill). For till wells, the group identified as "near-stream" was defined as within $328 \mathrm{ft}(100$ meters [m]) horizontally and $16 \mathrm{ft}(5 \mathrm{~m})$ vertically of the nearest stream; all other wells in glacial till were considered upland. The till wells included 32 in upland settings and 8 in near-stream settings. Hill and valley for stratified-drift wells were defined based on the surrounding topography shown on a topographic map. The stratified-drift wells on the mainland of Massachusetts and nearby States included 38 that were on hills and 41 in valleys.

Wells on Cape Cod and the islands were included in analyses of high groundwater levels, annual groundwaterlevel ranges, once-a-month versus observed daily mean water levels, within-month variation, and long-term trends. Wells on Cape Cod were not included in the analyses related to method implementation (updated probability distributions, index-well and annual groundwater-range guidance, or method evaluation) because a slightly different approach for estimating high groundwater levels is in use on Cape Cod (Frimpter and Belfit, 2006). Four wells on Cape Cod with median groundwater levels greater than $30 \mathrm{ft}$ below land surface (MA-BHW 198 Bourne, MA-MIW 29 Mashpee, MA-SDW 252 Sandwich, and MA-SDW 253 Sandwich) were included in the group of Cape Cod wells because they are currently [2020] used as index wells.

The original results of the Frimpter method (Frimpter, 1981) were based on 87 wells on the mainland (of which 15 were finished in till, 49 in stratified drift, 4 in bedrock) and 13 on Cape Cod (which are all finished in stratified drift). Of the wells on the original list, 54 (9 in till on the mainland, 36 in stratified drift on the mainland, and 9 on Cape Cod) were included in this study. Of the remaining 33 wells from the original report that were not included in this study, 25 were discontinued before water year 2010, 5 had median groundwater levels more than $30 \mathrm{ft}$ below the land surface, 1 was affected by pumping, 1 was finished in bedrock, and 1 was obstructed.

1The water year is defined as the 12-month period from October 1 through September 30 of the next year and designated by the calendar year in which it ends. 


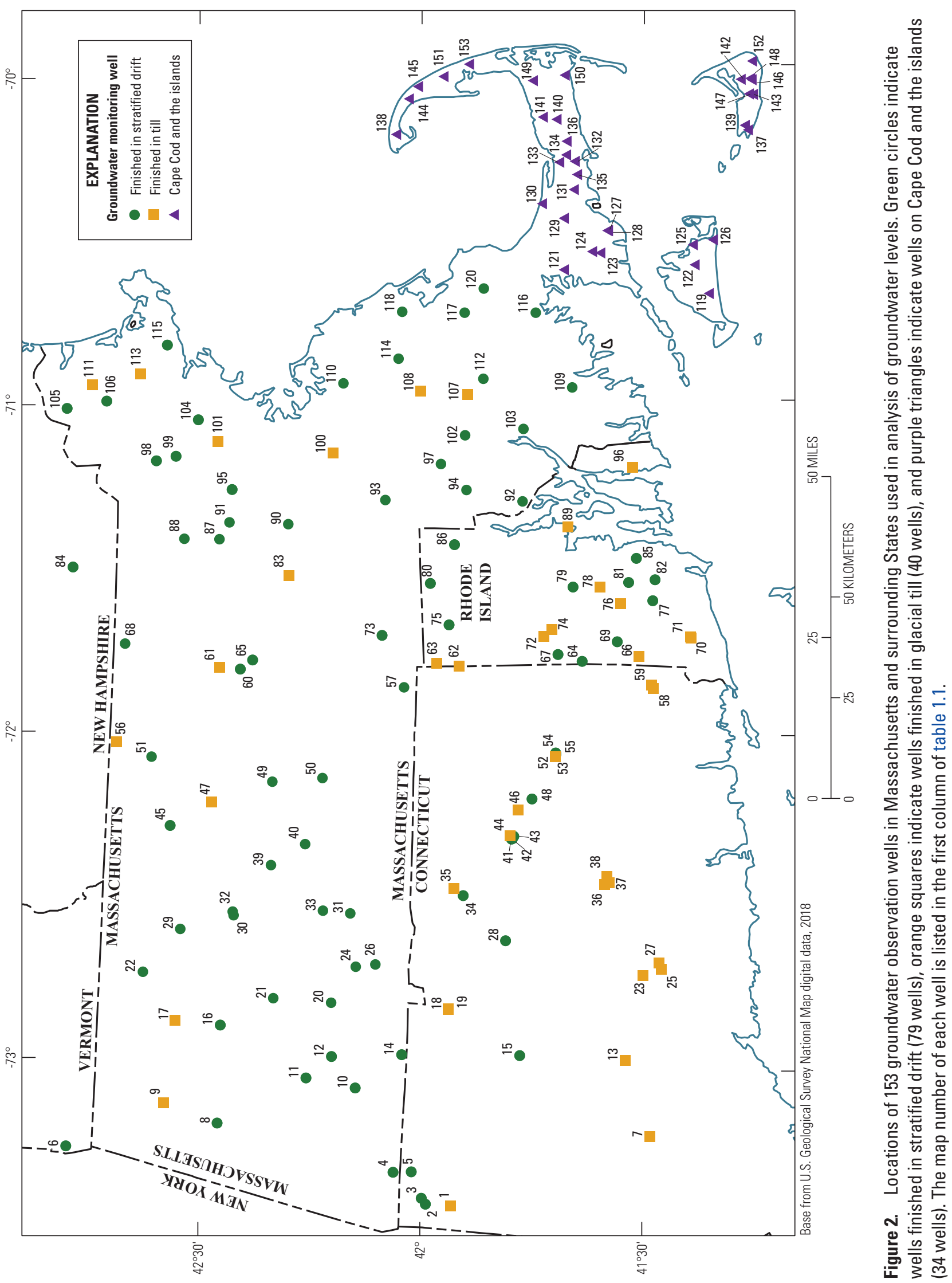




\section{Updated Water-Level Statistics}

Implementation of the method requires an estimate of the annual groundwater-level range at the site of interest. The original report estimated the annual groundwater-level range using the 5-percent exceedance ${ }^{2}$ from a distribution of the maximum annual groundwater-level ranges for wells in similar geologic and topographic settings (Frimpter, 1981). In this study, the distributions of maximum annual (water-year) groundwater-level ranges were updated, and distributions of the 90th-percentile annual (water-year) groundwater-level ranges were also generated. The 90th-percentile distributions reflect more typical conditions by filtering out water years with extremely large water-level ranges and, although not currently [2020] used, were generated in preparation for improved guidance in implementing the method.

\section{Updated Water-Level Statistical Methods}

To update these distributions, the groundwater-level range for each water year for each well was calculated, and the maximum and 90th-percentile annual groundwater-level ranges for each well were selected. The highest (shallowest) and 90th-percentile groundwater levels for each well for its period of record also were identified. If available, daily mean groundwater levels were used, and otherwise monthly measurements were used. The analysis for each well was based on data from the beginning of the well's period of record through water year 2017 from water years with nine or more waterlevel measurements (Barclay and Mullaney, 2020).

Wells were grouped by surficial deposits (till and stratified drift) and further divided by topographic setting based on observed differences in the annual groundwater-level range and high groundwater levels. The resulting distributions were displayed graphically on probability plots, with a normal or log-normal distribution as appropriate based on the normality of the annual groundwater-range distribution for each well group. The normality was tested using a probability-plot correlation test (Filliben, 1975; Helsel and Hirsch, 2002) and the smwrStats package in R (U.S. Geological Survey, 2015; R Core Team, 2018).

\section{Updated Water-Level Statistical Results}

The highest recorded groundwater levels in 153 wells in Massachusetts, including Cape Cod and the islands, and surrounding States ranged from $1.2 \mathrm{ft}$ above land surface to $45.8 \mathrm{ft}$ below land surface, with a median of $4.6 \mathrm{ft}$ below land surface (app. 1; Barclay and Mullaney, 2020). Wells in till deposits had higher high groundwater levels (median depth of

\footnotetext{
2The 5-percent exceedance is the value (in this case the maximum annual groundwater-level range) that would be expected to be exceeded at 5 percent of sites. Ninety-five percent of sites would be expected to have a maximum annual groundwater-level range below this value.
}

$2.2 \mathrm{ft}$ ) than wells in stratified-drift deposits (median depth of $4.5 \mathrm{ft}$; fig. $3 \mathrm{~A}$ ), and both groups had higher high groundwater levels than wells on Cape Cod and the islands (median depth of $9.2 \mathrm{ft}$; data not shown). Within each surficial-deposit group (stratified drift or till), the median values were not different by topographic setting at the 95-percent confidence limit (fig. 3B).

The maximum annual groundwater-level range varied from 1.4 to $17.9 \mathrm{ft}$, with a median of $5.5 \mathrm{ft}$, for all 153 wells (Barclay and Mullaney, 2020). Among wells not on Cape Cod and the islands, wells in till deposits had larger maximum annual groundwater-level ranges (median range of $11.4 \mathrm{ft}$ ) than wells in stratified-drift deposits (median range of $5.6 \mathrm{ft}$ ), and the medians were statistically different at the 95-percent confidence limit (fig. 4A). The maximum annual groundwaterlevel ranges for both the stratified-drift and till wells on the mainland were larger than for wells on Cape Cod and the islands (median of $4.4 \mathrm{ft}$; app. 1; Barclay and Mullaney, 2020). On the mainland, stratified-drift wells in valleys (median range of $4.2 \mathrm{ft}$ ) had smaller maximum annual groundwater-level ranges than those on hills (median range of $7.2 \mathrm{ft}$; fig. $4 B$ ). Similarly, among the till wells on the mainland, near-stream wells had smaller maximum annual groundwater-level ranges (median range of $4.5 \mathrm{ft}$ ) than upland wells (median range of $11.9 \mathrm{ft}$ ). Within each surficial-deposit group, median annual groundwater-level ranges for wells in different topographic settings were statistically different at the 95-percent confidence limit. This contrasts with the high groundwater levels for which the median values for each geologic and topographic setting were not statistically different at the 95-percent confidence limit (fig. 3).

The maximum annual groundwater-level ranges for both upland and near-stream groups of till sites were normally distributed, with an upland probability-plot correlation coefficient (ppcc) of 0.99 (normal distribution) and a near-stream ppcc of 0.91 (normal distribution). For upland wells, the 5-percent exceedance level is $16.7 \mathrm{ft}$, with a 95-percent confidence interval of 15.5 to $18.2 \mathrm{ft}$ (fig. $5 \mathrm{~A}$ ), which is similar to the level of $17 \mathrm{ft}$ that was calculated in Frimpter (1981). For nearstream wells, the 5-percent exceedance level is $9.4 \mathrm{ft}$, with a 95-percent confidence interval of 6.3 to 13.4 (fig. $5 B$ ). None of the till wells in Frimpter (1981) were in a near-stream setting.

The 90th percentile of annual groundwater-level ranges for till wells in upland settings (ppcc of 0.97) was also normally distributed (fig. $6 \mathrm{~A}$ ), but the 90th percentile of annual groundwater-level ranges for till wells in near-stream settings (ppcc of 0.9 ; log-normal distribution) was not. For upland wells, the 5-percent exceedance level from the distribution of the 90th percentile of annual ranges is $14.4 \mathrm{ft}$, with a 95-percent confidence interval of 13.2 to $15.7 \mathrm{ft}$ (fig. $6 \mathrm{~A}$ ); for near-stream wells, the 5-percent exceedance level is $7.4 \mathrm{ft}$, with a 95-percent confidence interval of 4.3 to $15.1 \mathrm{ft}$ (fig. $6 B$ ). The distribution of the 90th percentile of annual groundwaterlevel ranges was not considered in Frimpter (1981).

The highest annual groundwater-level ranges for the stratified-drift wells in a hill setting were not normally distributed, but the ranges for the valley wells were, with a hill 

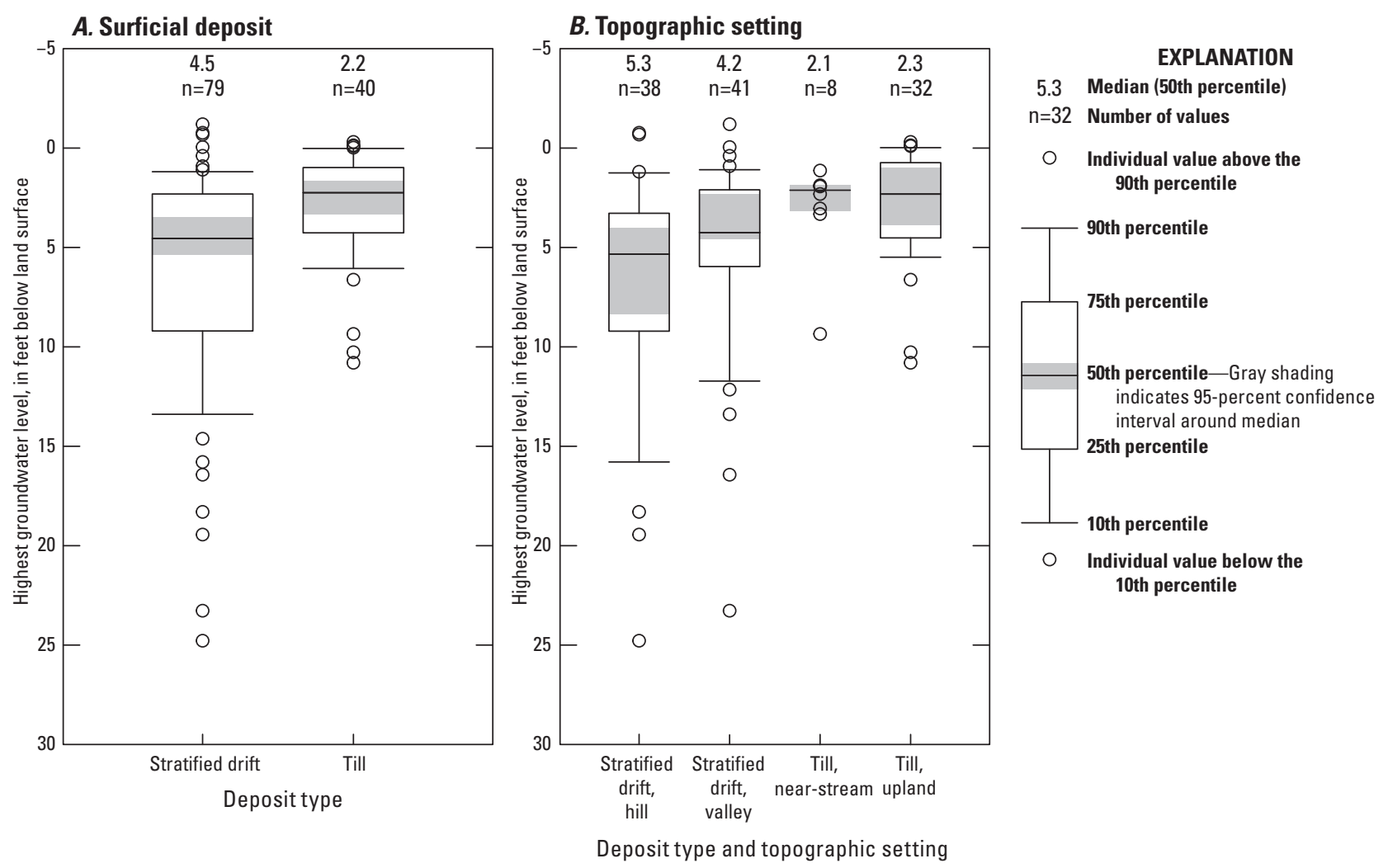

Figure 3. Highest recorded groundwater levels in feet below land surface by $A$, surficial deposit and $B$, topographic setting for 119 U.S. Geological Survey observation wells in Massachusetts and surrounding States, excluding Cape Cod and the islands. Boxes are drawn only for more than 20 values.

ppec of 0.99 (log-normal distribution) and a valley ppec of 0.99 (normal distribution; fig. 7). As a result, the probability plots for the wells in a hill setting were generated using a log-normal distribution, and probability plots for the wells in a valley setting were generated using a normal distribution. The 5-percent exceedance level for hills is $13.8 \mathrm{ft}$, with a 95-percent confidence interval of 11.6 to $16.8 \mathrm{ft}$, and for valley wells is $7.1 \mathrm{ft}$, with a 95-percent confidence interval of 6.5 to $7.8 \mathrm{ft}$. Both of these values are larger than the values of $10.0 \mathrm{ft}$ and $4.2 \mathrm{ft}$ for terrace 3 and valley-flat wells, respectively, that were published in Frimpter (1981). This difference may be due to the addition of wells that were not in the original Frimpter (1981) study and (or) increases in the maximum recorded annual groundwater-level ranges for some wells with the additional 40 years of data.

Similar to the highest annual groundwater-level ranges, the 90th percentile of annual groundwater-level ranges for the stratified-drift wells in a hill setting (ppcc of 0.99, log-normal distribution) were not normally distributed, but the ranges for the valley sites (ppcc of 0.99 , normal distribution) were. As a result, the probability plots were generated using a log-normal distribution for the hill wells and a normal distribution for the

\footnotetext{
${ }^{3}$ Terraces are narrow areas of relatively flat topography in the middle of a hillslope (Jackson, 1997). Because identification of terraces can be somewhat ambiguous, in this study, terraces were included in hill topographic settings.
}

valley wells (fig. 8). The 5-percent exceedance level from the distribution of 90th percentiles for hill wells was $12.4 \mathrm{ft}$, with a 95-percent confidence interval of 10.0 to $15.8 \mathrm{ft}$ (fig. $8 A$ ), and for valley wells was $5.4 \mathrm{ft}$, with a 95 -percent confidence interval of 4.9 to $6.0 \mathrm{ft}$ (fig. $8 B$ ).

The choice of distribution (normal or log-normal) had a minor effect on the 5-percent exceedance-probability level. Across all surficial deposits and topographic groups except till wells in near-stream settings, for both the maximum and 90th-percentile annual water-level ranges, the log-normal distribution resulted in a slightly larger (less than 1-ft difference) 5-percent exceedance probability level than the normal distribution. For till wells in near-stream settings, the lognormal distribution resulted in a slightly smaller (less than 0.5 -ft difference) 5-percent exceedance probability level than the normal distribution. Estimates of the 5-percent exceedance probability levels for both normal and log-normal distributions fell within the 95-percent confidence interval for the other distribution except for the estimations of the maximum annual water-level ranges for stratified-drift wells in a valley setting (both distributions) and the estimate of the 90th-percentile annual water-level range for stratified drift wells in a valley setting using a log-normal distribution. 

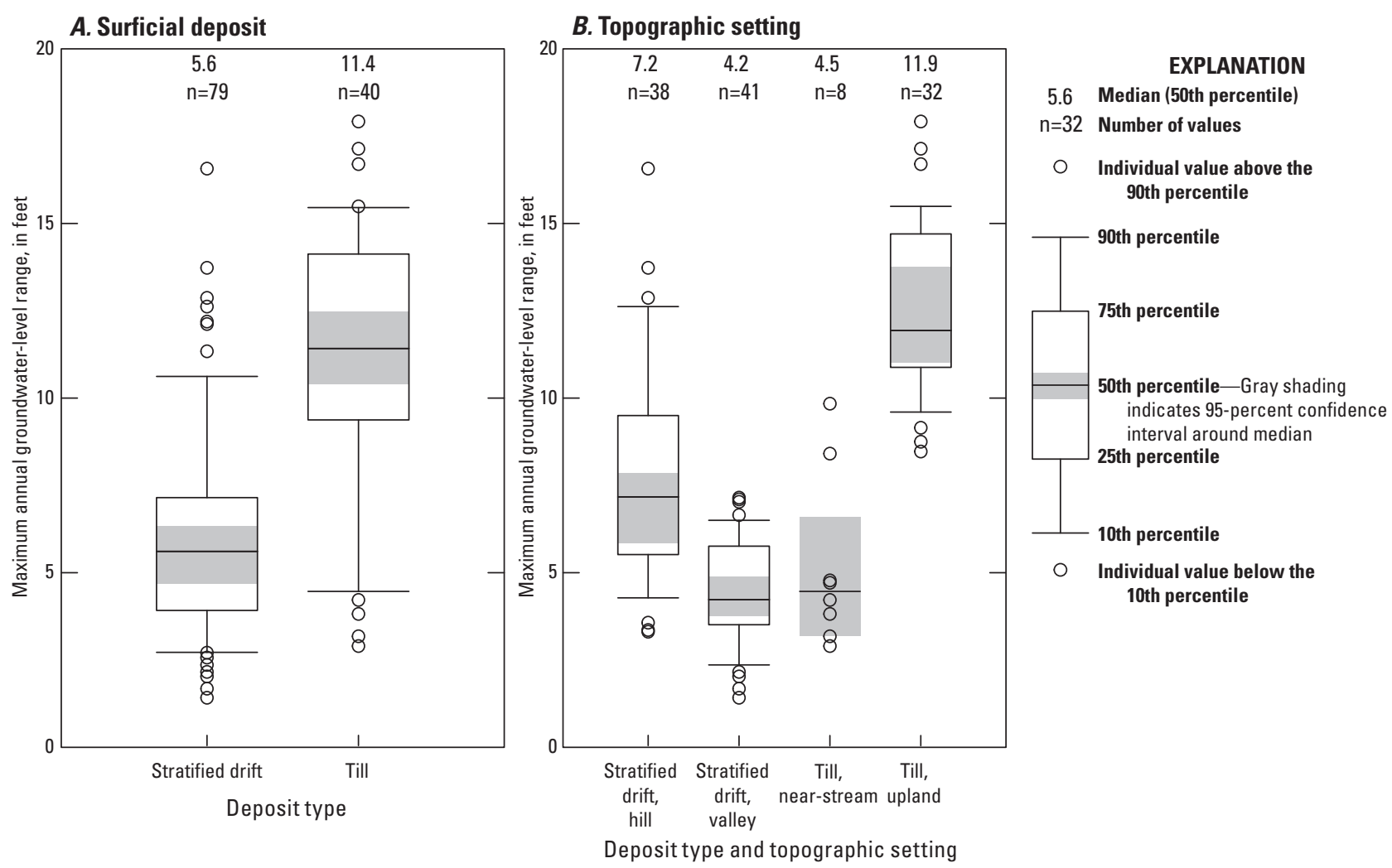

Figure 4. Maximum annual groundwater-level ranges in feet by $A$, surficial deposit and $B$, topographic setting for 119 U.S. Geological Survey observation wells in Massachusetts and surrounding States, excluding Cape Cod and the islands. Boxes are dawn only for more than 20 values. 


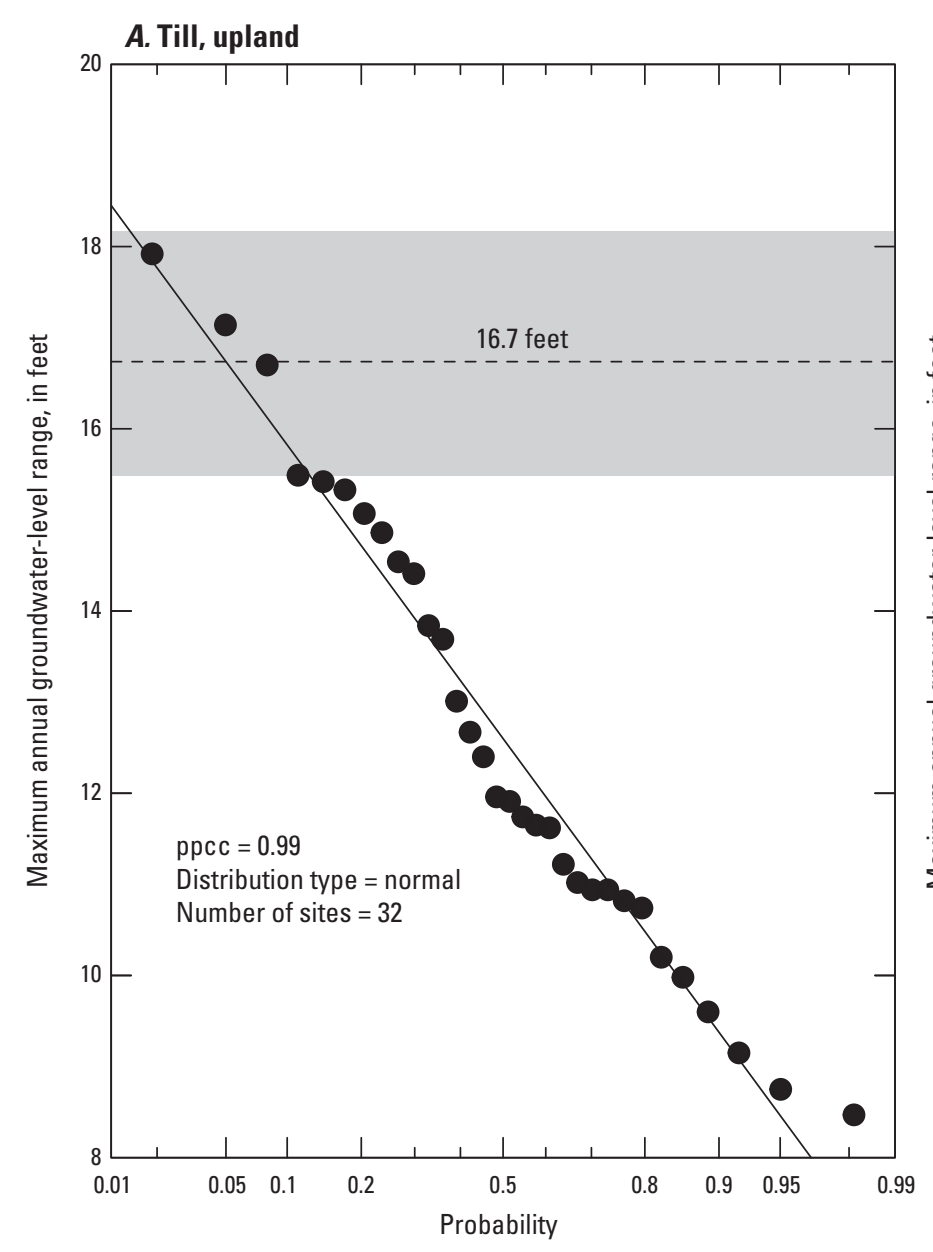

EXPLANATION

95-percent confidence interval around 5-percent exceedance level

5-percent exceedance level

Indicated distribution line

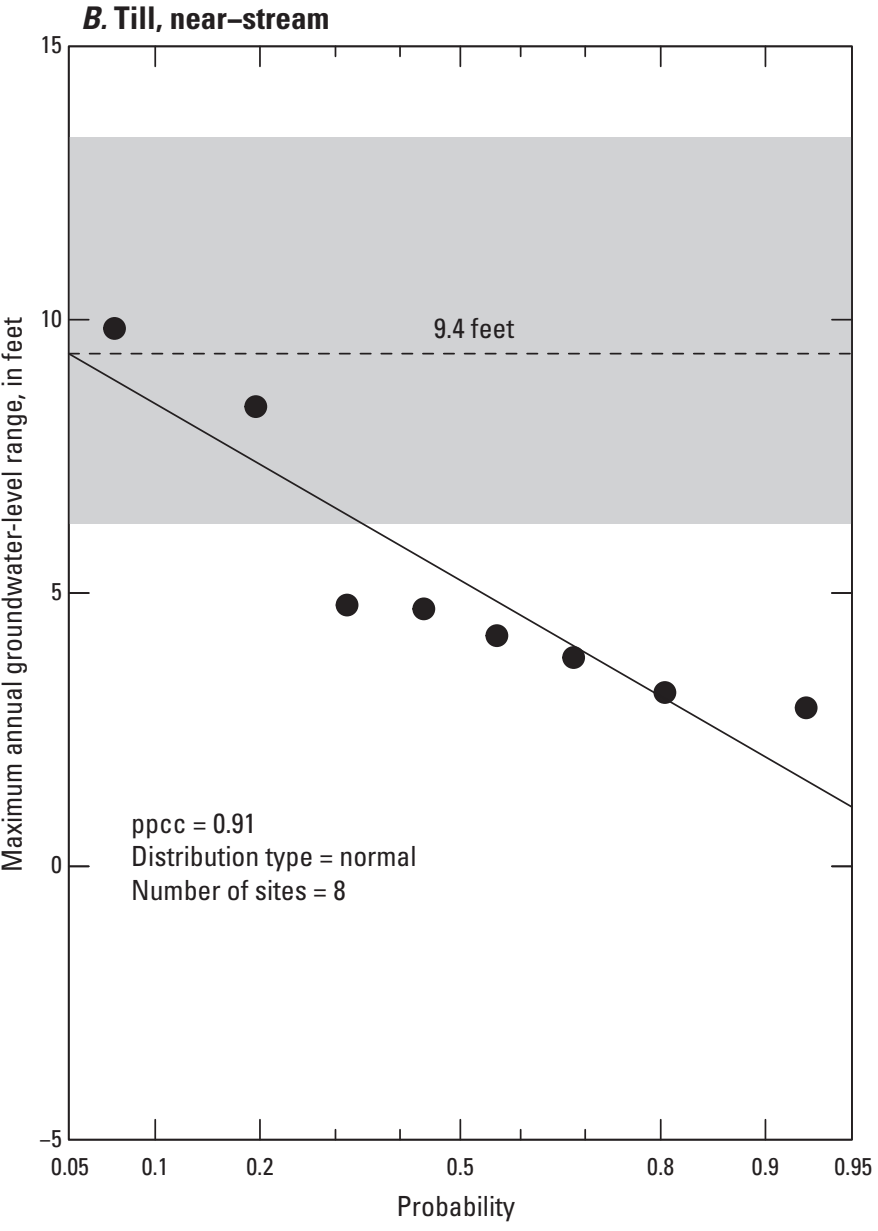

EXPLANATION

95-percent confidence interval around 5-percent exceedance level

5-percent exceedance level

Indicated distribution line

Figure 5. Normal probability plots of maximum annual groundwater-level range for wells in glacial till in $A$, upland and $B$, near-stream topographic settings in Massachusetts and surrounding States. The distribution type indicates the type of distribution (normal or log-normal) that was used for estimating the 5-percent exceedance level. The probability-plot correlation coefficient (ppcc) indicates the goodness of fit to the indicated distribution type, where 1 is a perfect fit. 


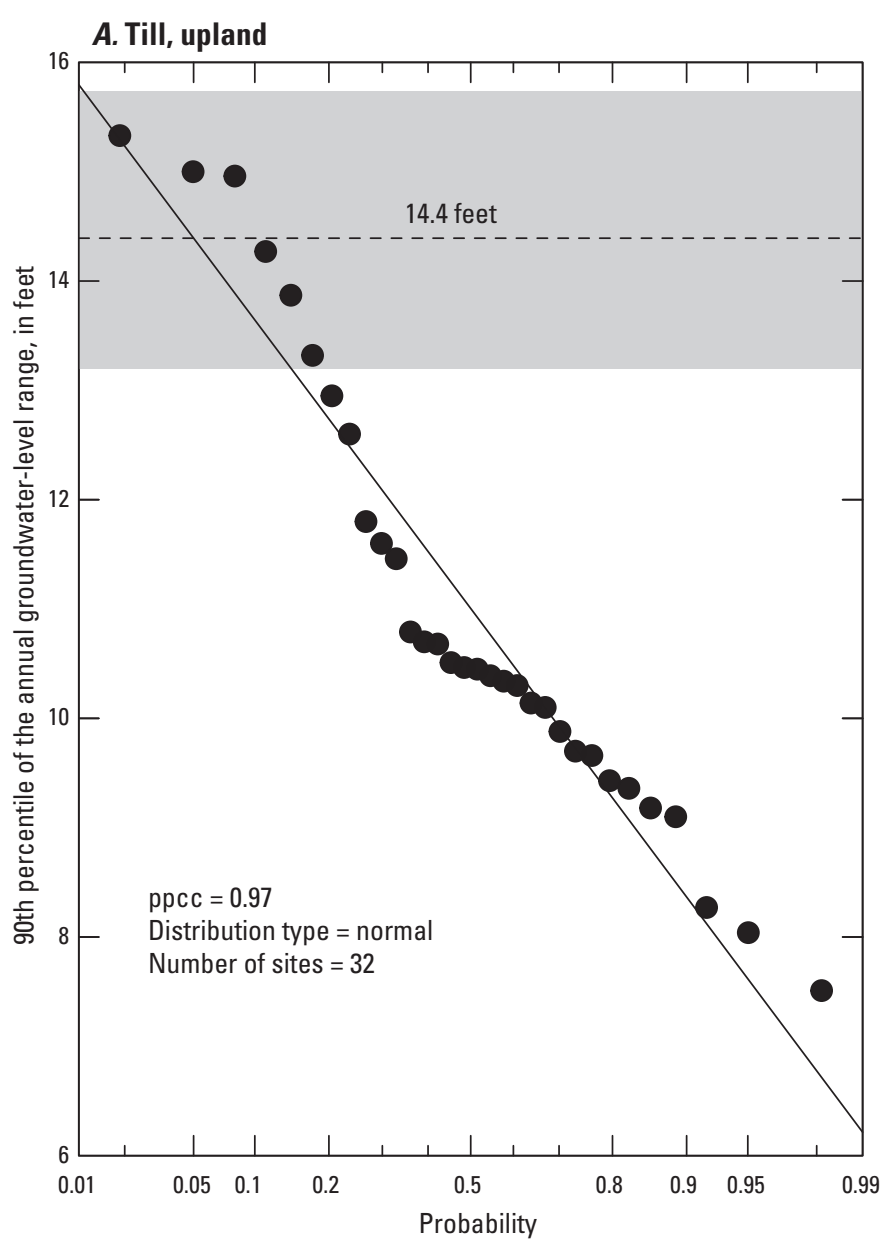

EXPLANATION

95-percent confidence interval around 5-percent exceedance level

- - - - 5-percent exceedance level

Indicated distribution line

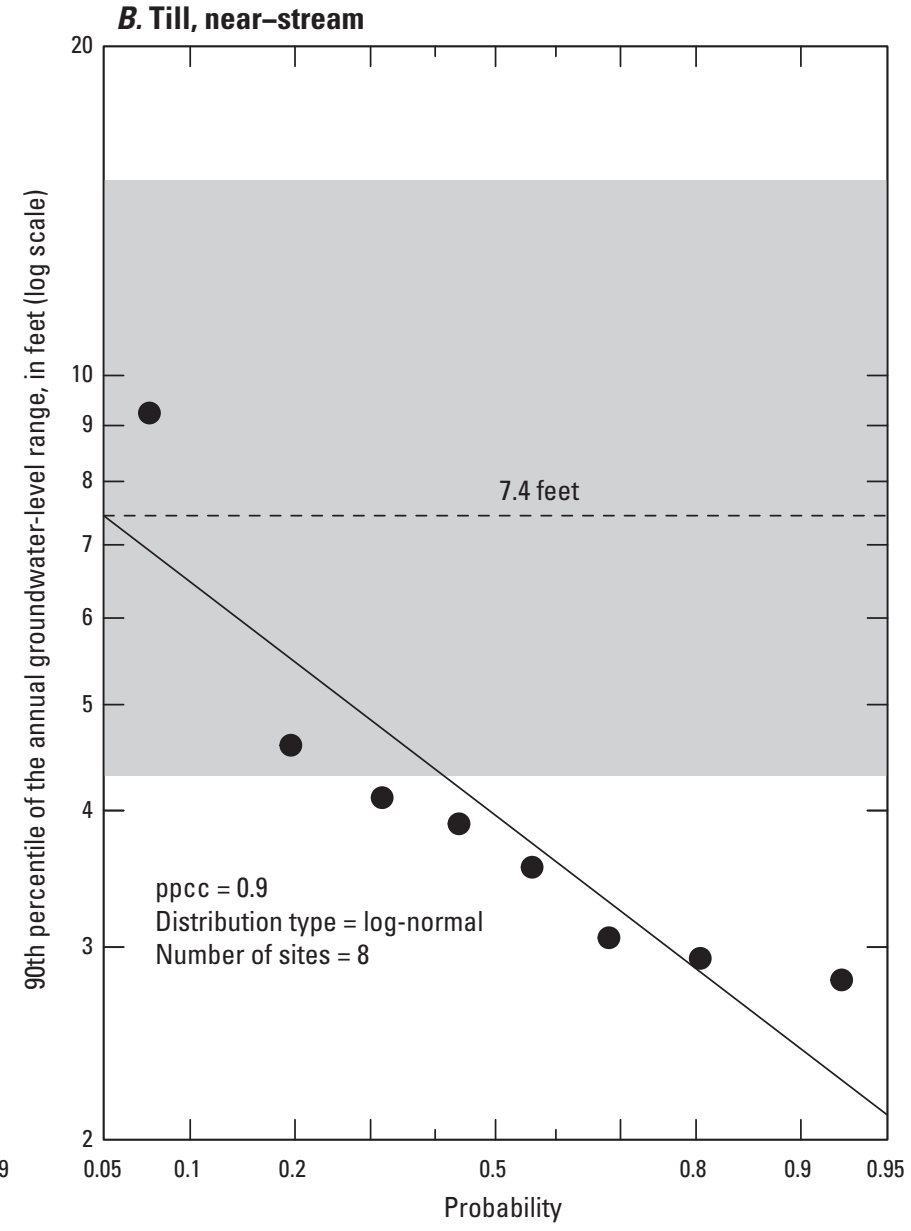

EXPLANATION

95-percent confidence interval

around 5-percent exceedance level

- - - - 5-percent exceedance level

Indicated distribution line

Figure 6. Normal probability plots of the 90th percentile of annual groundwater-level range for till wells in $A$, upland and $B$, near-stream topographic settings in Massachusetts and surrounding States. The distribution type indicates the type of distribution (normal or log-normal) that was used for estimating the 5-percent exceedance level. The probability-plot correlation coefficient (ppcc) indicates the goodness of fit to the indicated distribution type, where 1 is a perfect fit.

Uncertainty in the 5-percent exceedance-probability levels varied with topographic position, statistical distribution, and number of wells. Confidence intervals were large when the number of wells in the surficial deposit and topographicsetting group was small, as in the case of eight wells in glacial till in near-stream settings. Among wells in stratified-drift deposits, confidence intervals were larger for wells in higher topographic positions (hill settings) than for wells in lower topographic positions (valley settings). This difference was likely caused by the larger ranges of annual groundwater-level ranges in wells in higher topographic settings than in lower topographic settings. This pattern of larger confidence intervals for higher topographic positions was not seen in the data for till wells, likely because of the small number of till wells in near-stream settings. Confidence intervals were also larger if a log-normal distribution was used than if a normal distribution was used. Larger confidence intervals indicate greater uncertainty in the annual groundwater-level range and result in greater uncertainty in the estimated high groundwater level. 

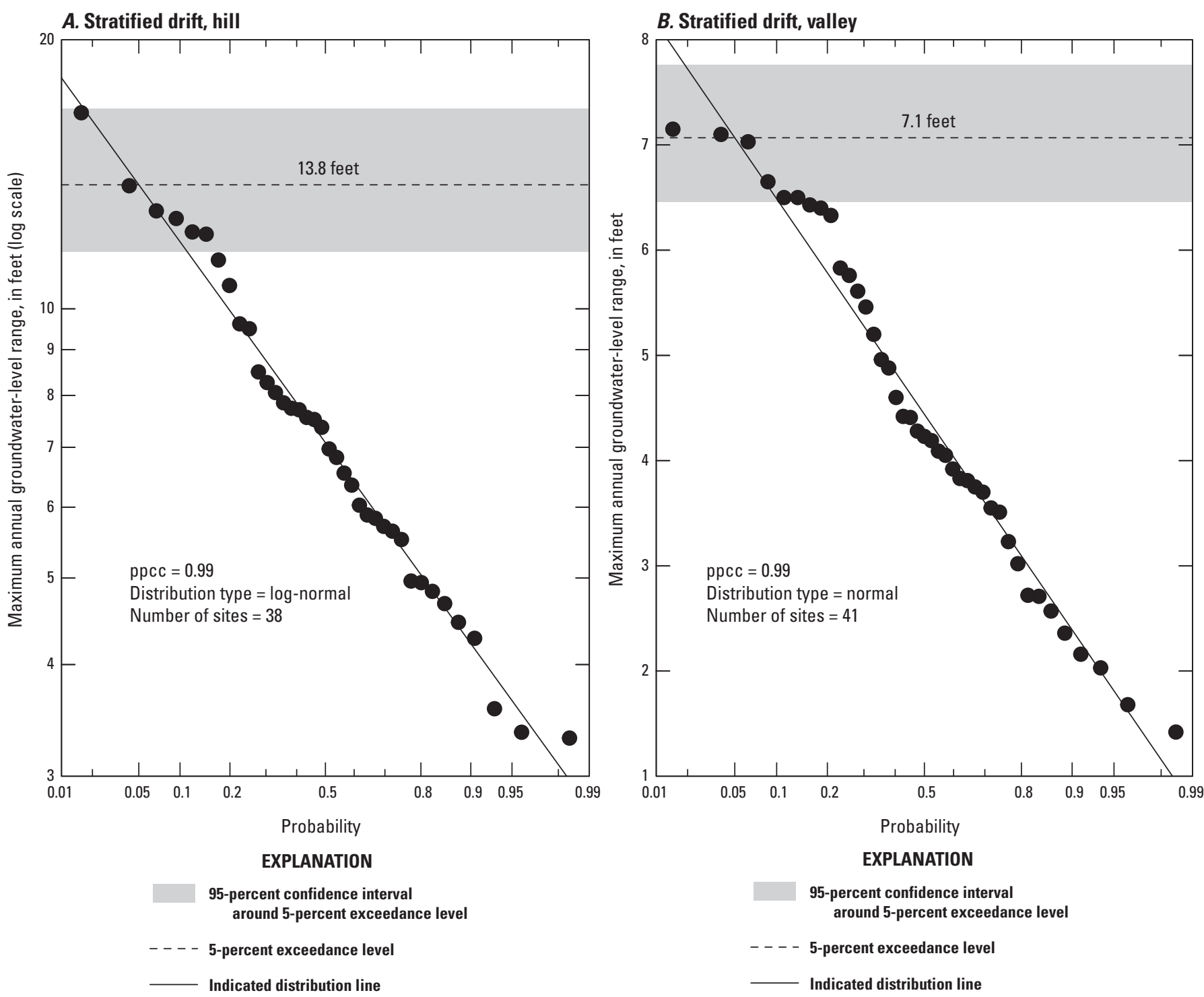

Figure 7. Probability plots of maximum annual groundwater-level ranges for stratified-drift wells in $A$, hill and $B$, valley topographic settings in Massachusetts and surrounding States. The distribution type indicates the type of distribution (normal or log-normal) that was used for estimating the 5-percent exceedance level. The probability-plot correlation coefficient (ppcc) indicates the goodness of fit to the indicated distribution type, where 1 is a perfect fit.

\section{Daily Versus Monthly Data}

Water levels at most wells are measured monthly; however, some wells have automated recorders that measure and transmit water levels at subdaily frequencies (typically 15-minute intervals). Monthly measurements are less costly but might miss extreme high and low water levels, resulting in underestimation of the annual water-level range. Water-level records from a subset of wells with subdaily water-level measurements were analyzed to quantify the within-month variation in water levels that would be missed by monthly measurements and the effects of frequent (daily versus monthly) water-level measurements on calculated annual water-level ranges and high groundwater levels.

\section{Within-Month Variation}

To quantify the within-month variation that might be missed by monthly groundwater-level measurements, the interquartile range of groundwater levels was calculated for each month using the daily mean groundwater level for each site with continuous data. Within-month variability across sites was compared using median monthly interquartile water-level ranges and well and site characteristics (annual groundwaterlevel range, high groundwater level, type of surficial deposits, and topographic setting). In addition, within-month variation across sites was compared for each month. Before the 

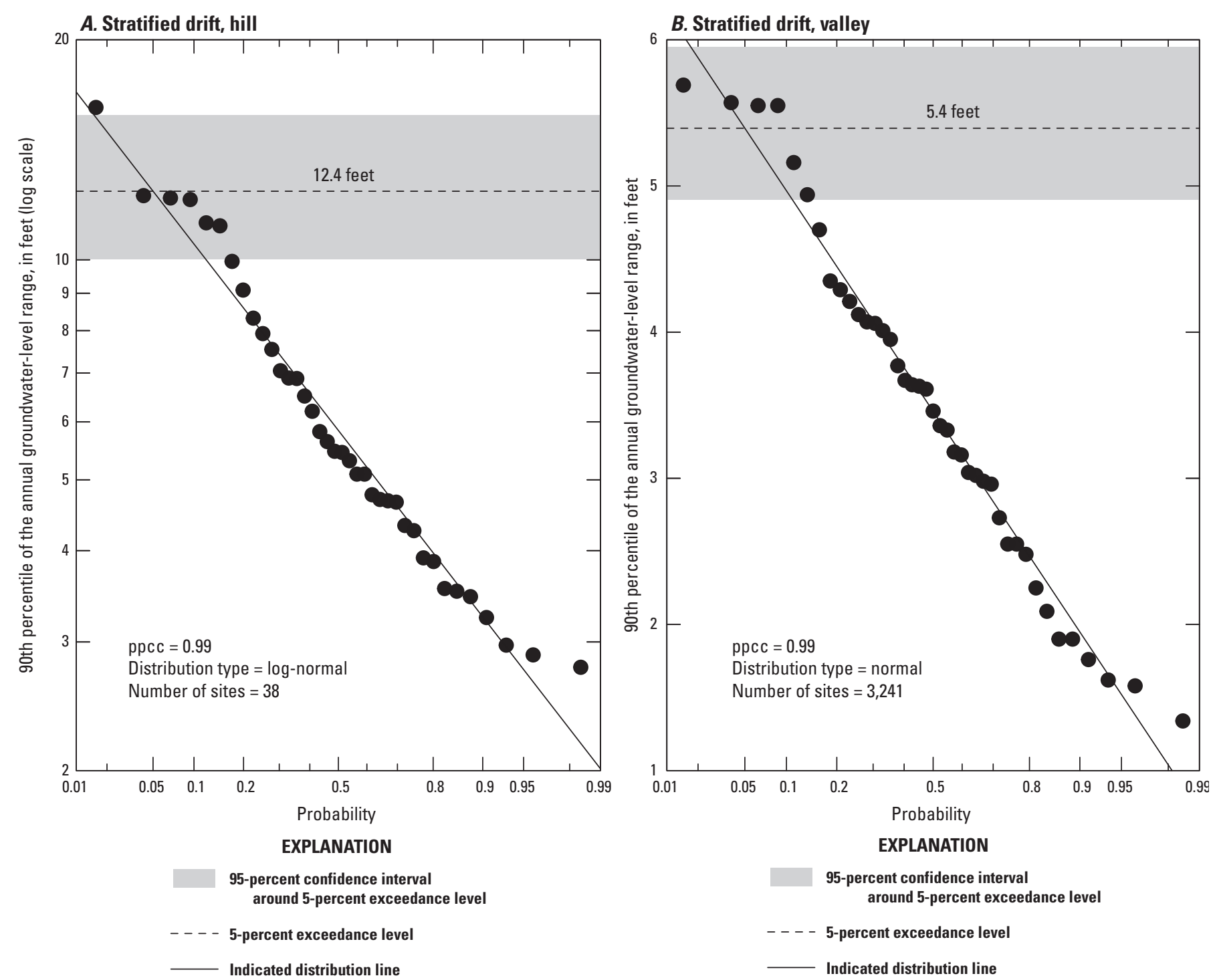

Figure 8. Probability plots of the 90th percentile of annual groundwater-level ranges for stratified drift wells in $A$, hill and $B$, valley topographic settings in Massachusetts and surrounding States. The distribution type indicates the type of distribution (normal or log-normal) that was used for estimating the 5-percent exceedance level. The probability-plot correlation coefficient (ppcc) indicates the goodness of fit to the indicated distribution type, where 1 is a perfect fit.

temporal analysis, the within-month interquartile-range values were standardized by dividing them by the mean monthly interquartile range for each site.

The within-month variation, as indicated by the median monthly interquartile range of water levels, ranged from 0.11 to $0.96 \mathrm{ft}$, with a median of $0.28 \mathrm{ft}$. At the 95 -percent confidence level, the median within-month variation was larger for wells in till than for wells in stratified drift on the mainland or on Cape Cod and the islands, with a median interquartile range for till of $0.64 \mathrm{ft}$, for stratified drift of $0.28 \mathrm{ft}$, and for Cape Cod of $0.16 \mathrm{ft}$ (fig. 9A). Among wells in stratified drift on the mainland, within-month variation in water levels tended to be higher on hills versus in valleys, but the difference in medians was not statistically significant (95-percent confidence; fig. 9B). Larger within-month variation was associated with larger annual groundwater-level ranges ( $($ ho $=0.89$; fig. $10 A$ ), shallower high groundwater levels $($ rho $=-0.55$; fig. $10 B$ ), and larger month-to-month variations (rho $=0.79$; fig. $10 C$ ), as indicated by the interquartile range of mean monthly water levels. Within-month variation tended to be higher in early summer and lower in the fall (fig. 11).

\section{Monthly Versus Daily Mean Groundwater-Level Data}

To quantify the effects of daily versus monthly data on the calculated annual groundwater-level range and high groundwater level, water levels from a subset of 28 wells with 

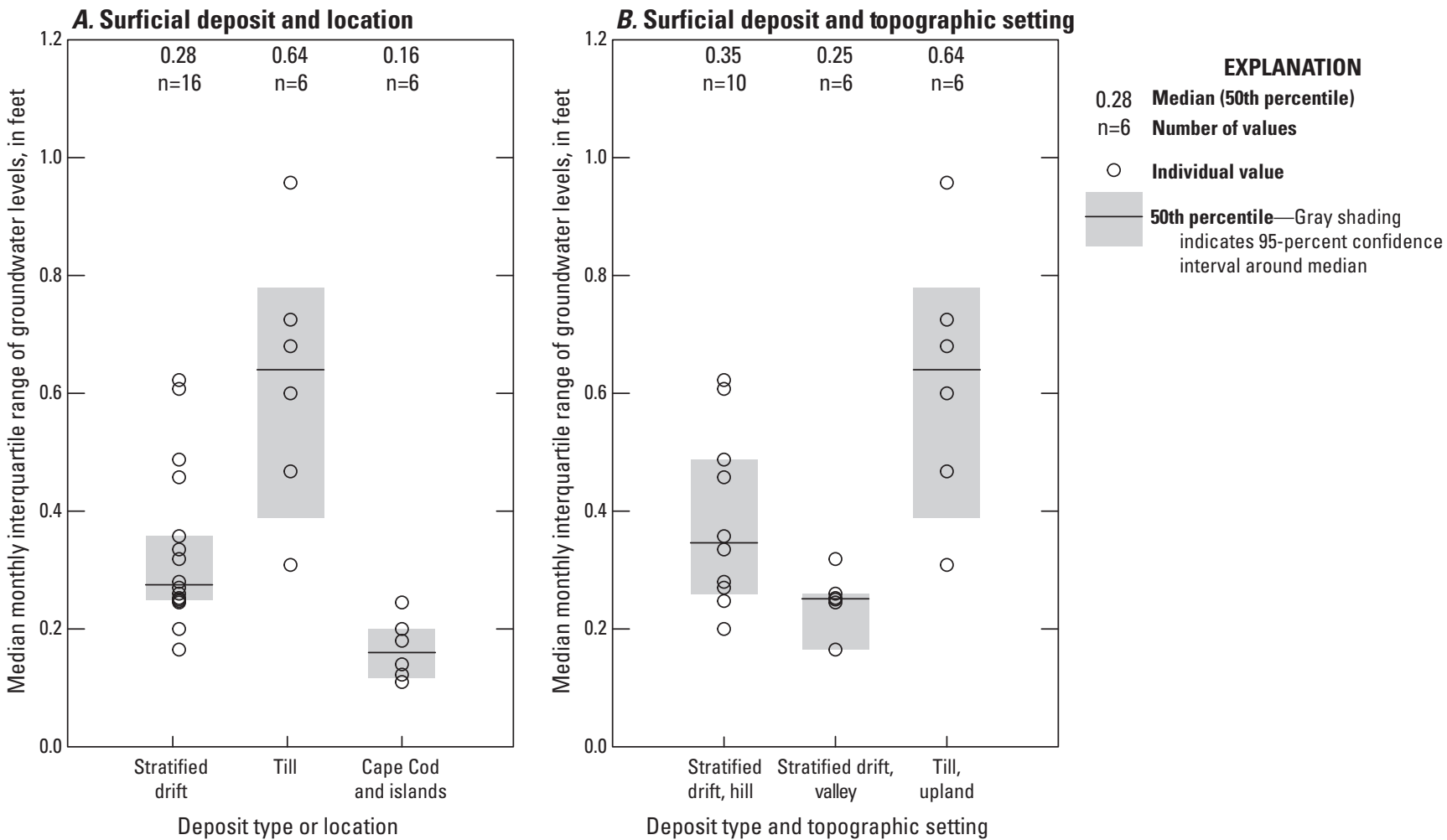

Figure 9. Within-month variation of groundwater levels, as indicated by the interquartile range in water levels, for 28 continuous-record wells in Massachusetts and surrounding States by $A$, surficial deposit and location, and $B$, surficial deposit and topographic setting (does not include wells on Cape Cod or the islands). Boxes are drawn only for more than 20 values.

3 or more water years of continuous (typically hourly) data were analyzed. The daily mean water levels were computed from the continuous data at each site and constituted the daily dataset. For each site, a second monthly dataset for the entire period of continuous data was generated by selecting the daily mean groundwater level from the 25 th day of each month. The high groundwater level and annual groundwater-level range for each water year were calculated using each of the datasets (daily and monthly). The 95-percent confidence intervals around the medians of the distributions of high groundwater levels and annual groundwater-level ranges from the two datasets (daily and monthly) were compared.

Using the daily data from the 28 groundwater observation wells with continuous water-level data resulted in calculated maximum annual groundwater-level ranges that were larger $(0.02$ to $2.94 \mathrm{ft}$ larger, with a median of $0.58 \mathrm{ft})$ and highest recorded groundwater levels that were higher (shallower; 0.00 to $1.60 \mathrm{ft}$ shallower, with a median of $0.18 \mathrm{ft}$ ), than ranges using monthly measurements. These results are similar to what was found in Rhode Island when monthly and 5-day measurements were compared, and monthly measurements were deemed sufficient for estimating high groundwater levels (Socolow and others, 1994). At the 95-percent confidence level, the median change in the calculated maximum annual groundwater-level range was greater for wells on the mainland $(0.90 \mathrm{ft})$ than for wells on Cape Cod and the islands
( $0.1 \mathrm{ft}$; fig. $12 A)$, but there was no difference in the median change between till and stratified-drift wells on the mainland (with 95-percent confidence). At the 95-percent confidence level, the median change in the measured high groundwater level was greater at till sites ( $1.3 \mathrm{ft}$ shallower) than at stratified drift sites $(0.095 \mathrm{ft}$ shallower; fig. 12B), but there was no statistical difference in the median change in measured high groundwater levels between stratified-drift sites on Cape Cod and stratified-drift sites on the mainland. The increase in the calculated range was not correlated with the length of the daily data record $\left(R^{2}=0.046, p=0.14\right)$, but the increase in the high groundwater level was related to the length of the record. For all sites with long records of daily data (15 or more years; $n=10$ ), differences between monthly and daily data records were small for the highest recorded groundwater levels $(0.00$ to $0.45 \mathrm{ft})$. In contrast, the differences between monthly and daily data in shorter records (less than 15 years; $n=18$ ) for sites with daily data ranged from small to large (0.01 to $1.60 \mathrm{ft})$.

At most sites, the shallower high groundwater levels from daily measurements would likely not change the determination of septic-system suitability for the site; however, 3 of the 28 sites had high groundwater levels between 5 and 7 $\mathrm{ft}$ below land surface where small changes in the measured high groundwater level could be important from a regulatory perspective. Even at these sites, however, the difference 

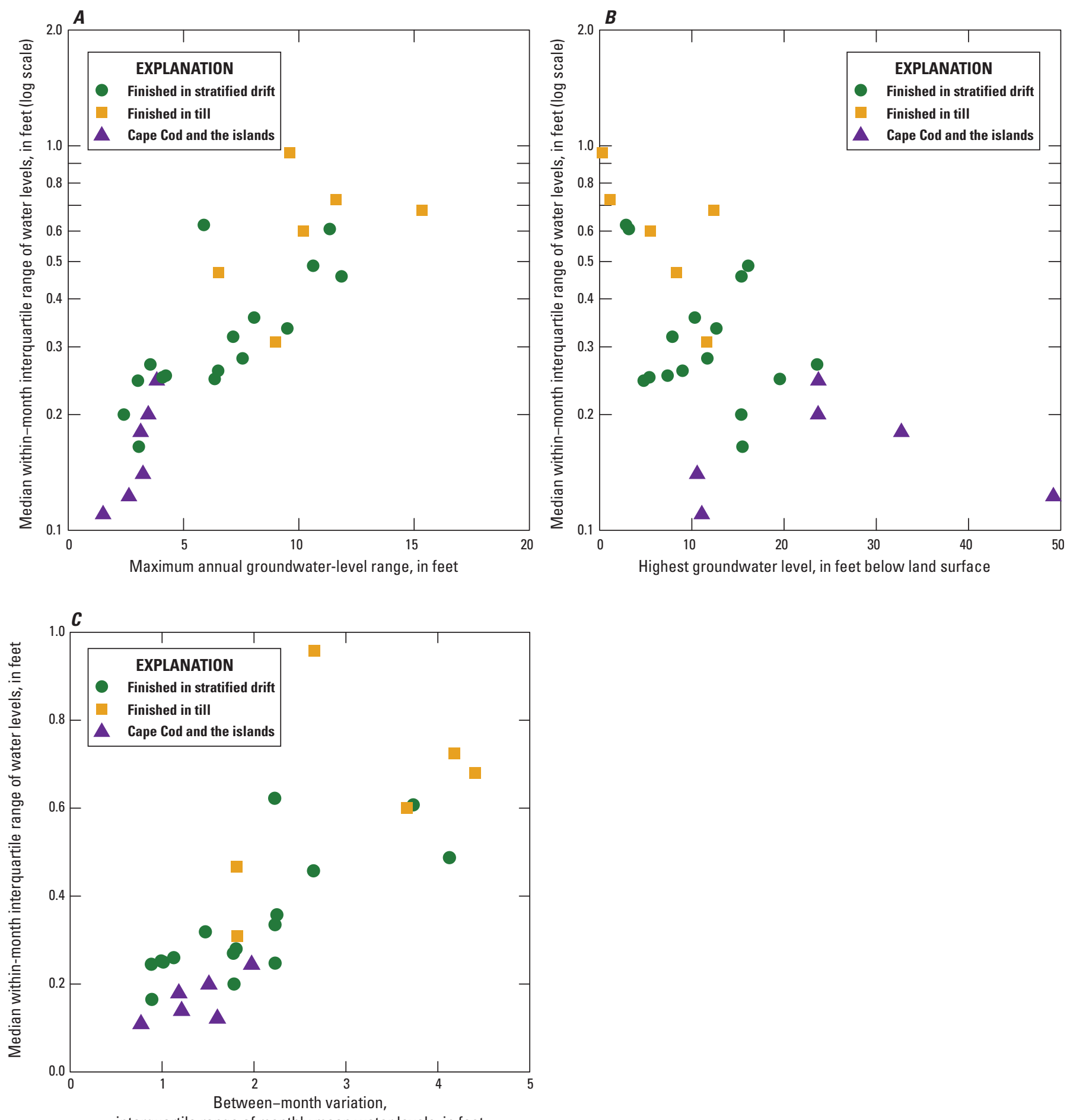

interquartile range of monthly mean water levels, in feet

Figure 10. Within-month variation, as indicated by the interquartile range of water levels within a given month, and groundwater-level extremes for 28 continuous-record wells in Massachusetts and surrounding States. $A$, Medians of the within-month interquartile ranges of groundwater levels versus maximum annual groundwater-level ranges; $B$, within-month interquartile ranges of groundwater levels versus highest recorded groundwater levels.; $\mathrm{C}$, within-month and between-month variation (interquartile range) of water levels for 28 continuous-record wells. 


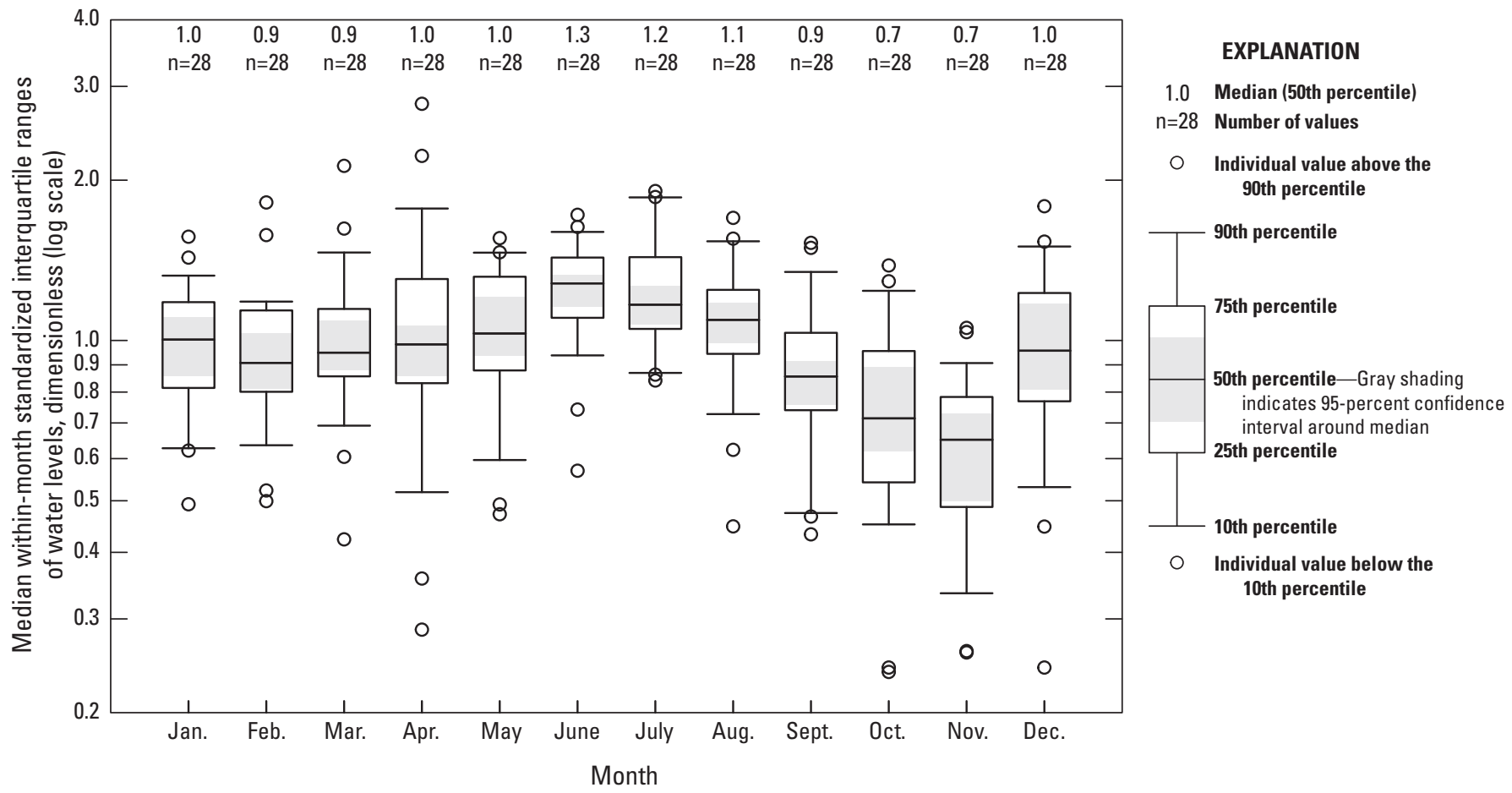

Figure 11. Monthly patterns of within-month variations indicated by the interquartile ranges of water levels for 28 continuous-record wells in Massachusetts and surrounding States.

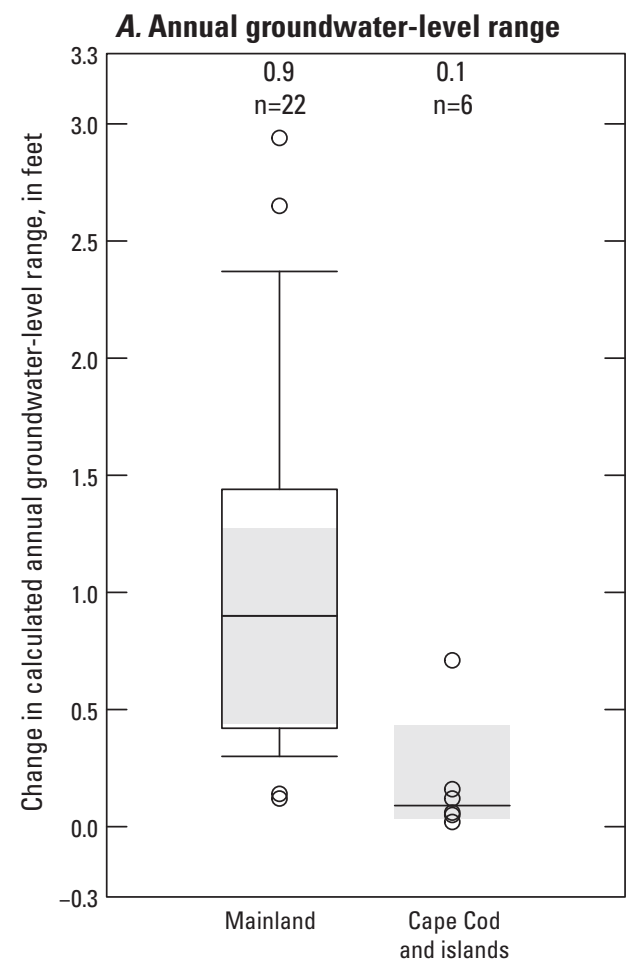

Site location

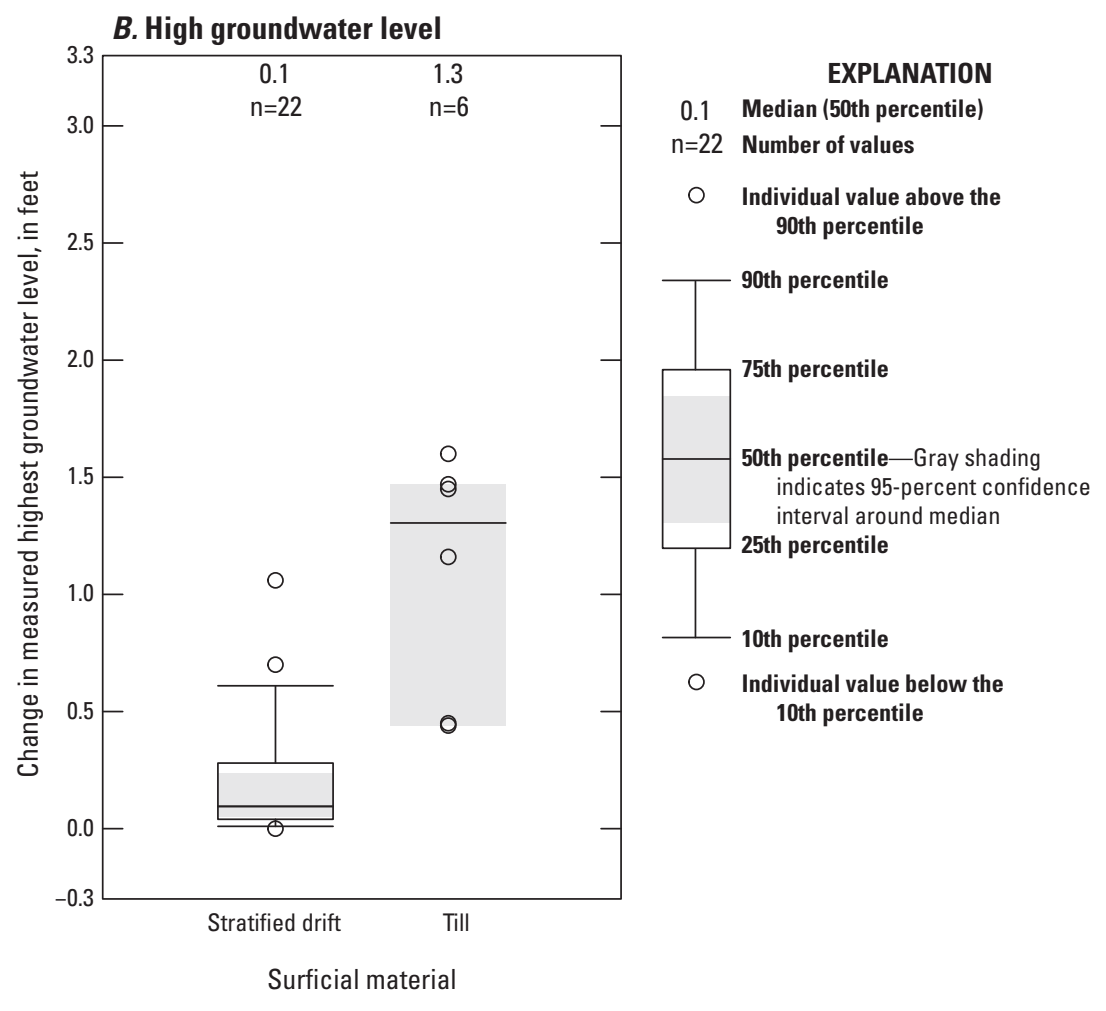

Figure 12. Change in $A$, calculated annual groundwater-level range by well location and $B$, high groundwater level by type of surficial deposit using daily instead of monthly groundwater-level data for 28 wells with continuous groundwater-level records in Massachusetts and surrounding States. Boxes are drawn only for more than 20 values. 
between the high groundwater levels based on daily versus monthly measurements $(0.5 \mathrm{ft})$ is much less than the error in the estimated high groundwater level. These results suggest that monthly water-level measurements are sufficient for determining the distribution of annual groundwater levels, the maximum recorded groundwater level, and the annual groundwater-level range at index wells. Water levels can rise quickly in response to large rain events; therefore, if continuous data are available, they should be used for determining the water level at the index well at the time of the measurement at the test site (OWc for eqs. 1 and 2).

\section{Long-Term Trends in Water Levels}

Trends in high groundwater levels, low groundwater levels, and annual groundwater-level ranges were quantified to provide guidance on the need to account for trends in estimates of high groundwater levels.

\section{Trend-Analysis Methods}

Potential long-term trends in high groundwater, low groundwater, and annual groundwater-level ranges were identified using Kendall's nonparametric test for a monotonic trend as implemented in the EnvStats package in R (Millard, 2013; $\mathrm{R}$ Core Team, 2018). Trends in the annual high groundwater level, annual low groundwater level, and annual groundwaterlevel ranges as well as trends in groundwater levels for each month were computed. Each possible trend was classified on a likelihood scale (table 1) ranging from no trend to very likely using the confidence level of the Kendall test and the trendclassification criteria in Hirsch and others (2015).

Trends were analyzed over six periods (water years): 1966-2015, 1986-2015, 1996-2015, 1966-1985, 1991-2010, and 1981-2010 (table 2). These periods were selected based on data availability and to facilitate comparison with Dudley and Hodgkins (2013), who evaluated trends in groundwater levels in New England. When daily mean groundwater-level data were available, the daily mean from the 25 th day of each month was used; otherwise, the closest measurement within 7 days of the 25 th day of each month was used. Measurements not within 7 days of the 25 th day of each month were removed before analysis. All sites included in the monthly groundwatertrend analysis had at least 9 of 12 monthly values for 8 of every 10 water years for each of the 10-year analysis periods (Dudley and Hodgkins, 2013). Wells on Cape Cod and the islands were included in this analysis.

\section{Trend-Analysis Results}

The highest annual groundwater levels (the shallowest groundwater levels in specific water years) showed moderate to strong statistical support (likely or very likely) for the presence of a trend towards higher (shallower) high groundwater levels at most wells during most of the six periods (figs. $13 A$ and $14 A$; table 3 ). For wells and periods with trends to higher groundwater, the medians of the trend magnitudes for the periods ranged from -0.078 to -0.019 feet per year ( $\mathrm{ft} / \mathrm{yr}$ ), where negative values indicate an upward trend (table 3 ), with smaller rates of increasing water levels during the longer test periods. Notable exceptions occurred during the periods from 1996 through 2015 and 1966 through 1985 (fig. 14A), when most wells had no trend.

Low groundwater levels (the deepest groundwater level during the water year; fig. 13B) were trending higher (at shallower depths) at many wells during most of the six periods evaluated, but the pattern was less widespread than for high groundwater levels (figs. $13 A-B$ and $14 A-B$; table 4), and a larger number of wells had trends to deeper low groundwater levels. In wells and during periods with trends to higher low groundwater (when the deepest groundwater level during the year was closer to the land surface), the magnitudes of the median trends for the period ranged from -0.012 to $-0.065 \mathrm{ft} / \mathrm{yr}$ (table 4). In wells and periods with trends to deeper low groundwater, the magnitudes of the median trends for the period ranged from 0.016 to $0.032 \mathrm{ft} / \mathrm{yr}$. Similar to high groundwater levels, the periods of 1996 through 2015 and 1966 through 1995 (fig. 14B) were notable exceptions.

There was no clear pattern in trends of annual groundwater-level ranges (figs. $13 C$ and $14 C$; table 5). The trends that did exist tended to be towards larger annual groundwater-level ranges. These trends might be a result of shallower high groundwater levels, deeper low groundwater levels, or both.

There was no clear pattern in the trends of monthly groundwater levels (fig. 15). Very few sites had trends to deeper groundwater levels for any month during any of the periods, but the remainder of sites were relatively evenly split between no trends and trends to shallower groundwater.

Table 1. Confidence levels and corresponding trend-likelihood descriptions.

[Modified from Hirsch and others (2015)]

\begin{tabular}{|c|c|}
\hline Confidence level & Description \\
\hline Greater than or equal to 90 percent & Very likely \\
\hline Greater than or equal to 67 percent and less than 90 percent & Likely \\
\hline
\end{tabular}


Table 2. Periods used in the trend analysis of groundwater levels for U.S. Geological Survey observation wells in Massachusetts and surrounding States.

\begin{tabular}{ccccc}
\hline Trend period & Starting water year & Ending water year & Number of water years & Number of wells \\
\hline 1 & 1966 & 1985 & 20 & 57 \\
2 & 1981 & 2010 & 30 & 29 \\
3 & 1986 & 2015 & 30 & 18 \\
4 & 1991 & 2010 & 20 & 40 \\
5 & 1996 & 2015 & 20 & 26 \\
6 & 1966 & 2015 & 50 & 14 \\
\hline
\end{tabular}

Overall, groundwater levels remained unchanged or trended higher (shallower) at most sites, with the annual groundwater-level ranges showing no trends. Trends to higher high and low groundwater levels were consistent with what Dudley and Hodgkins (2013) found for northern New England, but Dudley and Hodgkins (2013) also found trends to increasing groundwater-level ranges. The trends toward shallower groundwater levels could indicate that septic drainage fields close to the high groundwater level that do not currently [2020] flood may flood in the decades to come.

\section{Evaluating and Implementing the Method}

Application of the Frimpter method requires the user to estimate the annual groundwater-level range at the site of interest and select an appropriate index well. In the original method (Frimpter, 1981), the annual groundwater-level range was estimated from a probability distribution of maximum annual groundwater-level ranges from available well data, and minimal guidance was given regarding selection of an index well. In addition, the estimated high groundwater levels in Frimpter (1981) were not compared with known high groundwater levels to evaluate the accuracy of the method. In this study, the accuracy of the method was assessed using three approaches to estimate the annual groundwater-level range and six approaches to select an index well to provide improved implementation guidance.

\section{Test Measurements}

The first step in estimating the high groundwater level at a site was to take a test measurement of the current depth to water. To evaluate the ability of the method to estimate probable high groundwater levels, each well was treated as a test site, and the predicted high-water level was calculated using "test measurements" that were selected from a range of hydrologic conditions in the historical record. The predicted high groundwater levels were then compared with observed values. To select test-measurement dates, the groundwater-level record for each well was first divided into five groups based on water levels: high, slightly high, midrange, slightly low,

Table 3. Magnitudes and directions of trends in annual high groundwater levels in wells in Massachusetts and surrounding States for six periods.

[Trends are significant at the 67-percent confidence level. $\mathrm{ft} / \mathrm{yr}$, foot per year]

\begin{tabular}{|c|c|c|c|c|c|c|c|c|c|}
\hline \multirow{2}{*}{$\begin{array}{l}\text { Period } \\
\text { (water } \\
\text { years) }\end{array}$} & \multirow{2}{*}{$\begin{array}{c}\text { Number } \\
\text { of } \\
\text { years }\end{array}$} & \multirow{2}{*}{$\begin{array}{c}\text { Number } \\
\text { of } \\
\text { wells }\end{array}$} & \multirow{2}{*}{$\begin{array}{l}\text { No trend, } \\
\text { percentage } \\
\text { of sites }{ }^{1}\end{array}$} & \multicolumn{3}{|c|}{ Shallower² } & \multicolumn{3}{|c|}{ Deeper² } \\
\hline & & & & $\begin{array}{c}\text { Percentage } \\
\text { of sites } 1\end{array}$ & Range, ${ }^{3}$ in $\mathrm{ft} / \mathrm{yr}$ & $\begin{array}{l}\text { Median, } \\
\text { in ft/yr }\end{array}$ & $\begin{array}{c}\text { Percentage } \\
\text { of sites } 1\end{array}$ & Range, 3 in ft/yr & $\begin{array}{c}\text { Median, } \\
\text { in ft/yr }\end{array}$ \\
\hline $1966-2015$ & 50 & 14 & 29 & 64 & -0.054 to -0.0073 & -0.019 & 7 & 0.013 & 0.013 \\
\hline 1981-2010 & 30 & 29 & 31 & 62 & -0.21 to -0.015 & -0.047 & 7 & 0.012 to 0.08 & 0.046 \\
\hline 1996-2015 & 20 & 26 & 73 & 15 & -0.12 to -0.017 & -0.064 & 12 & 0.026 to 0.061 & 0.034 \\
\hline
\end{tabular}

1Percentages were rounded so totals add up to 100 percent.

${ }^{2}$ Shallower and deeper indicate directions of trends in high groundwater levels, with shallower indicating direction toward the land surface.

${ }^{3}$ Range indicates the range in trend magnitude across sites with a given trend direction. 

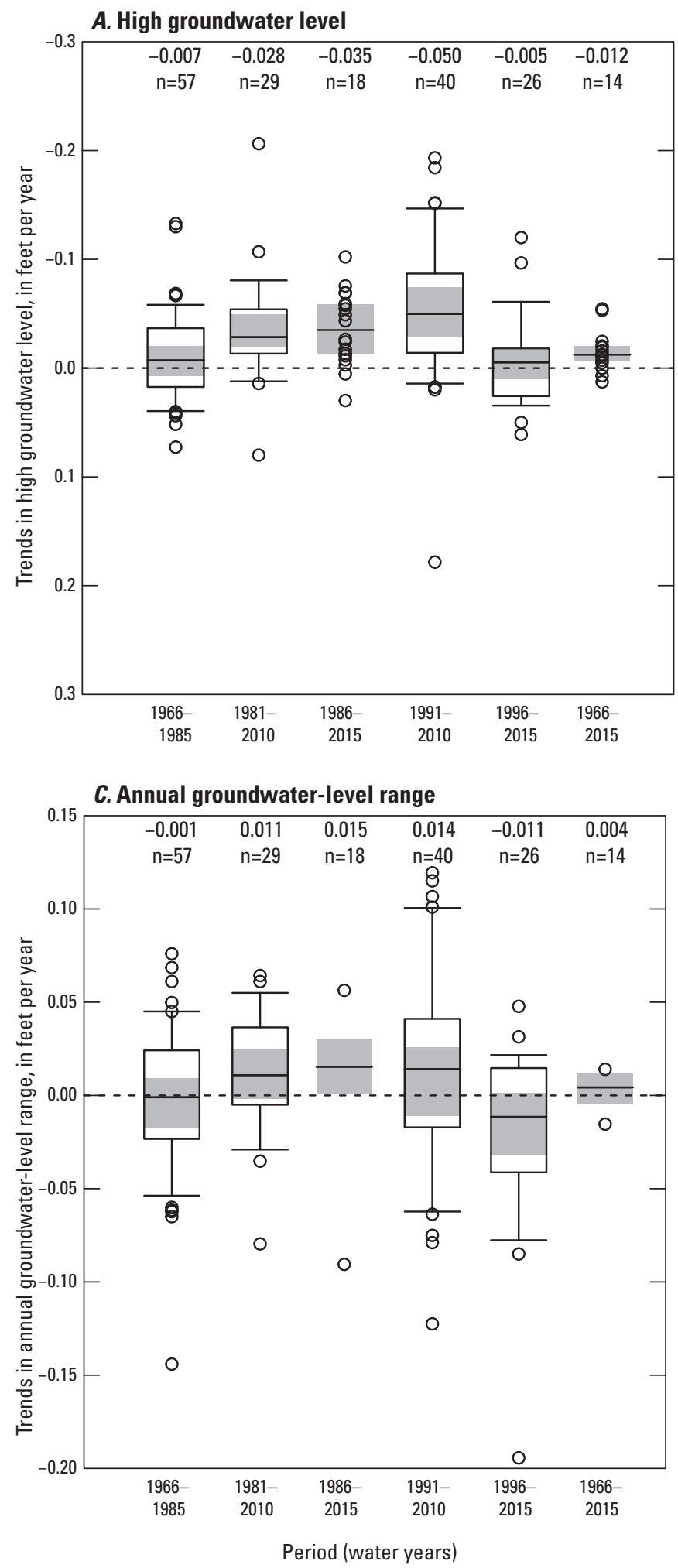

$B$. Low groundwater level

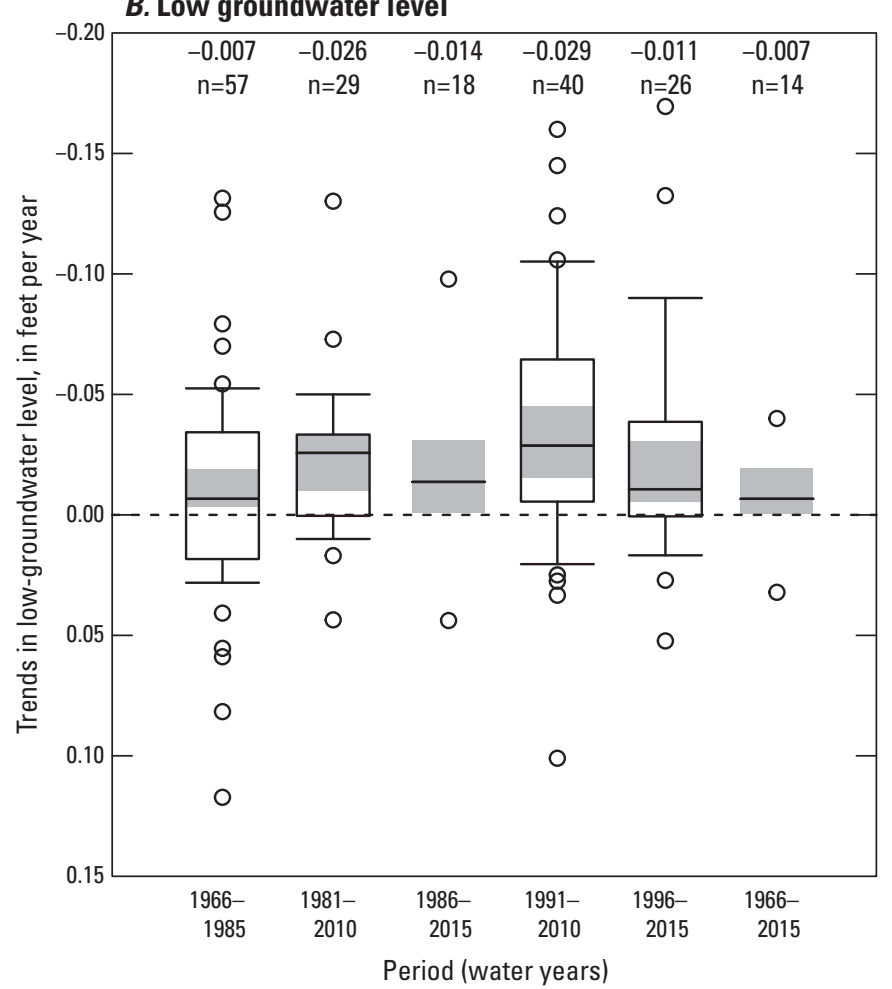

Figure 13. Magnitudes of trends in $A$, high groundwater-level, $B$, low groundwater-level, and $C$, annual (water-year) groundwater-level ranges for six periods for wells in Massachusetts and surrounding States. For high and low groundwater levels, negative values indicate an upward trend. Boxes are drawn only for more than 20 values. 
A. High groundwater level

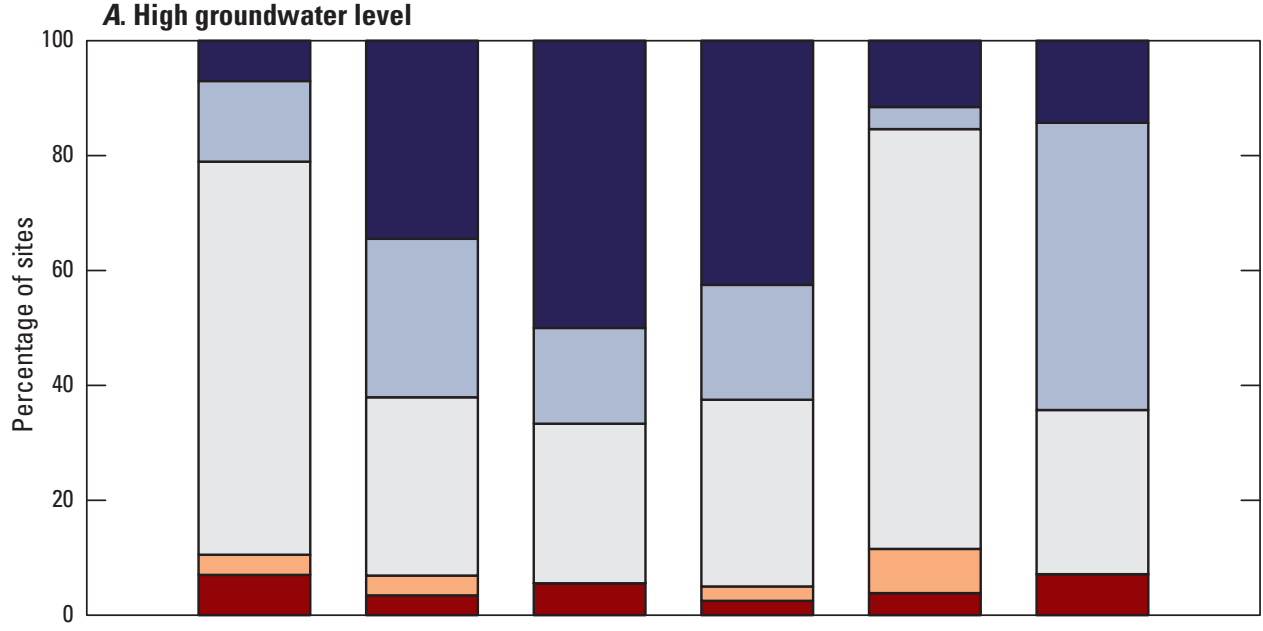

EXPLANATION

Very likely increasing

Likely increasing

\section{No trend}

Likely decreasing

Very likely decreasing
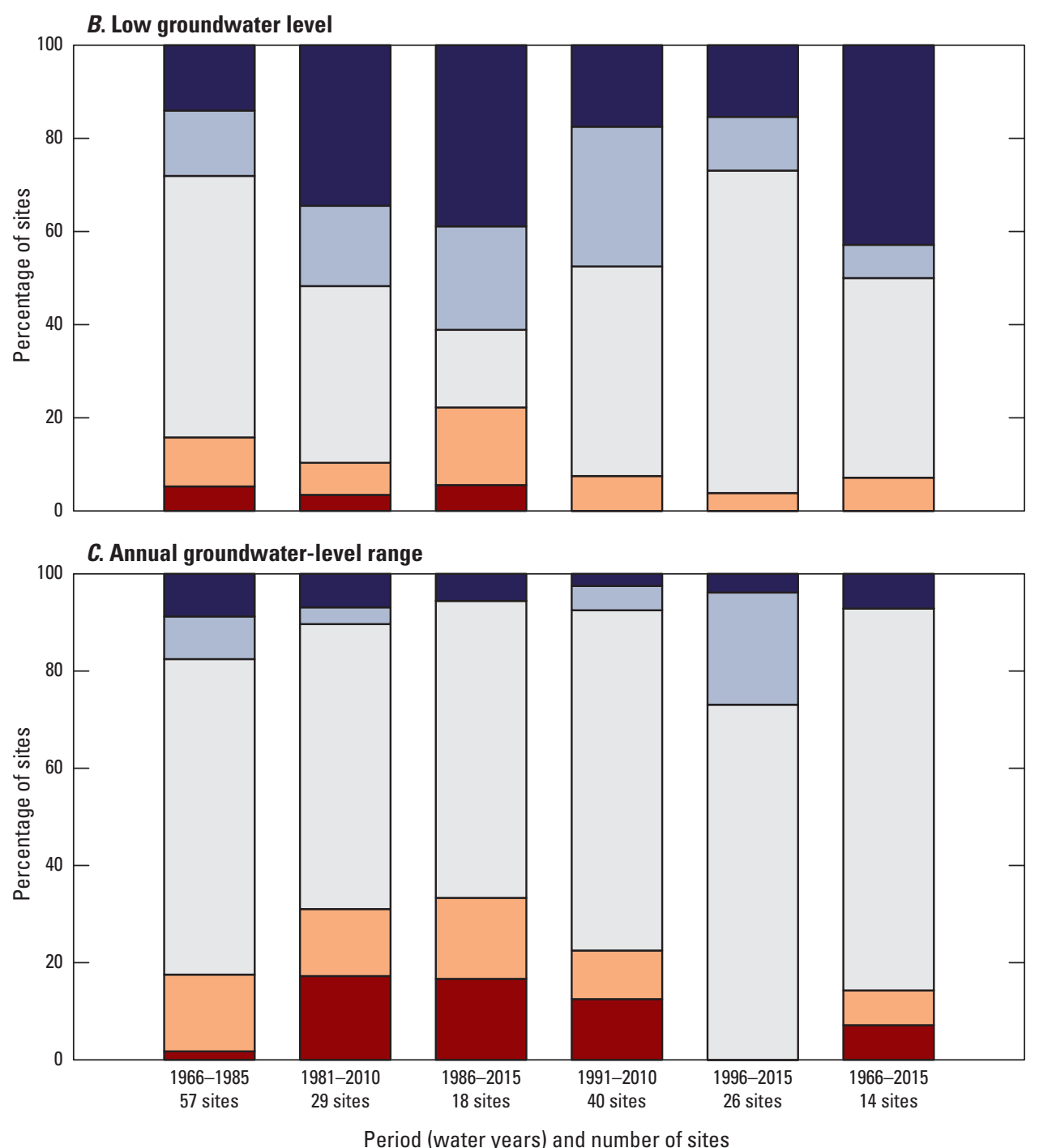

Figure 14. Likelihoods of trends in $A$, high groundwater, $B$, low groundwater, and $C$, annual groundwater-level ranges during six periods for wells in Massachusetts and surrounding States. 
Table 4. Magnitudes of trends in annual low groundwater levels in wells in Massachusetts and surrounding States for six periods.

[Trends are significant at the 67-percent confidence level. $\mathrm{ft} / \mathrm{yr}$, foot per year]

\begin{tabular}{|c|c|c|c|c|c|c|c|c|c|}
\hline \multirow{2}{*}{$\begin{array}{l}\text { Period } \\
\text { (water } \\
\text { years) }\end{array}$} & \multirow{2}{*}{$\begin{array}{l}\text { Number } \\
\text { of years }\end{array}$} & \multirow{2}{*}{$\begin{array}{l}\text { Number } \\
\text { of wells }\end{array}$} & \multirow{2}{*}{$\begin{array}{c}\text { No trend, } \\
\text { percentage } \\
\text { of sites }{ }^{1}\end{array}$} & \multicolumn{3}{|c|}{ Shallower² } & \multicolumn{3}{|c|}{ Deeper $^{2}$} \\
\hline & & & & $\begin{array}{l}\text { Percentage } \\
\text { of sites } 1\end{array}$ & Range, ${ }^{3}$ in $\mathrm{ft} / \mathrm{yr}$ & $\begin{array}{c}\text { Median, in } \\
\mathrm{ft} / \mathrm{yr}\end{array}$ & $\begin{array}{l}\text { Percentage } \\
\text { of sites } 1\end{array}$ & Range, ${ }^{3}$ in ft/yr & $\begin{array}{c}\text { Median, } \\
\text { in ft/yr }\end{array}$ \\
\hline 1966-1985 & 20 & 57 & 56 & 28 & -0.13 to -0.0075 & -0.041 & 16 & 0.01 to 0.12 & 0.028 \\
\hline 1966-2015 & 50 & 14 & 43 & 50 & -0.04 to -0.0039 & -0.012 & 7 & 0.032 to 0.032 & 0.032 \\
\hline 1981-2010 & 30 & 29 & 38 & 52 & -0.13 to -0.01 & -0.032 & 10 & 0.0082 to 0.044 & 0.017 \\
\hline 1986-2015 & 30 & 18 & 17 & 61 & -0.098 to -0.012 & -0.028 & 22 & 0.01 to 0.044 & 0.017 \\
\hline 1991-2010 & 20 & 40 & 45 & 47 & -0.16 to -0.021 & -0.065 & 8 & 0.0088 to 0.1 & 0.016 \\
\hline 1996-2015 & 20 & 26 & 69 & 27 & -0.17 to -0.018 & -0.039 & 4 & 0.027 to 0.027 & 0.027 \\
\hline
\end{tabular}

1 Percentages were rounded so totals add up to 100 percent.

2Shallower and deeper indicate directions of trends in high groundwater levels, with shallower indicating direction toward the land surface.

${ }^{3}$ Range indicates the range in trend magnitude across sites with a given trend direction.

Table 5. Magnitudes of trends in annual groundwater-level ranges for six periods for wells in Massachusetts and surrounding States.

[Trends are significant at the 67-percent confidence level. $\mathrm{ft} / \mathrm{yr}$, foot per year]

\begin{tabular}{|c|c|c|c|c|c|c|c|c|c|}
\hline \multirow{2}{*}{$\begin{array}{l}\text { Period } \\
\text { (water } \\
\text { years) }\end{array}$} & \multirow{2}{*}{$\begin{array}{l}\text { Number } \\
\text { of years }\end{array}$} & \multirow{2}{*}{$\begin{array}{l}\text { Number } \\
\text { of wells }\end{array}$} & \multirow{2}{*}{$\begin{array}{c}\text { No trend, } \\
\text { percentage } \\
\text { of sites }^{1}\end{array}$} & \multicolumn{3}{|c|}{ Smaller ${ }^{2}$} & \multicolumn{3}{|c|}{ Larger $^{2}$} \\
\hline & & & & $\begin{array}{l}\text { Percentage } \\
\text { of sites }{ }^{1}\end{array}$ & Range, ${ }^{3}$ in $\mathrm{ft} / \mathrm{yr}$ & $\begin{array}{c}\text { Median, } \\
\text { in } \mathrm{ft} / \mathrm{yr}\end{array}$ & $\begin{array}{c}\text { Percentage } \\
\text { of sites }{ }^{1}\end{array}$ & Range $^{3}$ in $\mathrm{ft} / \mathrm{yr}$ & $\begin{array}{c}\text { Median, } \\
\text { in } \mathrm{ft} / \mathrm{yr}\end{array}$ \\
\hline 1966-1985 & 20 & 57 & 64 & 18 & -0.14 to -0.017 & -0.056 & 18 & 0.024 to 0.076 & 0.044 \\
\hline 1966-2015 & 50 & 14 & 79 & 7 & -0.015 to -0.015 & -0.015 & 14 & 0.01 to 0.013 & 0.012 \\
\hline 1981-2010 & 30 & 29 & 59 & 10 & -0.08 to -0.018 & -0.029 & 31 & 0.021 to 0.064 & 0.044 \\
\hline 1986-2015 & 30 & 18 & 61 & 6 & -0.091 to -0.091 & -0.091 & 33 & 0.03 to 0.056 & 0.04 \\
\hline 1991-2010 & 20 & 40 & 70 & 8 & -0.058 to -0.034 & -0.035 & 22 & 0.038 to 0.12 & 0.06 \\
\hline 1996-2015 & 20 & 26 & 73 & 27 & -0.19 to -0.026 & -0.073 & 0 & No sites with $t$ & is trend \\
\hline
\end{tabular}

1Percentages were rounded so totals add up to 100 percent.

${ }^{2}$ Smaller and larger indicate direction of trend in annual groundwater-level ranges.

${ }^{3}$ Range refers to the trend magnitude across sites with a given trend direction.

and low (each group with 20 percent of the record). Then, five dates from the preceding 5 years (water years 2013-17) were randomly selected from each water-level group, for a maximum total of 25 test dates for each well. The ranges of water levels in some wells were not complete during water years 2013-17, and some estimates for these wells were missing. For each test date, the most probable high groundwater level was then calculated using the approaches described in the following section for estimating the annual groundwater-level range and selecting an index well; then the calculated value was compared with groundwater-level measurements.

\section{Approaches To Estimating the Annual Groundwater-Level Range}

The second step in estimating the high groundwater level was to estimate the annual groundwater-level range. Three potential approaches to estimating the annual groundwaterlevel range were compared. The approaches included (1) the original method (Frimpter, 1981), which uses the 5-percent exceedance probability from the distribution of maximum annual groundwater-level ranges at index sites in similar surficial deposits and topographic settings, (2) use of the 5-percent exceedance probability from a distribution of the 90th percentile of annual groundwater-level ranges from the same groups of index wells, and (3) estimation of the annual groundwaterlevel range (either the maximum or the 90th percentile) using two test measurements taken during differing hydrologic conditions. Because the test sites (study wells) were also used 

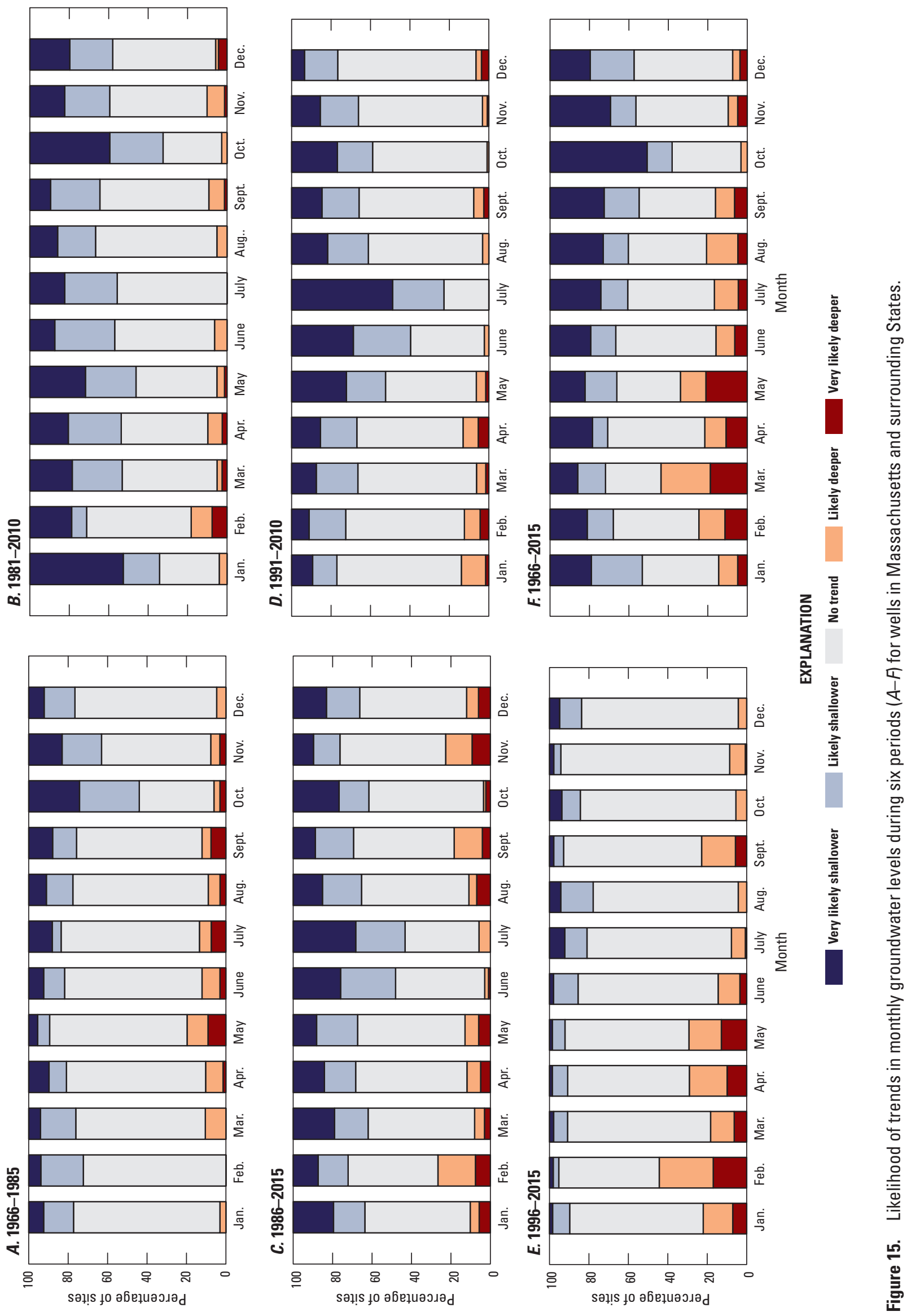
to create the maximum and 90th-percentile distributions, the 5 -percent exceedance probability was recalculated for each test site using measurements from all wells in the appropriate surficial-deposit and topographic settings except for the test well.

Using a distribution of the 90th percentile of annual groundwater-level ranges may better represent typical conditions because extreme outliers would be removed from the distribution. When the range was estimated from this distribution, the 90th percentile annual groundwater-level range and high groundwater level at the index well were also used to determine the values represented by $O W r$ and $O W m a x$ (eqs. 1 and 2).

Using two test measurements to estimate the annual water-level range could improve the estimate: the change in water level between the two dates at the test site could be compared with the change in water level between the same two dates at a well with a known annual water-level range. For this approach, the ratio of the change in water levels between two test dates at the test site to the change in water levels between the same two test dates at the index well was assumed to be equal to the ratio of the water-level range at the test site to the water-level range at the index well. To test this assumption, groundwater levels at the test well and the index well were divided into five groups by water level, and the date selected was the date nearest the original test date when the water levels at both the index well and the test well changed in the same direction by two or more water-level groups. The following equation was used to estimate the annual groundwater-level range at the test well for this alternative approach:

$$
\frac{S r}{O W r}=\frac{S c-S c 2}{O W c-O W c 2}
$$

where

Sc2 is the water level at the test site on the second test day, and

$O W c 2$ is the water level at the index well on the second test day.

\section{Identifying the Topographic Setting of a Test Site}

Estimating the annual groundwater-level range based on the 5-percent exceedance probability requires the user to identify the topographic setting of the test sites. For the purposes of this study, wells in glacial till were divided into two groups based on topographic setting: near-stream and upland. Near-stream was defined as within $328 \mathrm{ft}$ (100 meters [m]) horizontally and $16 \mathrm{ft}(5 \mathrm{~m})$ vertically of the nearest stream based on analysis of patterns in groundwater levels and annual groundwater-level ranges. All other wells in glacial till were considered upland. Wells in stratified drift were also divided into two groups: hill and valley. These classifications were based on the inspection of a topographic map. Because groundwater was deeper beneath sites in hill settings than in valley settings, the groundwater level can be used as a secondary indicator of the likely topographic setting (fig. 16).

\section{Comparison of Range Estimates}

The maximum and 90th-percentile annual groundwaterlevel ranges estimated from the 5-percent exceedance probability and the two-measurement approach were compared with the known maximum and 90th-percentile annual groundwaterlevel ranges at each site. The accuracy of the range estimates was assessed using the mean error, mean absolute error, and the percentage of measurements for which the annual groundwater-level range was underestimated by 20 percent or more. The mean error reflects the potential bias of the method, and the mean absolute error reflects the magnitude of the errors. Underestimating the annual groundwater-level range is a problem because it will lead to deeper estimated high groundwater levels and, as a result, a potentially incorrect determination that a site is suitable for an unmounded ${ }^{4}$ septic system.

In all approaches to estimating the annual groundwaterlevel range, the mean error was positive, indicating that, in general, the estimated annual groundwater-level range at a given site is likely to be greater than the actual range. This is a result of using the 5-percent exceedance-probability value for the range (a value that is expected to be exceeded in only 5 percent of wells) and leads to a conservative determination of the suitability of the site for an unmounded septic system. The mean errors for the maximum and 90th-percentile annual groundwater-level ranges were greater when the error was estimated using the 5-percent exceedance probability than when the range was estimated using two test measurements (fig. 17A). The larger positive mean error with the exceedance approach indicates that it is biased towards estimating largerthan-actual annual groundwater-level ranges. In contrast to the mean error, the mean absolute error was substantially higher for wells in glacial till when the maximum and 90th-percentile annual groundwater-level ranges were calculated using the two-measurement approach (fig. 17B). This result indicates that the two-measurement approach to estimating the annual groundwater-level range results in large errors (overestimation and underestimation) in some wells in glacial till. In wells in stratified drift, the mean absolute error was greater with the 5-percent exceedance-probability approach than with the two-measurement approach because of the bias of the exceedance approach (as indicated by the similar magnitude of the mean error and the mean absolute error for wells in stratified drift). Finally, the percentage of wells for which the annual groundwater-level range was underestimated by 25 percent or more was much higher when the range was estimated using two measurements than when the 5-percent exceedance

\footnotetext{
${ }^{4} \mathrm{~A}$ mounded system is one where a septic drainage field is built above the existing land surface to allow the necessary vertical separation between the high groundwater level and the bottom of the drainage field.
} 


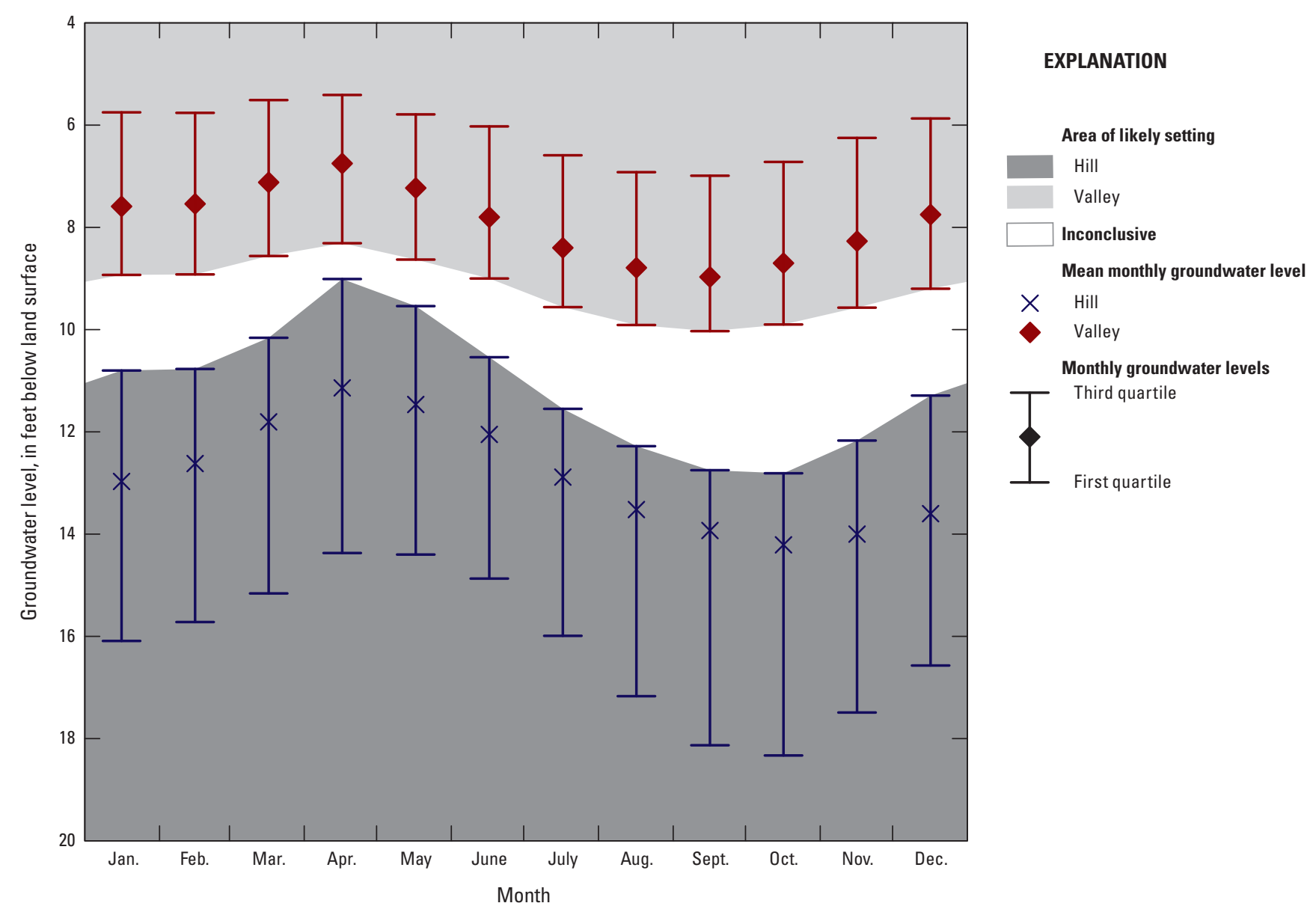

Figure 16. Mean monthly groundwater levels in wells in stratified-drift deposits in hill and valley topographic settings. To use this figure to estimate the topographic setting of a well located in stratified-drift deposits, plot the current groundwater level over the current month. If the groundwater level plots within the light gray region at the top, the site is likely (with greater than 75-percent confidence) to be in a valley setting. If the groundwater level is plotted within the darker gray region at the bottom, it is likely (with greater than 75-percent confidence) to be in a hill setting. Topographic settings based on water levels that are plotted in the white region are inconclusive.

probability approach was used (fig. 17C). This underestimation may be the most important metric because it could lead to an incorrect determination of suitability for an unmounded septic system and ultimately to septic-system failure.

\section{Approaches to Selecting an Index Well}

The third step of the method is the selection of an appropriate index well. The selection of the index well is based on the assumption that water levels at the index well respond similarly to water levels at the test site, that is, that they are highly correlated. Six approaches to selecting an index well were considered: (1) random and in any surficial deposit, (2) random and in the same surficial deposits as the test site, (3) random and in the same topographic setting and surficial deposits as the test site, (4) nearest geographic distance and in the same surficial deposits as the test site, (5) most similar water level in depth below land surface at the time of the test measurement and in the same surficial deposits as the test site, and (6) a predictive equation.

\section{Correlations Between Wells}

In preparation for evaluating the approaches to selecting an index well, correlations between all pairs of wells were calculated using Spearman's rho (Helsel and Hirsch, 2002) with a pairwise comparison (U.S. Geological Survey, 2015). Higher correlations between two wells indicate that water levels in the wells change at the same times and in the same directions (deeper or shallower), although the actual magnitudes of the water-level changes may differ between the wells. Correlations (Spearman's rho) between water levels in all well pairs ranged from -0.08 to 0.98 , with a median of 0.66 . Correlations were higher between well pairs of all types finished in the same topographic group (including surficial deposits), at a similar 


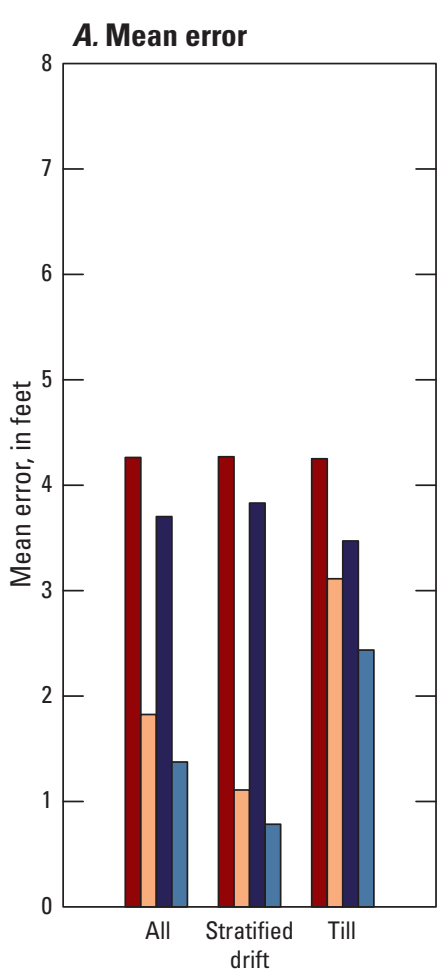

Surficial deposit type

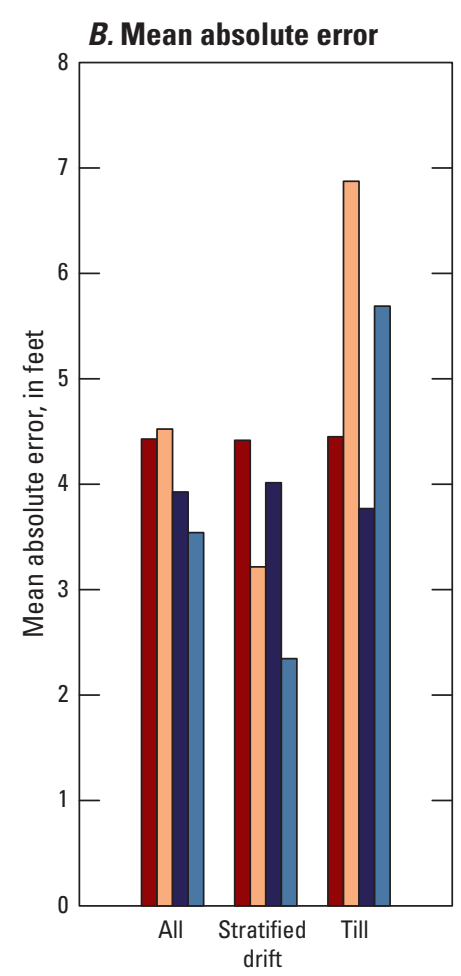

Surficial deposit type

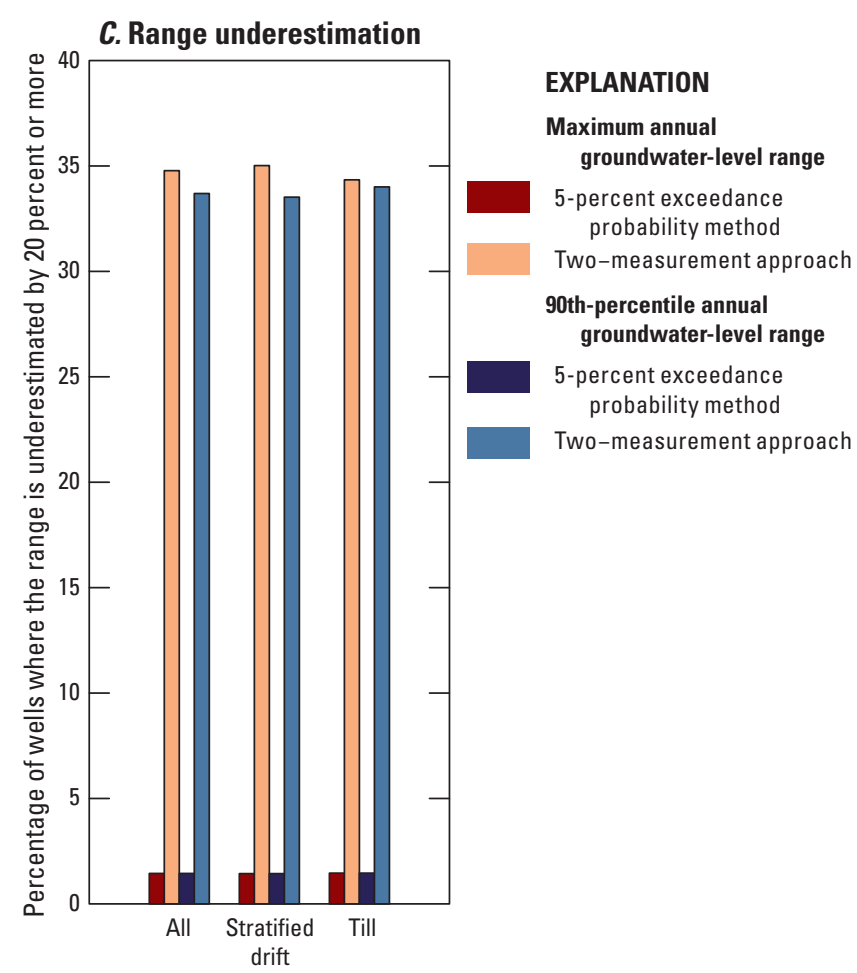

Surficial deposit type

Figure 17. Evaluation of estimations of the maximum and 90th-percentile annual groundwater-level range using either the 5-percent exceedance probability or the two-measurement approach, as indicated by the $A$, mean error, $B$, mean absolute error, and $C$, percentage of sites at which the range was underestimated by 20 percent or more.

elevation, and at a similar distance from the nearest stream; receiving similar amounts of precipitation and recharge; and situated close together (table 6). Correlations for pairs of wells, at least one of which was in stratified drift or glacial till, were mostly similar to the correlations with predictor variables for all well pairs. The one exception was that the correlation between water levels in two wells finished in glacial till was higher if both wells were in the same topographic setting.

\section{Predictive Equation for Index Well Selection}

To develop the prediction equation, a multiple linearregression equation was developed to explore the relations between predictor variables and the correlations with the goal of predicting the most highly correlated index well for each test site. Potential predictor variables included geographic distance between the pair of wells and similarity of the following: surficial deposit, topographic setting, elevation of land surface, aspect, slope, estimated annual recharge, annual precipitation, monthly groundwater levels, proximity to a water body, elevation above a stream or river, and two topographic indices [the topographic index (Beven and Kirkby, 1979) and the topographic position index (Weiss, 2001)]. Numeric variables were first calculated as differences and then multiplied by -1 so that larger values indicated greater similarity. All numeric variables were standardized by subtracting the mean and dividing by the standard deviation (Larose and Larose, 2015, p. 31), and highly cross-correlated variables (rho $>0.75)$ were dropped using the caret package in R (Kuhn, 2018; R Core Team, 2018) prior to regression analysis. The regression analysis was done for the entire well dataset and for the till and stratifieddrift subsets. For each group, the best predictor variables were identified through a model-selection process based on use of the leaps package in R (Lumley, 2009; R Core Team, 2018) and with the Bayesian information criterion (BIC) as the test statistic. Variables with negative coefficients, which indicated that wells with less similar traits responded more similarly than wells with more similar traits, were assumed to be statistical artifacts and were dropped. Also, variables with coefficients that did not differ from 0 at the 95 -percent confidence level were dropped. The regression predicts the correlation between water levels at the test site and a potential index well. The most highly correlated potential index well can then be selected as the index well. Inputs and outputs to the regression equation are further described in appendix 2 and Barclay and Mullaney (2020). The predictive regression equation served as one approach to selecting the best index well.

The subset of variables that best predicted the correlation between two wells for all well pairs were (1) the proximity of the wells to one another; similarities in (2) annual recharge, (3) precipitation, (4) distance to the nearest stream, (5) 
Table 6. Correlations between well-pair water-level correlations and possible predictor variables for wells in Massachusetts and surrounding States.

[Correlations for stratified drift and till wells include all pairs of wells in which at least one of the wells is in the specified surficial deposit]

\begin{tabular}{|c|c|c|c|}
\hline Variable & All wells & Stratified drift wells & Till wells \\
\hline Same surficial deposit & 0.00 & -0.08 & 0.25 \\
\hline Same topographic setting & 0.10 & 0.00 & 0.29 \\
\hline Proximity & 0.22 & 0.21 & 0.24 \\
\hline Similar aspect & -0.02 & -0.03 & -0.03 \\
\hline Similar topographic index & -0.07 & -0.09 & -0.06 \\
\hline Similar recharge & 0.10 & 0.08 & 0.11 \\
\hline Similar precipitation & 0.17 & 0.16 & 0.18 \\
\hline Similar topographic position index at 500 meters & -0.02 & -0.02 & 0.00 \\
\hline Similar topographic position index at 2,000 meters & 0.00 & 0.02 & 0.00 \\
\hline
\end{tabular}

elevation; and (6) whether the wells were in the same surficial deposit and topographic setting (table 7). This list is similar to the list for the subset of well pairs in which at least one of the wells was in till and stratified drift, except that being in the same surficial deposit and topographic group was not included for wells in stratified-drift deposits, and similar elevations were not included for wells in till deposits.

\section{Comparison of Index Well Selection Approaches}

For wells in till, the median groundwater-level correlation between a test site and an index well was highest if the nearest well in the same surficial deposit (glacial till) was selected as the index well (rho $=0.82$; fig. 18A). Median water-level correlations were lowest if the index well was selected at random (regardless of geologic or topographic setting; rho $=0.67)$. Among the other approaches, the median correlations were similar (rho $=0.75$ to 0.81 ). Using the regression equation to identify the best index well did not improve the correlation between measurements at the test site and the index well as compared to simply selecting the nearest well in till deposits. The regression equation was also more difficult to implement than to select the nearest well.

For wells in stratified drift, the median groundwaterlevel correlation with an index well was also highest when the nearest well in the same surficial deposit (stratified drift) was selected $($ rho $=0.72$; fig. $19 B)$. Among the other approaches, the median correlations were similar (rho $=0.62$ to 0.69$)$. As

Table 7. Regression coefficients for an equation to predict the correlation between an index well and a test well for wells in Massachusetts and surrounding States.

[Coefficients apply to data that have been standardized to a mean of 0 and a standard deviation of 1 . NS, not statistically significant at $p \leq 0.05$; Adj $R^{2}$, adjusted coefficient of determination]

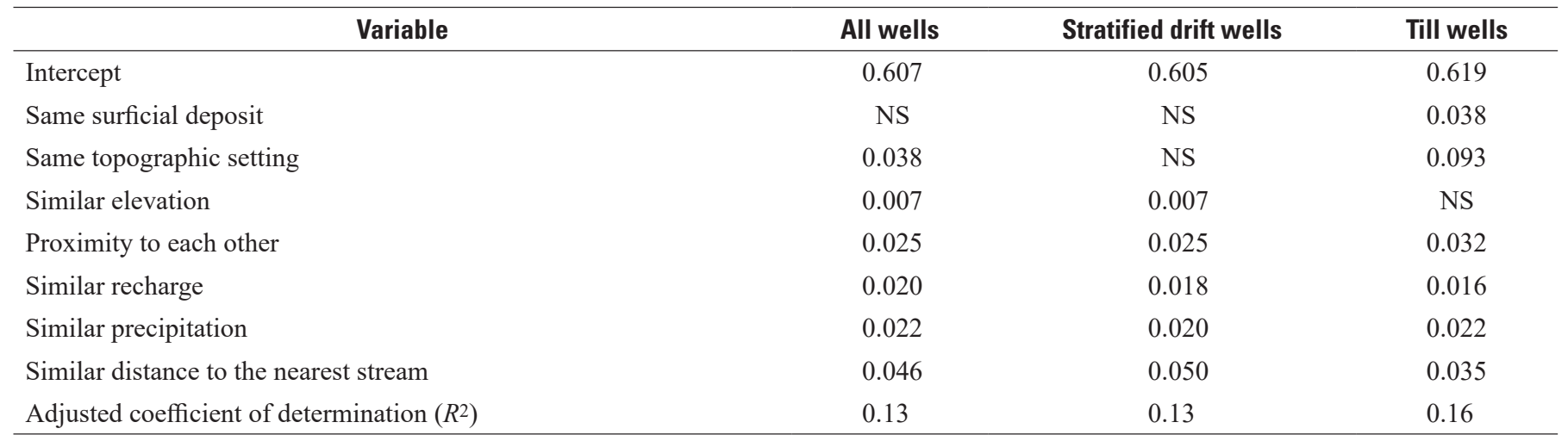


with wells in glacial till, using the regression equation to select the index well did not improve the correlation between water levels at the test site and the selected index well as compared to the other more easily implemented approaches.

\section{Assessing High Groundwater-Level Estimates}

Three metrics were used to evaluate the high groundwater-level estimates from the Frimpter (1981) method. First, the accuracy of the estimated high groundwater level was assessed by comparing the predicted and measured high groundwater levels for each test site and each testmeasurement date using the mean error and the mean absolute error. These metrics were calculated for the entire datasets and for subsets based on surficial deposit, topographic setting, and hydrologic conditions using the hydroGOF package in $\mathrm{R}$ (Zambrano-Bigiarini, 2017; R Core Team, 2018). Second, the frequency with which the observed high groundwater level exceeded the estimated high groundwater level was calculated for each test site and test measurement. Third, each site was classified as suitable or unsuitable for an unmounded septic system based on a threshold high groundwater level of $6 \mathrm{ft}$ below land surface and the estimated high groundwater level. This threshold accounts for the required 4-ft vertical separation between the septic drainage field and the high groundwater level and for $2 \mathrm{ft}$ of the thickness of the drainage bed. After this classification was done, the ability of the method to correctly classify the site was assessed.

The estimated high groundwater levels were assessed using two approaches to estimate the annual groundwaterlevel range (5-percent exceedance probability from either the maximum annual groundwater-range distribution or the 90th percentile of the annual groundwater-range distribution) and five approaches to select an index well. The two-measurement approach to estimate the annual groundwater-level range was not considered further because of the high probability of underestimating the observed annual groundwater-level range by more than 20 percent. The regression equation approach to selecting an index well was not considered further because this approach is much more difficult to implement than other approaches and, compared with other approaches, did not improve the correlation between the groundwater levels measured in the test well and in the selected index well.

Finally, one additional metric was used to quantify the effect of groundwater levels at the time of the test measurement on the accuracy of the estimated high groundwater level. Errors in the estimated high groundwater level (compared with the observed high groundwater level) were compared across five water-level groups (low, slightly low, midrange, slightly high, and high). The water-level groups refer to water levels at the time of the test measurement compared with water levels during the historical period of record for the test site. For this analysis, the nearest well in the same surficial deposit was selected as the index well, and both approaches to estimating the annual groundwater-level range were used.

\section{Accuracy of Estimated High Groundwater Level}

The accuracy of the estimated high groundwater level varied with the approaches used to estimate the annual groundwater-level range and select an index well. Errors for test-site and test-measurement date pairs ranged from -27.0 to $14.8 \mathrm{ft}$, with a median error of $-1.9 \mathrm{ft}$ (fig. 19). The mean error for the estimated high groundwater level ranged from -3.23 to $-1.40 \mathrm{ft}$ for all approaches and hydrologic conditions used to estimate the annual groundwater-level range and to select an index well (table 8). Negative values for the mean error indicate that, in general, the estimated high groundwater level is higher (on average, 1.40 to $3.23 \mathrm{ft}$ higher) than the observed high groundwater level. The mean absolute error for the estimated high groundwater level ranged from 2.79 to $3.97 \mathrm{ft}$, indicating that, in general, the estimated high groundwater level was off (either high or low) by 2.79 to $3.97 \mathrm{ft}$.

The approach to estimating the annual groundwater-level range had a greater effect on the accuracy of the estimated high groundwater level than the choice of an index well. The magnitude of the mean errors was smaller if the range was estimated using the 5-percent exceedance probability of the 90th percentile of annual groundwater-level ranges instead of the distribution of the maximum annual groundwater-level ranges $(-1.73$ to $-1.40 \mathrm{ft}$ compared with -3.23 to $-2.99 \mathrm{ft}$; fig. 19; table 8). Similarly, the magnitude of the mean absolute error was smaller if estimated by the 90th-percentile distribution instead of the maximum distribution (2.79 to $3.09 \mathrm{ft}$ compared with 3.78 to $3.97 \mathrm{ft}$ ). These reductions in the mean error and mean absolute error were likely caused by the removal of extreme values in annual groundwater-level ranges from the statistical distributions. The approach to choosing an index well (for example, randomly from any surficial material, or the nearest index well in the same surficial material) had less effect on the mean error and the mean absolute error, resulting in maximum differences of $0.24 \mathrm{ft}$ in the mean error $(-2.99$ to $-3.23 \mathrm{ft})$ and $0.19 \mathrm{ft}$ in the mean absolute error $(3.78$ to $3.97 \mathrm{ft}$ ) when the range was estimated from the maximumrange distribution, and $0.33 \mathrm{ft}$ in the mean error $(-1.4$ to $-1.73 \mathrm{ft}$ ) and $0.30 \mathrm{ft}$ in the mean absolute error ( 2.79 to $3.09 \mathrm{ft}$ ) when the range was estimated from the 90th-percentile distribution of annual groundwater-level ranges (table 8).

When the accuracy of the estimated high groundwater level was assessed for test sites in stratified drift and glacial till separately, the choice of index well was more important (fig. 19; table 8, middle and right columns). This was particularly true for test sites in glacial till where selecting an index well at random, regardless of surficial deposit, or by the most similar depth to water at the time of the test measurement resulted in larger magnitude mean error values than other approaches to selecting an index well, regardless of the approach to estimating the annual groundwater-level range. Mean error values were slightly lower for wells in glacial till than in stratified drift for all of the approaches used to estimate the annual groundwater-level range and select an index well, except for selection of an index well at random from any 

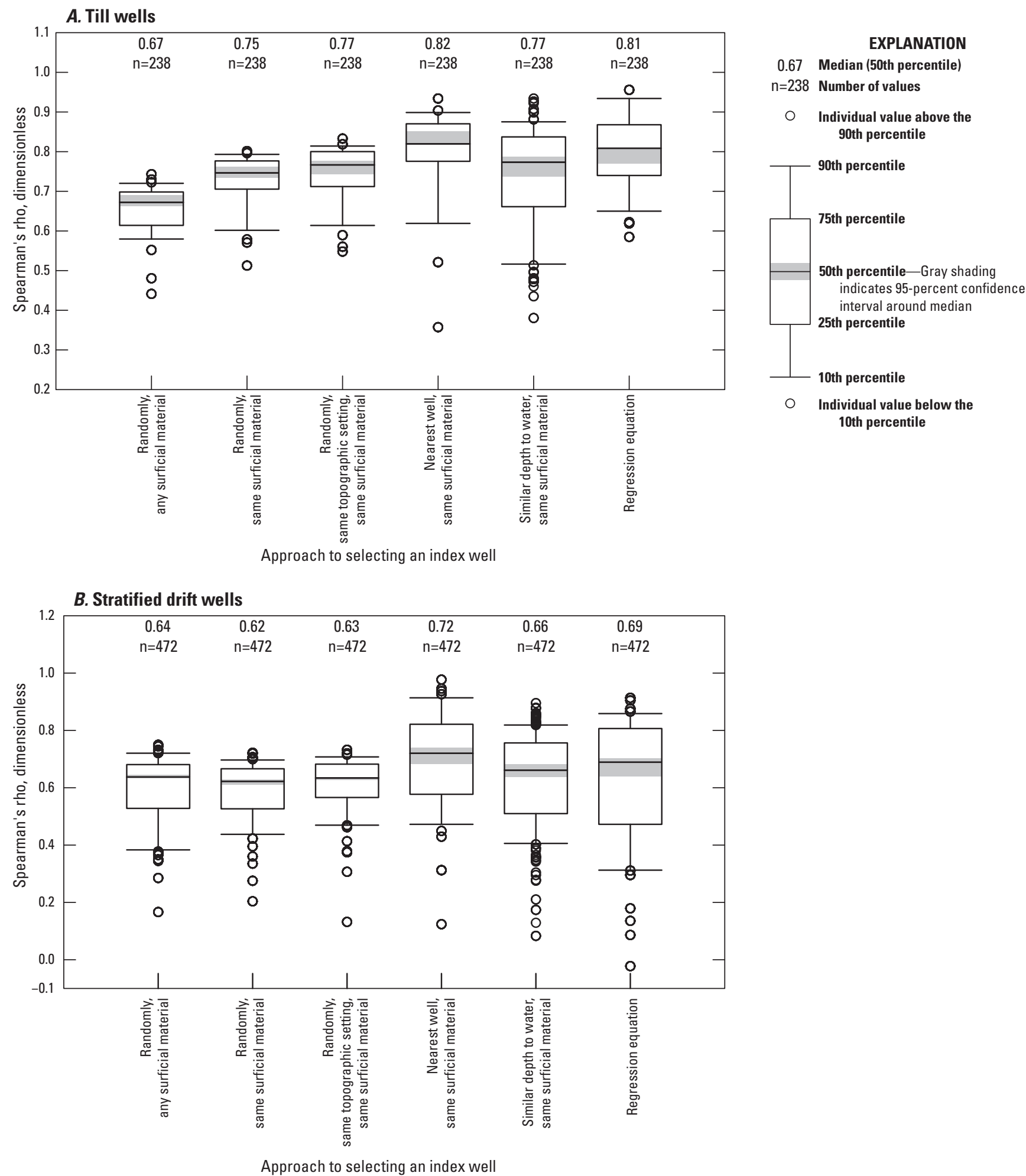

Figure 18. Comparison of Spearman's rho for index wells chosen by six different approaches for test wells in $A$, till and $B$, stratified-drift deposits in Massachusetts and surrounding States.

surficial deposit and for selection of an index well using the most similar depth to water at the time of the test measurement. Mean absolute error values were generally similar for test sites in glacial till and stratified drift unless the index well was selected at random from any surficial deposit. Selecting an index well at random from any surficial deposit likely results 
Table 8. Errors in estimated high groundwater levels for wells in Massachusetts and surrounding States.

[ft, foot]

\begin{tabular}{|c|c|c|c|c|c|c|}
\hline \multirow[b]{2}{*}{ Approach to selecting an index well } & \multicolumn{2}{|c|}{ All wells $(n=119)$} & \multicolumn{2}{|c|}{ Stratified drift wells $(n=79)$} & \multicolumn{2}{|c|}{ Till wells $(n=40)$} \\
\hline & $\begin{array}{l}\text { Mean error, } \\
\text { in } \mathrm{ft}\end{array}$ & $\begin{array}{c}\text { Mean } \\
\text { absolute } \\
\text { error, in ft }\end{array}$ & $\begin{array}{c}\text { Mean error, } \\
\text { in } \mathrm{ft}\end{array}$ & $\begin{array}{l}\text { Mean absolute } \\
\text { error, in } \mathrm{ft}\end{array}$ & $\begin{array}{l}\text { Mean error, } \\
\text { in } \mathrm{ft}\end{array}$ & $\begin{array}{l}\text { Mean } \\
\text { absolute } \\
\text { error, in ft }\end{array}$ \\
\hline \multicolumn{7}{|c|}{ Range estimated from 5-percent exceedance level of maximum ranges } \\
\hline Randomly, any surficial deposit & -2.99 & 3.92 & -2.53 & 3.48 & -3.82 & 4.7 \\
\hline Nearest well, same surficial deposit & -3.06 & 3.85 & -3.62 & 3.91 & -2.07 & 3.72 \\
\hline Similar depth to water, same surficial deposit & -3.23 & 3.78 & -2.86 & 3.39 & -3.90 & 4.48 \\
\hline \multicolumn{7}{|c|}{ Range estimated from 5-percent exceedance level of 90th-percentile ranges } \\
\hline Nearest well, same surficial deposit & -1.59 & 2.89 & -2.06 & 2.85 & -0.75 & 2.97 \\
\hline Similar depth to water, same surficial deposit & -1.73 & 2.79 & -1.55 & 2.61 & -2.04 & 3.12 \\
\hline
\end{tabular}

in higher errors for wells in glacial till; because the well network includes fewer wells in glacial till, it is likely that the randomly selected index well will be in stratified drift and may not respond like a well in glacial till.

Errors in estimated high groundwater levels varied slightly by the water levels at the time of the measurement. When the range was estimated using the 5-percent exceedance probability of the maximum annual groundwater-level range, the median error between the observed and estimated high groundwater levels ranged from -1.8 to $-3.3 \mathrm{ft}$ across all hydrologic conditions from the highest 20 percent of water levels to the lowest 20 percent of groundwater levels (fig. 20). Within the 95-percent confidence interval, the median error did not differ between the high and slightly high groundwater levels or between the slightly low and low groundwater levels, but the magnitudes of the median errors for the drier conditions (slightly low and low groundwater levels) were greater than for the wetter conditions (high, slightly high, and midrange groundwater levels). When the annual groundwater-level range was estimated from the distribution of the 90th percentile of annual groundwater-level ranges, the median error ranged from -0.6 to $-2.0 \mathrm{ft}$. Within the 95-percent confidence interval, the magnitude of the median error with midrange water levels was greater than for slightly high water levels and less than for slightly low and low water levels, and the median error for slightly low and low water levels was greater than for wetter conditions (high, slightly high, and midrange). Because the median error differed in some instances by groundwater level (with drier conditions generally having greater errors than wetter conditions), the accuracy of the estimated high groundwater levels might be slightly better if the test measurement were made during higher water levels. The magnitudes of the differences in median error between water-level groups, however, was much less than the interquartile range of error magnitudes within each group. This suggests that, although the differences in error are statistically significant in some cases, those differences are a relatively minor component of the overall error in the high groundwater-level estimates.

\section{Frequency of Exceeding the Estimated High Groundwater Level}

The approach to selecting an index well had a greater effect on the percentage of wells where groundwater levels never exceeded the estimated high groundwater level than did the approach to estimating the annual groundwater-level range. For all surficial deposits and both approaches to estimating the annual groundwater-level range, using the nearest well in the same surficial deposit as the test well resulted in the greatest number of wells where the observed groundwater level did not exceed the estimated high groundwater level (fig. 21). Estimating the annual groundwater-level range based on the 5-percent exceedance probability of the maximum annual groundwater-range distribution resulted in a higher percentage of sites where the observed groundwater levels did not exceed the estimated levels than estimating the range from the distribution of the 90th-percentile of the high groundwater levels. This result is expected due to the larger estimated ranges from the maximum annual groundwater-range 
A. Range estimated using 5-percent exceedance of maximum annual ranges

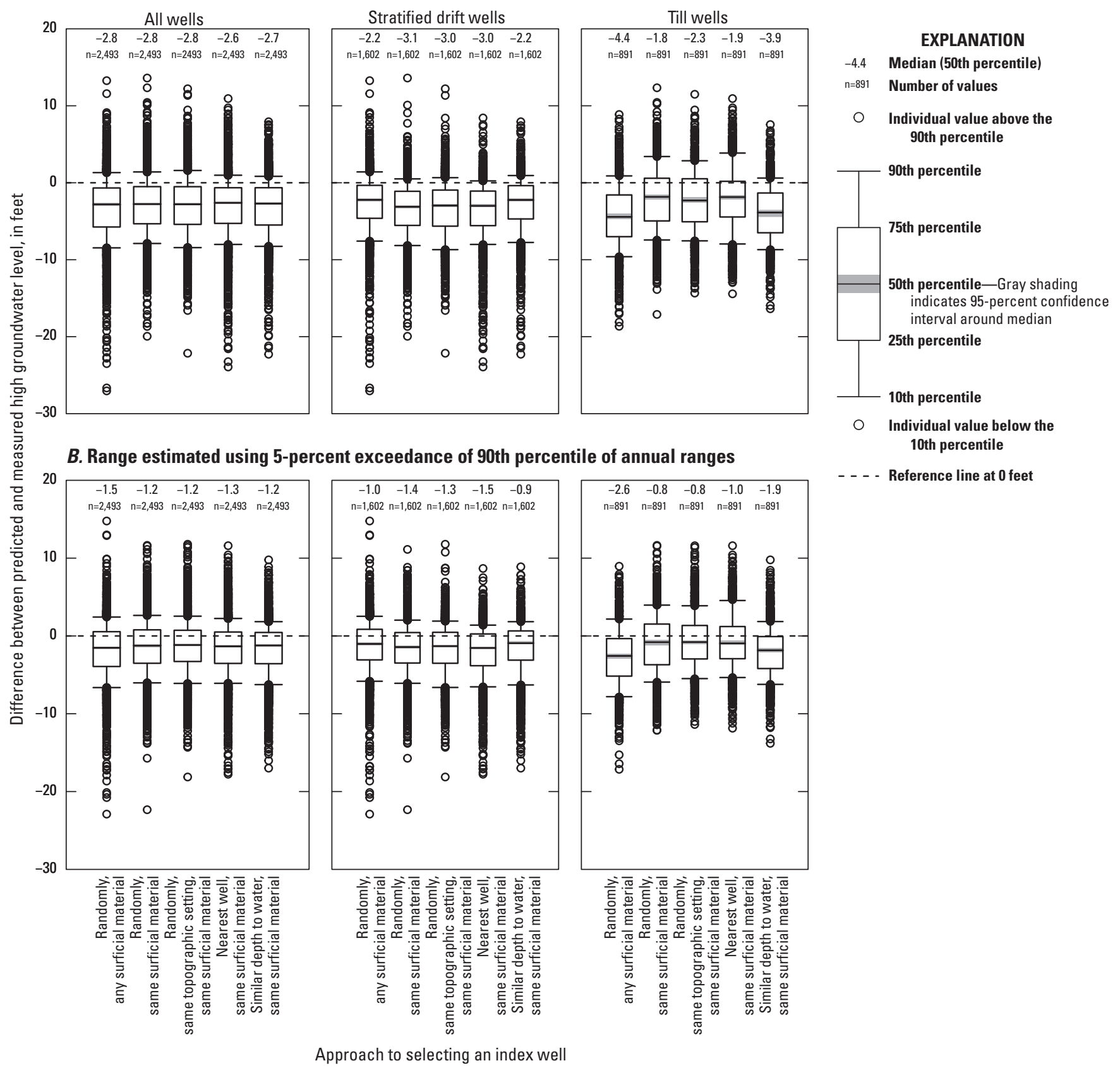

Figure 19. Differences between predicted and measured high groundwater levels for wells in Massachusetts and surrounding States. Annual groundwater-level ranges were estimated from the 5-percent exceedance probabilities of the $A$, maximum ranges or $B, 90$ th-percentile ranges. Negative values indicate that the estimated high groundwater level is higher (shallower) than the observed high groundwater level. The mean error for each group is the mean of the differences for that group (resulting from the approach for estimating the range and the approaches for selecting an index well), and the mean absolute error for each group is the mean of the absolute value of the differences for that group.

distribution. The percentage of wells in glacial till where the observed groundwater levels never exceeded the estimated high groundwater levels was lower than the percentage of wells in stratified drift where the observed groundwater levels never exceeded the estimated high groundwater level; these results applied to all approaches to selecting an index well and estimating the annual groundwater-level range. 


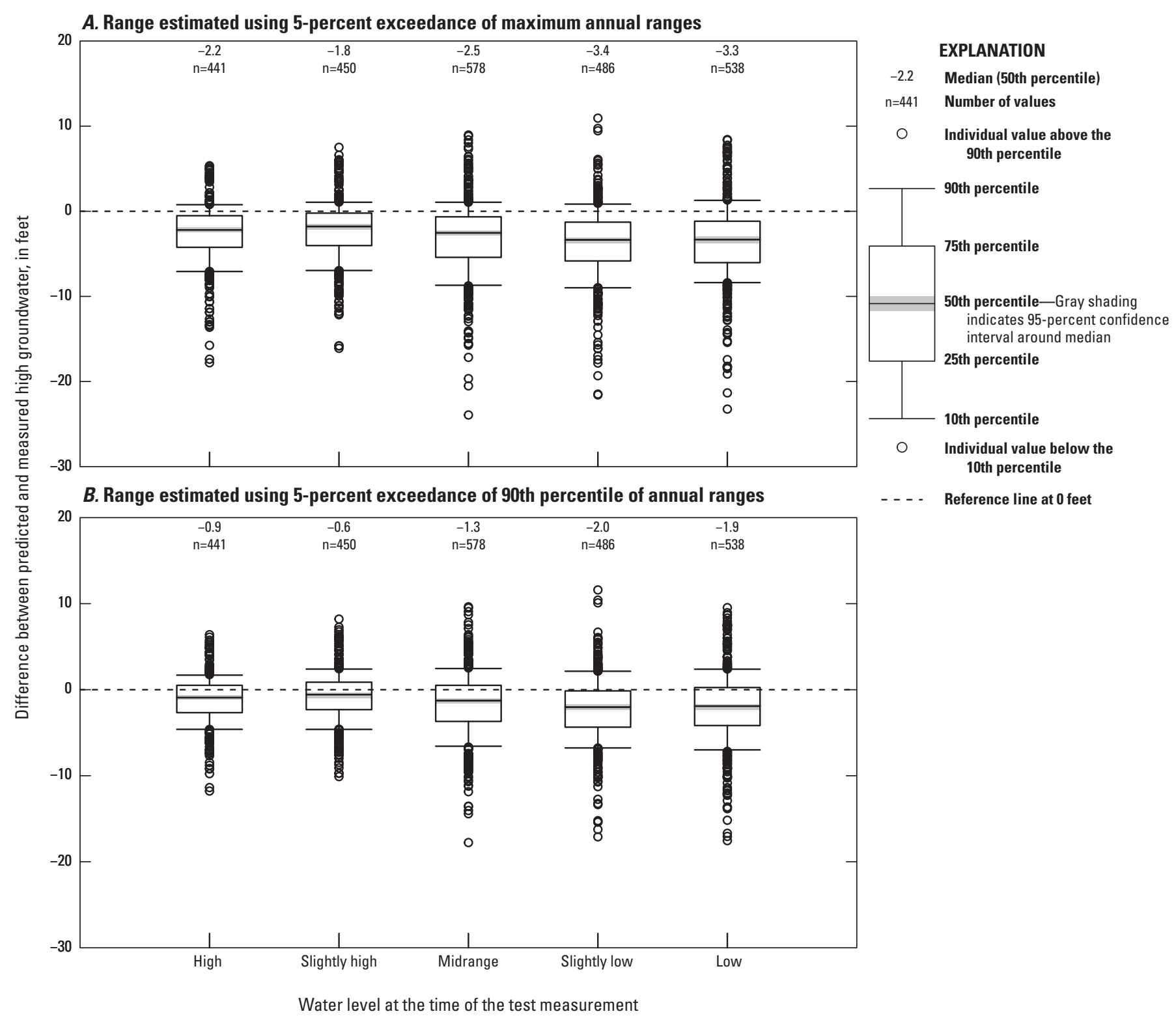

Figure 20. Differences between predicted and measured high groundwater levels for wells in Massachusetts and surrounding States at the time of the test measurement. Annual groundwater-level ranges were estimated from the 5-percent exceedance probabilities of the $A$, maximum ranges or $B$, 90th-percentile ranges. Water-level categories from high to low each represent 20 percent of the water levels in the period of record for a given site.

The observed groundwater levels in most wells exceeded the estimated high groundwater level infrequently. For the full dataset, the median frequency at which the observed groundwater level exceeded the estimated level ranged from 0.5 to 1.9 percent of months, or every 4 to 17 years, for both approaches to estimating the annual groundwater-level range and all approaches to selecting an index well (fig. 22). The median frequency of the observed groundwater level exceeding the estimated high groundwater level did not vary substantially across approaches to selecting an index well.
At some sites, however, the estimated high groundwater level was exceeded relatively frequently (in more than 5 percent of months; figs. 21 and 22). The percentage of sites that exceeded the estimated high groundwater level in more than 5 percent of months ranged from 5 to 26 percent across both approaches to estimating the annual groundwater-level range and all approaches to selecting an index well. Higher frequency exceedances were most common when the range was estimated based on the 90th percentile of annual groundwaterlevel ranges for wells in glacial till. 


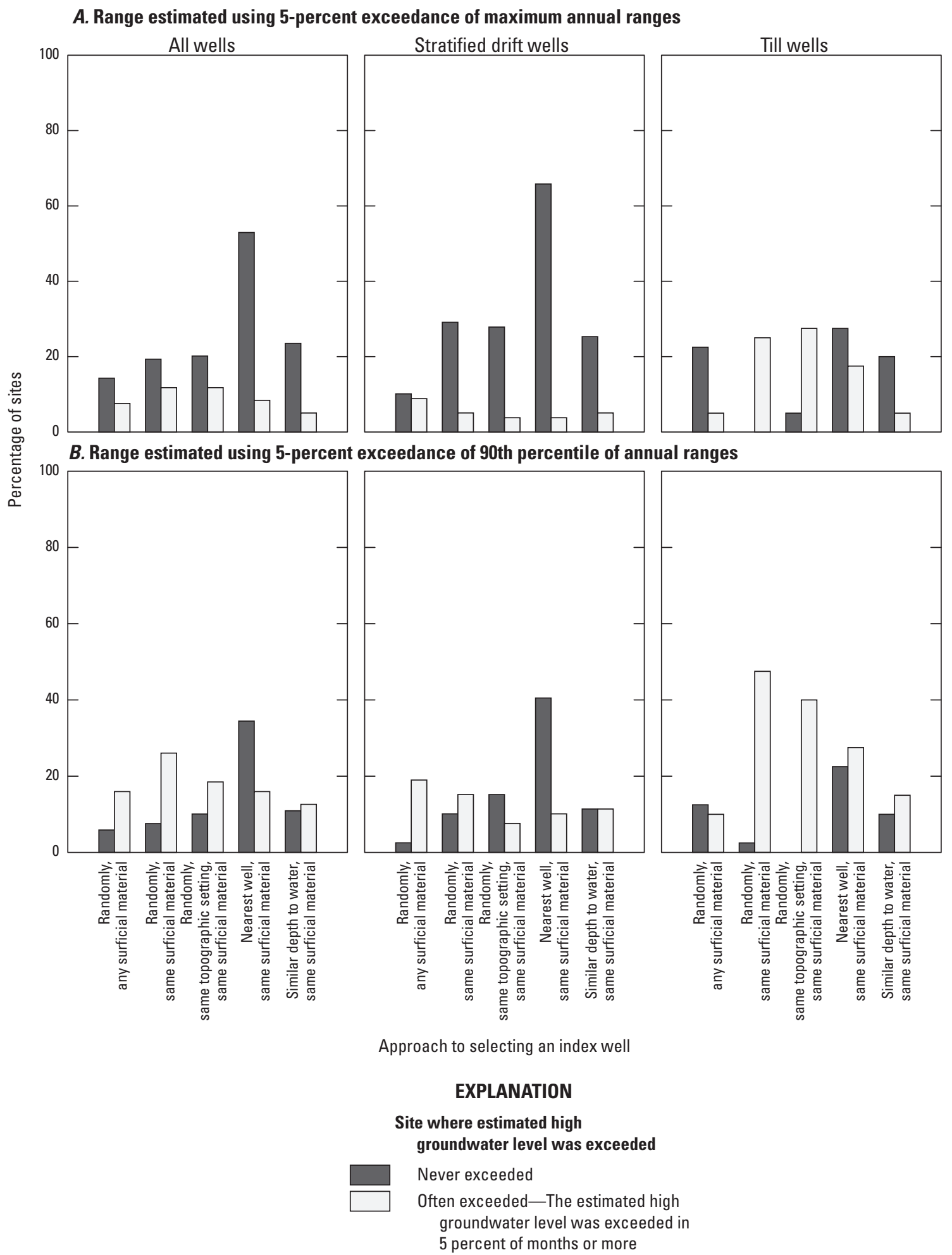

Figure 21. Percentage of sites where the observed groundwater level never or often exceeded the estimated high groundwater level in Massachusetts and surrounding States for five approaches to selecting an index well and for two approaches to estimating the annual groundwater-level range. Ranges were estimated from the 5-percent exceedance probabilities of the $A$, maximum ranges or $B, 90$ th-percentile ranges. 
A. Range estimated using 5-percent exceedance of maximum annual ranges

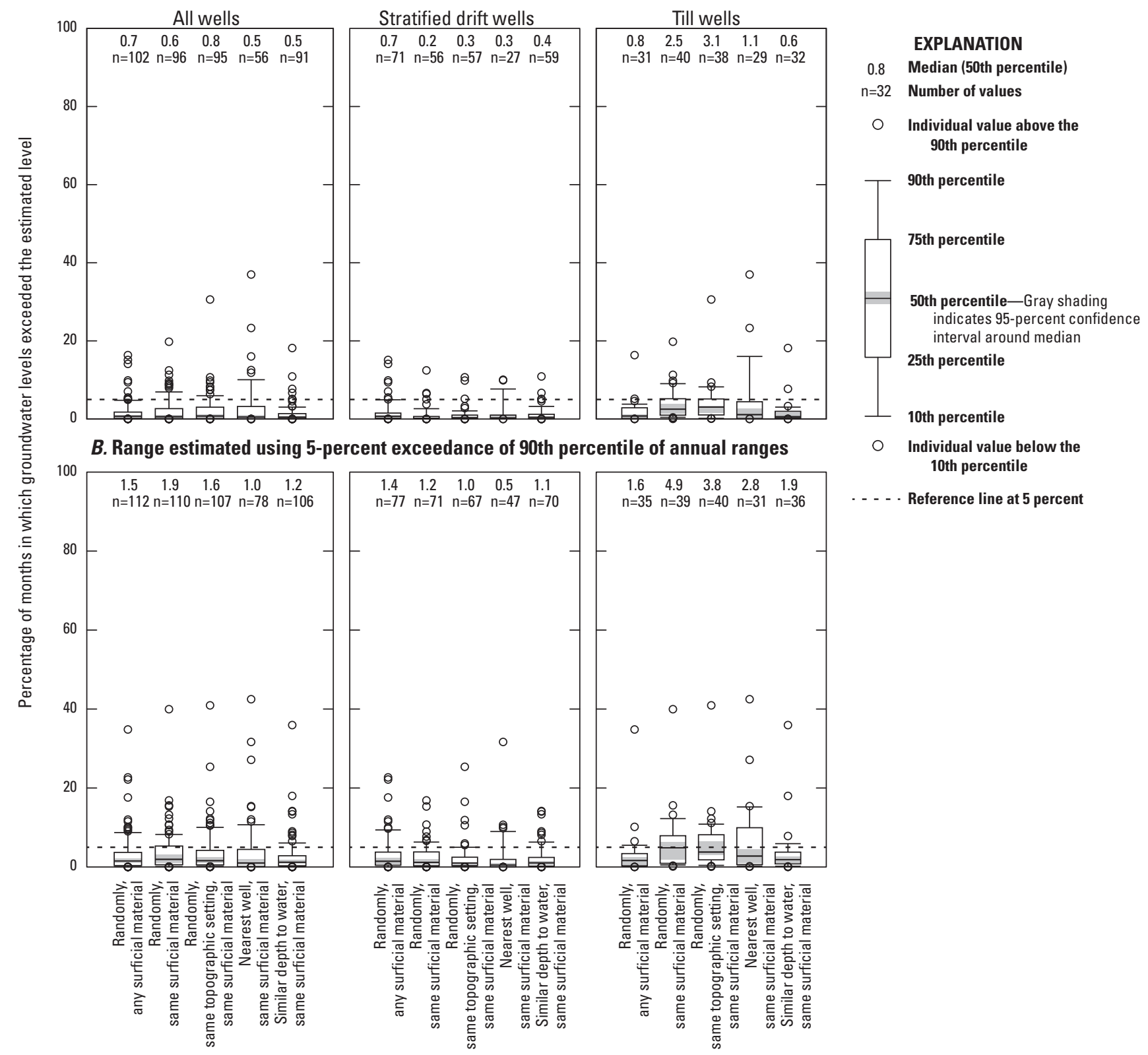

Approach to selecting an index well

Figure 22. Percentage of months in which groundwater levels exceeded the estimated high groundwater level for wells in Massachusetts and surrounding States where the estimated high groundwater level was exceeded one or more times. Annual groundwater-level ranges were estimated from the 5-percent exceedance probabilities of the $A$, maximum ranges or $B$, 90th-percentile ranges.

\section{Accuracy of Septic-System-Suitability Classification}

Most sites were correctly classified as suitable or unsuitable for an unmounded septic system regardless of the approach used for estimating the annual groundwaterlevel range or selecting an index well. Correct classification rates ranged from 83 to 86 percent for all wells under both approaches to estimating the annual groundwater-level range and all five approaches to selecting an index well (fig. 23). When the annual groundwater-level range was estimated using the distribution of the maximum groundwater-level ranges, the number of sites incorrectly classified as suitable for an unmounded septic system was lower (therefore fewer failed septic systems) than when the range was estimated from the distribution of the 90th percentile of the annual 
groundwater-level ranges ( 2.7 to 6.0 percent versus 6.6 to 10.1 percent for all wells across all approaches to selecting an index well), whereas the number of sites incorrectly classified as unsuitable for an unmounded system was higher (therefore more unnecessarily mounded systems; 9.0 to 12.1 percent for all wells versus 6.5 to 8.4 percent across all approaches to selecting an index well). Rates of correct classifications were slightly higher for sites in glacial till than for sites in stratified drift.

\section{Implementation of the Method}

The accuracy of estimated high groundwater levels and suitability for unmounded septic systems varied among approaches to estimating the annual groundwater-level range and selecting an index well. In general, the estimated high groundwater levels were higher than the observed groundwater levels, but most estimated high groundwater levels were within $4 \mathrm{ft}$ of the actual high groundwater levels. Regardless of the approach to estimating the annual groundwater-level range and selecting an index well, most sites were correctly classified as suitable or unsuitable for an unmounded septic system.

The approach to estimating the annual groundwaterlevel range introduces a tradeoff between the accuracy of the estimated levels and how frequently the estimated high groundwater level is exceeded (potentially leading to a failed septic system). Estimating the annual groundwater-level range from a distribution of the maximum annual groundwaterlevel ranges resulted in larger errors in the estimated high groundwater level, but the estimated levels were exceeded in fewer wells and less frequently than when the range was estimated from a distribution of the 90th percentile of annual groundwater-level ranges. The choice of approach to estimating the annual groundwater-level range had a minor (about 1 percent) effect on the percentage of sites correctly classified regarding unmounded septic-system suitability, but it did affect the type of error for incorrectly classified sites. When the range was estimated using the distribution of the maximum annual groundwater-level ranges, more than half of the classification errors were due to incorrectly classifying sites as unsuitable for unmounded septic systems (leading to unnecessary installation of mounded systems, which are costlier than unmounded systems). In contrast, when the range was estimated using the 90th percentile of the annual groundwaterlevel ranges, more than half of the errors were due to incorrectly classifying sites as suitable (leading to occasional septic system failure).

Unlike the approach to estimating the annual groundwater-level range, the approach to selecting an index well did not involve broad tradeoffs because it did not substantially alter the accuracy of the estimated high groundwater levels. In contrast, the approach to selecting an index well did change how frequently the estimated high groundwater level was exceeded. Across all wells and both approaches to estimating the annual groundwater-level range, using the nearest index well in the same surficial deposit resulted in fewer sites where the estimated groundwater level was exceeded than selecting an index well using other approaches. Like the approach to estimating the annual groundwater-level range, the approach to selecting an index well had little effect on the percentage of wells that were correctly classified according to their suitability for an unmounded septic system. Also similar to the approach for estimating the range, the approach for selecting the index well affected the type of incorrect classifications, particularly when the annual groundwater-level range was estimated using the distribution of the 90th percentile of annual groundwater-level ranges. For example, if the index well was selected at random and the range estimate from the 90th percentile of annual water-level ranges was used, the method resulted in slightly more incorrectly suitable classifications than incorrectly unsuitable classifications. In contrast, if the selected index well was finished in the same surficial deposit with a depth closest to the depth of water at the time of the test measurement, the method resulted in slightly more incorrectly unsuitable classifications than suitable classifications. The approach selected for estimating the annual groundwater-level range and selecting an index well will likely depend upon the importance of an accurate estimate of the high groundwater level as compared to the importance of an estimated high groundwater level that is less likely to be exceeded. 


\section{A. Range estimated using 5-percent exceedance of maximum annual ranges}

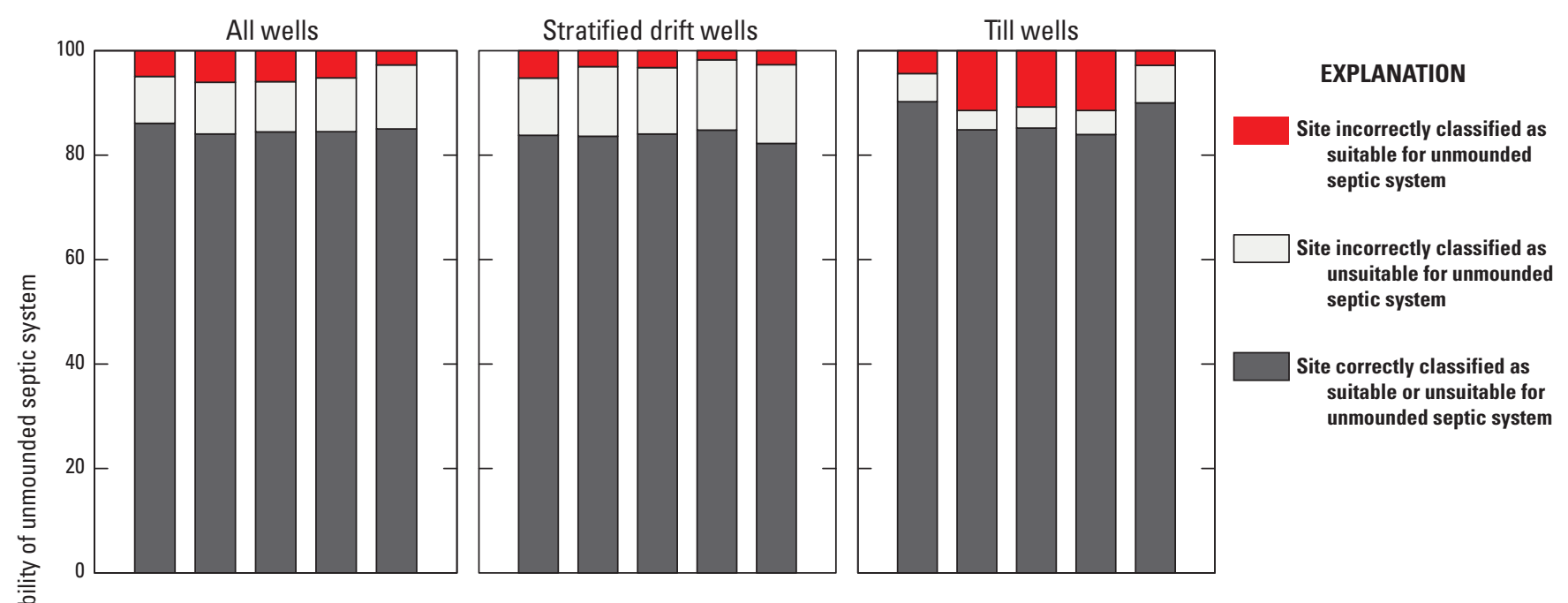

B. Range estimated using 5-percent exceedance of 90th percentile of annual ranges

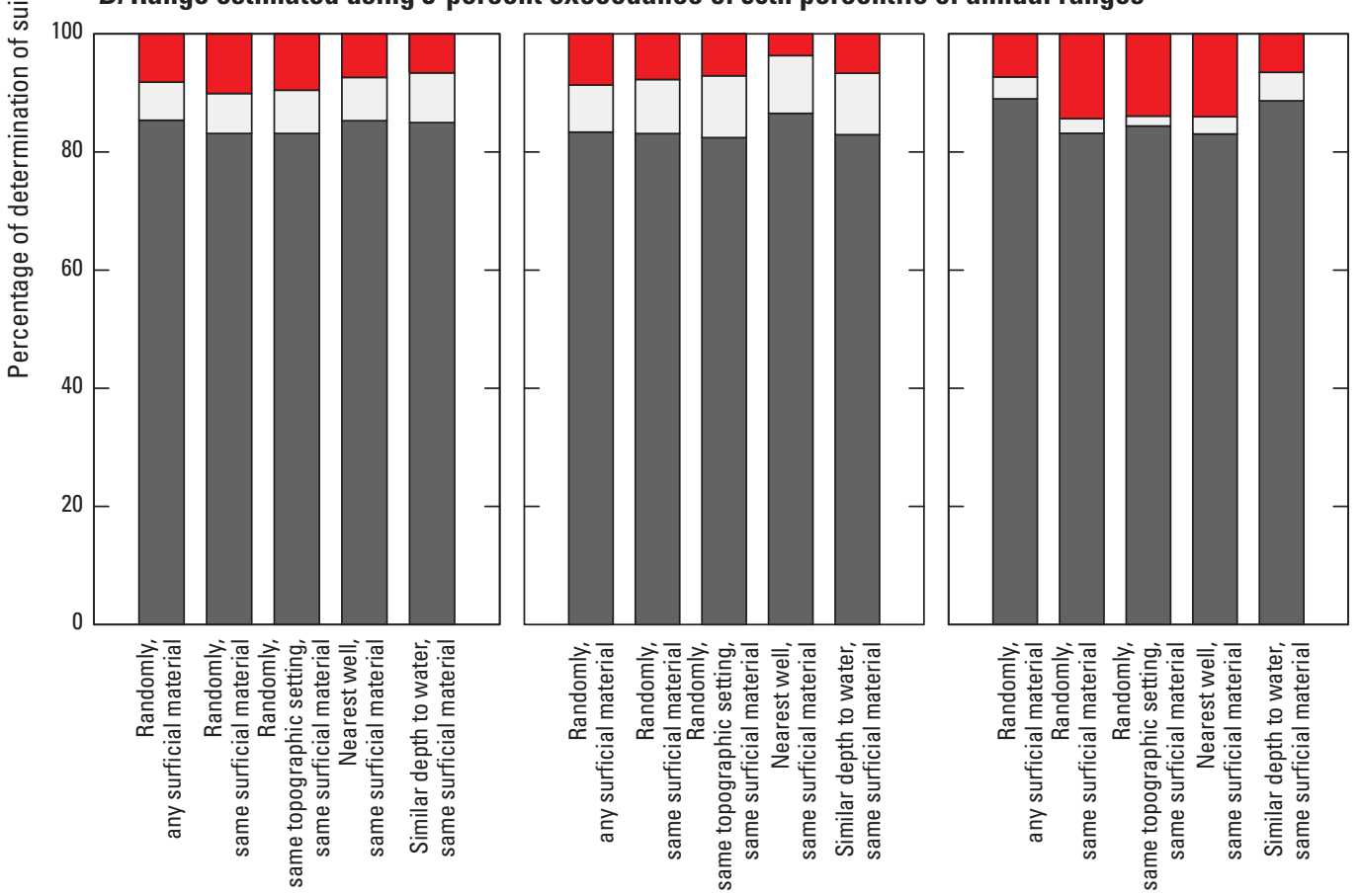

Approach to selecting an index well

Figure 23. Accuracy of determination of suitability for an unmounded septic system for wells in Massachusetts and surrounding States. Annual groundwater-level ranges were estimated from the 5-percent exceedance probabilities of the $A$, maximum ranges or $B$, 90th-percentile ranges.

\section{Summary}

Determining the suitability of a site for a septic system requires identification of the high groundwater level; absence of redoximorphic features, such as color changes indicating the elevation of the water table, from the soil profile can hinder this determination. In 1981, an alternative method for estimating the high groundwater level in Massachusetts was developed. The alternative method uses one test groundwater-level measurement at the site of interest, the current and maximum groundwater level at an index well, and the maximum annual groundwater-level ranges from U.S. Geological Survey (USGS) wells across the State. Index wells typically are near the test site and in similar geologic and topographic settings. This method is referred to as the Frimpter method by State and local agencies. Since the Frimpter method was originally developed, about 40 years of 
additional groundwater-level data have been collected at most of the USGS wells and thus have prompted an update to the statistical distributions of these groundwater levels.

The USGS, in cooperation with the Massachusetts Department of Environmental Protection, updated the Frimpter method for estimating the probable high groundwater levels in Massachusetts. This study also provided an opportunity to analyze within-month variation in groundwater levels, assess the differences in high groundwater levels based on monthly measurements versus observed daily-mean groundwater levels, quantify long-term trends in groundwater levels, and evaluate the accuracy of the method using multiple approaches to estimate the annual groundwater-level range and select an index well for a test site.

For this study, records with lengths of 16 to 78 years for 153 wells in Massachusetts and nearby in surrounding States were analyzed. The highest (shallowest in depth) recorded groundwater levels varied widely from 1.2 feet (ft) above land surface (the site was flooded) to $45.8 \mathrm{ft}$ below land surface, with a median of $4.6 \mathrm{ft}$ below land surface; the maximum annual groundwater-level ranges varied from 1.4 to $17.9 \mathrm{ft}$, with a median of $5.5 \mathrm{ft}$. Among wells on the mainland, wells screened in glacial till had shallower high groundwater levels (median of $2.2 \mathrm{ft}$ ) and larger maximum annual groundwaterlevel ranges (median of $11.4 \mathrm{ft}$ ) than wells screened in stratified drift (high groundwater level median of $4.6 \mathrm{ft}$ and maximum groundwater-level range median of $5.6 \mathrm{ft}$ ).

The within-month variation, maximum annual groundwater-level range, and highest recorded groundwater levels were computed using daily mean groundwater-level values from 28 wells with continuous records. The within-month interquartile groundwater-level range varied from 0.11 to $0.96 \mathrm{ft}$, with a median of $0.28 \mathrm{ft}$. Larger variation was associated with larger annual groundwater-level ranges, shallower high groundwater levels, and larger month-to-month variations. Computations based on daily data were compared with computations based on monthly data at the same sites. Using daily data resulted in larger maximum annual groundwaterlevel ranges ( 0.02 to $2.94 \mathrm{ft}$ larger, median of $0.58 \mathrm{ft}$ larger) and shallower highest recorded groundwater levels ( 0.0 to $1.60 \mathrm{ft}$ shallower, median of $0.18 \mathrm{ft}$ shallower) than computations based on monthly measurements in the same wells. Results suggest that monthly measurements are sufficient for calculated annual groundwater-level ranges and high groundwater-level statistics for index wells, but continuous data should be used, when available, for water levels at index wells on the day of the groundwater-level measurement at the test site.

Statistical tests showed moderate to strong support that trends were present in both high and low groundwater levels at most periods that were analyzed. High groundwater levels became shallower (higher) at most sites during four of six analysis periods (1966-2015, 1986-2015, 1991-2010, and 1981-2010). Low groundwater levels also became shallower at many sites during most periods evaluated, but this trend was less widespread than it was with high groundwater levels: a greater number of sites had trends to deeper low groundwater levels than had trends to deeper high groundwater levels. There was no clear trend in annual groundwater-level ranges at most sites during the six periods analyzed. The trends toward shallower groundwater levels could suggest the need for added depth between septic drain fields and groundwater to prevent flooding in the decades to come.

Three potential strategies for estimating the maximum annual groundwater-level range at a test site and six potential strategies for identifying an appropriate index well were analyzed. The approaches for estimating the annual groundwater-level range included (1) the approach from the original method, which uses the 5-percent exceedance probability from the probability distribution of maximum annual groundwater-level ranges at index sites in similar surficial deposits and topographic settings, (2) use of the 5-percent exceedance probability from a probability distribution of the 90th percentile of annual groundwater-level ranges from the same groups of index wells, and (3) estimating the annual groundwater-level range (including either the maximum or the 90th percentile) using two test measurements made during differing hydrologic conditions. The approaches to estimating the annual groundwater-level range were assessed by comparing the estimated and known annual groundwater-level ranges for each well. The approaches for selecting an index well were (1) random and in any surficial deposit, (2) random and in the same surficial deposits, (3) random and in the same topographic setting and surficial deposits, (4) nearest geographic distance to the test site and in the same surficial deposits, (5) water level most similar to that of the test well with respect to depth below land surface at the time of the test measurement and in the same surficial deposits, and (6) a predictive equation. The approaches to selecting an index well were assessed by comparing the correlations between test wells and potential index wells that were selected by different methods. The two-measurement approach to estimating the annual groundwater-level range and the predictive-equation approach to selecting an index well did not perform better than simpler approaches and were dropped from further investigation, leaving two approaches to estimating the annual groundwater-level range and five approaches to selecting an index well.

The Frimpter method was assessed by comparing the estimated and measured high groundwater levels, quantifying the frequency with which the measured groundwater level exceeded the estimated high level, and quantifying the errors in determining site suitability for an unmounded septic system using each of the approaches to estimating the annual groundwater-level range and to selecting an index well.

The accuracy of the estimated high groundwater level varied with the approaches used to estimate the annual groundwater-level range and select an index well, but, in general, the method predicted higher levels than the observed high groundwater levels. The approach to estimating the annual groundwater-level range had a larger effect on the accuracy of the high groundwater-level measurement than did the approach to selecting an index well, with larger 
errors caused using the maximum annual range instead of the 90th-percentile annual range. The accuracy varied slightly by hydrologic condition (groundwater levels at the time of the test measurement), with higher groundwater levels (wetter conditions) resulting in smaller errors than lower groundwater levels (drier conditions).

The number of wells where the observed groundwater levels never exceeded the estimated high groundwater level was more strongly influenced by the approach to selecting an index well than by the approach to estimating the annual groundwater-level range. For all surficial deposits and both approaches to estimating the annual groundwater-level range, use of the nearest well in the same surficial deposit as the index well resulted in the greatest number of sites where the estimated high groundwater level was not exceeded. For most wells where the estimated high groundwater level was exceeded, the exceedances were infrequent. Higher frequency exceedances were more common when the range was estimated using the 90th percentile of annual groundwater-level ranges and for wells in glacial till.

Most sites were correctly classified as suitable or unsuitable for an unmounded septic system regardless of the approach used for estimating the annual groundwaterlevel range or selecting an index well. When the annual groundwater-level range was estimated using the distribution of the maximum groundwater-level ranges, the number of sites incorrectly classified as suitable for an unmounded septic system was lower (potentially fewer failed septic systems) than when the range was estimated from the distribution of the 90th percentile of the annual groundwater-level ranges, but the number of sites incorrectly classified as unsuitable for an unmounded system was higher (therefore incorrectly requiring more mounded systems) using the distribution of the maximum groundwater-level ranges. Rates of both correct and incorrectly suitable classifications were slightly higher for sites in glacial till than for sites in stratified drift. The approach selected for estimating the annual groundwater-level range and selecting an index well will likely depend upon the importance of an accurate estimate of the high groundwater level as compared to the importance of an estimated high groundwater level that is less likely to be exceeded.

\section{Selected References}

Barclay, J.R., and Mullaney, J.R., 2020, Data on well characteristics and well-pair characteristics for estimating high groundwater levels in selected areas of Massachusetts: U.S. Geological Survey data release, https://doi.org/10.5066/ P9NM2PHP.
Beven, K.J., and Kirkby, M.J., 1979, A physically based, variable contributing area model of basin hydrology/Un modèle à base physique de zone d'appel variable de l'hydrologie du bassin versant: Hydrological Sciences Bulletin, v. 24, no. 1, p. 43-69. [Also available at https://doi.org/10.1080/ 02626667909491834.]

De Lima, V., 1991, Stream-aquifer relations and yield of stratified-drift aquifers in the Nashua River basin, Massachusetts: U.S. Geological Survey Water-Resources Investigations Report 88-4147, 47 p., accessed October 17, 2019, at https://doi.org/10.3133/wri884147.

Dudley, R.W., and Hodgkins, G.A., 2013, Historical groundwater trends in northern New England and relations with streamflow and climatic variables: Journal of the American Water Resources Association, v. 49, no. 5, p. 1198-1212. [Also available at https://doi.org/10.1111/jawr.12080.]

Filliben, J.J., 1975, The probability plot correlation coefficient test for normality: Technometrics, v. 17, no. 1, p. 111-117. [Also available at https://doi.org/10.1080/ 00401706.1975.10489279.]

Frimpter, M.H., 1981, Probable high ground-water levels in Massachusetts: U.S. Geological Survey Open-File Report 80-1205, 22 p., accessed October 17, 2019, at https://doi.org/10.3133/ofr801205.

Frimpter, M.H., and Belfit, G.C., 2006, Estimation of high groundwater levels for construction and land use planning - A Cape Cod Massachusetts example [updated 1991, revised 2006]: Cape Cod Commission Technical Bulletin 92-001, [41 p.], accessed September 4, 2018, at https://www.capecodcommission.org/resources/regulatory/ HighGroundH20TechBulletin.pdf. [Document moved to https://www.capecodcommission.org/resource-library/file/? url=/dept/commission/team/Website_Resources/regulatory/ HighGroundH20TechBulletin.pdf at time of publication.]

Frimpter, M.H., and Fisher, M.N., 1983, Estimating highest ground-water levels for construction and land use planning-A Cape Cod, Massachusetts, example: U.S. Geological Survey Water-Resources Investigations Report 83-4112, 23 p., 4 pls., accessed October 17, 2019, at https://doi.org/10.3133/wri834112.

Helsel, D.R., and Hirsch, R.M., 2002, Statistical methods in water resources: U.S. Geological Survey Techniques of Water-Resources Investigations, book 4, chap. A3, 523 p., accessed October 17, 2019, at https://doi.org/10.3133/ twri04A3. 
Hirsch, R.M., Archfield, S.A., and De Cicco, L.A., 2015, A bootstrap method for estimating uncertainty of water quality trends: Environmental Modelling \& Software, v. 73, p. 148-166. [Also available at https://doi.org/10.1016/ j.envsoft.2015.07.017.]

Jackson, J.A., ed., 1997, Glossary of geology 4th ed.: Alexandria, Va., American Geosciences Institute, 769 p.

Kuhn, M., 2018, caret-Classification and regression training (version 6.0-80): The Comprehensive R Archive Network web page, accessed October 17, 2019, at https://CRAN.R-project.org/package=caret.

Larose, D.T., and Larose, C.D., 2015, Data mining and predictive analytics 2nd ed. Wiley Series on Methods and Applications in Data Mining, 824 p.

Lumley, T., 2009, leaps-Regression subset selection (ver. 2.9): The Comprehensive R Archive Network web page, accessed October 17, 2019, at http://CRAN.R-project.org/ package $=$ leaps.

Massachusetts Department of Environmental Protection, 2016, 310 CMR 15.000 - The state environmental code, title 5-Standard requirements for the siting, construction, inspection, upgrade and expansion of on-site sewage treatment and disposal systems and for the transport and disposal of septage: Massachusetts Department of Environmental Protection, 96 p., accessed September 27, 2018, at https://www.mass.gov/files/documents/2017/09/27/ $310 \mathrm{cmr} 15 . p d f$.

Millard, S.P., 2013, EnvStats—An R package for environmental statistics: Wiley StatsRef-Statistics Reference Online, accessed October 17, 2019, at https://doi.org/10.1002/ 9781118445112.stat07181.

R Core Team, 2018, R-Language and environment for statistical computing (version 3.5.1): The R Project for Statistical Computing website, accessed October 17, 2019, at http://www.R-project.org.
Socolow, R.S., Frimpter, M.H., Turtora, M., and Bell, R.W., 1994, A technique for estimating ground-water levels at sites in Rhode Island from observation-well data: U.S. Geological Survey Water-Resources Investigations Report 94-4138, 43 p., accessed October 17, 2019, at https://doi.org/10.3133/wri944138.

U.S. Environmental Protection Agency, 2001, Managing septic systems to prevent contamination of drinking water: U.S. Environmental Protection Agency Source Water Protection Practices Bulletin EPA 816-F-01-021, [5 p.], accessed November 5, 2018, at https://www.epa.gov/sites/production/ files/2015-06/documents/2006_08_28_sourcewater_pubs septic.pdf.

U.S. Environmental Protection Agency, 2002, Onsite wastewater treatment systems manual: U.S. Environmental Protection Agency EPA/625/R-00/008, [variously paged], accessed October 17, 2019, at https://www.epa.gov/sites/ production/files/2015-06/documents/2004_07_07_septics _ septic_2002_osdm_all.pdf.

U.S. Geological Survey, 2015, Statistic USGS water science R functions: U.S. Geological Survey GitHub USGS-R/ smwrStats web page, accessed November 28, 2018, at https://github.com/USGS-R/smwrStats.

Weiss, A.D., 2001, Topographic position and landforms analysis: Esri International User Conference, San Diego, Calif., July 9-13, poster, accessed November 1, 2019, at http://www.jennessent.com/downloads/TPI-poster-TNC_ 18x22.pdf.

Zambrano-Bigiarini, M., 2017, hydroGOF-Goodness-offit functions for comparison of simulated and observed hydrological time series (version 0.3-10): The R Project for Statistical Computing website, accessed October 17, 2019, at https://cran.r-project.org/web/packages/hydroGOF/ index.html. 


\section{Appendix 1. Groundwater Observation Wells in Massachusetts and Surrounding States}

\section{References Cited}

Barclay, J.R., and Mullaney, J.R., 2020, Data on well characteristics and well-pair characteristics for estimating high groundwater levels in selected areas of Massachusetts: U.S. Geological Survey data release, https://doi.org/10.5066/ P9NM2PHP.
Frimpter, M.H., 1981, Probable high ground-water levels in Massachusetts: U.S. Geological Survey Open-File Report 80-1205, 22 p., accessed October 17, 2019, at https://doi.org/10.3133/ofr801205.

U.S. Geological Survey, 2018, USGS water data for the Nation: U.S. Geological Survey data release, accessed January 18, 2018, at https://doi.org/10.5066/F7P55KJN. 
Table 1.1. U.S. Geological Survey groundwater-observation wells in Massachusetts and surrounding States.

[Wells have been grouped by setting, designated as the surficial deposit (stratified drift or till) and the topographic position. Additional information on these wells can be found in Barclay and Mullaney (2020). Map no. refers to number on figure 2. Site number refers to the U.S. Geological Survey station number (U.S. Geological Survey, 2018). Numbers in the "Notes" column indicate the well was used for the corresponding trend period from table 2 of this report. *, continuous record well; +, well used in analysis of Frimpter (1981); CC, Cape Cod, Martha's Vineyard, and Nantucket Island]

\begin{tabular}{|c|c|c|c|c|c|}
\hline $\begin{array}{c}\text { Map } \\
\text { no. }\end{array}$ & Site number & Station name & $\begin{array}{l}\text { Decimal } \\
\text { latitude }\end{array}$ & $\begin{array}{l}\text { Decimal longi- } \\
\text { tude }\end{array}$ & Notes \\
\hline \multicolumn{6}{|c|}{ Stratified drift, hill } \\
\hline 15 & 414704072580501 & CT-BU 143 & 41.78425 & -72.9673306 & \\
\hline 42 & 414825072185601 & CT-MS 45 & 41.807183 & -72.3152528 & \\
\hline 43 & 414815072183401 & CT-MS 75 & 41.804031 & -72.3083222 & \\
\hline 53 & 414237072034401 & CT-SC 20 & 41.710376 & -72.0617425 & \\
\hline 54 & 414240072033201 & CT-SC 22 SCOTLAND & 41.711017 & -72.0591667 & $*, 5$ \\
\hline 28 & 414910072372101 & CT-SW 64 & 41.819403 & -72.6221778 & \\
\hline 2 & 415925073252001 & CT-SY 15 & 41.990211 & -73.4217944 & \\
\hline 3 & 415956073241501 & CT-SY 24 SALISBURY, CT & 41.999042 & -73.4038639 & 4 \\
\hline 134 & 413956070164301 & MA-A1W 230 BARNSTABLE, MA & 41.663722 & -70.2775211 & $\mathrm{CC},+$ \\
\hline 132 & 413930070190901 & MA-A1W 306 BARNSTABLE, MA & 41.658444 & -70.3186334 & $\mathrm{CC}, *$ \\
\hline 87 & 422812071244401 & MA-ACW 158 ACTON, MA & 42.470114 & -71.4118806 & $+, *, 1,2,3,4,5,6$ \\
\hline 121 & 414129070361401 & MA-BHW 198 BOURNE, MA & 41.691495 & -70.6033639 & $\mathrm{CC},+, *, 1$ \\
\hline 31 & 421012072324501 & MA-CMW 95 CHICOPEE, MA & 42.170093 & -72.5453655 & \\
\hline 119 & 412154070404701 & MA-CNW 36 CHILMARK, MA & 41.365114 & -70.6791943 & $\mathrm{CC}$ \\
\hline 22 & 423809072435601 & MA-CSW 8 COLRAIN, MA & 42.635918 & -72.731759 & + \\
\hline 91 & 422650071214402 & MA-CTW 167 CONCORD, MA & 42.447316 & -71.3617266 &,+ 1 \\
\hline 29 & 423310072355801 & MA-DFW 44 DEERFIELD, MA & 42.552864 & -72.598978 &,+ 1 \\
\hline 103 & 414705071045301 & MA-F3W 23 FREETOWN, MA & 41.784824 & -71.080877 & $+, 1,2,4$ \\
\hline 14 & 420259072581701 & MA-GLW 6 GRANVILLE, MA & 42.049816 & -72.9709367 & $+, *, 1$ \\
\hline 49 & 422058072085501 & MA-HHW 1 HARDWICK, MA & 42.349444 & -72.1486111 &,+ 1 \\
\hline 105 & 424841071004101 & MA-HLW 23 HAVERHILL, MA & 42.811606 & -71.0116222 & $+, *, 1,2,3,4,5,6$ \\
\hline 112 & 415228070554601 & MA-LKW 14 LAKEVILLE, MA & 41.874546 & -70.9289297 & $+, *, 1,2,3,4,5,6$ \\
\hline 20 & 421240072490201 & MA-M7W 19 MONTGOMERY, MA & 42.211267 & -72.8169972 & \\
\hline 97 & 415812071111101 & MA-N4W 37 NORTON, MA & 41.9701 & -71.1858828 & $+, 1,2,4$ \\
\hline 147 & 411712070022801 & MA-NBW 198 NANTUCKET, MA & 41.286789 & -70.0405706 & $\mathrm{CC}$ \\
\hline 45 & 423441072170701 & MA-ORW 63 ORANGE, MA & 42.578143 & -72.2848063 & \\
\hline 39 & 422103072241103 & MA-PDW 24 PELHAM, MA & 42.350924 & -72.4025847 & \\
\hline 8 & 422745073112001 & MA-PTW 51 PITTSFIELD, MA & 42.462585 & -73.1884366 & $+, *, 1,2,3,4,5,6$ \\
\hline 117 & 415453070434901 & MA-PWW 22 PLYMOUTH, MA & 41.914925 & -70.7297667 & $+, *, 1$ \\
\hline 32 & 422607072324401 & MA-S6W 7 SUNDERLAND, MA & 42.435366 & -72.5450879 &,+ 1 \\
\hline 4 & 420351073193602 & MA-SJW 58 SHEFFIELD, MA & 42.064044 & -73.3265444 & $*$ \\
\hline 60 & 422520071483001 & MA-SYW 177 STERLING, MA & 42.422314 & -71.8078499 & \\
\hline 68 & 424055071435301 & MA-TRW 13 TOWNSEND, MA & 42.682033 & -71.730906 &,+ 1 \\
\hline 116 & 414518070435701 & MA-WFW 51 WAREHAM, MA & 41.755156 & -70.7320167 & + \\
\hline 65 & 422341071464901 & $\begin{array}{l}\text { MA-WSW } 26 \text { WEST BOYLSTON, } \\
\text { MA }\end{array}$ & 42.394783 & -71.7798528 & $*$ \\
\hline 50 & 421410072081301 & $\begin{array}{l}\text { MA-WUW } 2 \text { WEST BROOKFIELD, } \\
\text { MA }\end{array}$ & 42.236204 & -72.1364665 &,+ 1 \\
\hline 26 & 420646072420101 & MA-WVW 62 WESTFIELD, MA & 42.112871 & -72.6998144 & + \\
\hline
\end{tabular}


Table 1.1. U.S. Geological Survey groundwater-observation wells in Massachusetts and surrounding States.—Continued

[Wells have been grouped by setting, designated as the surficial deposit (stratified drift or till) and the topographic position. Additional information on these wells can be found in Barclay and Mullaney (2020). Map no. refers to number on figure 2. Site number refers to the U.S. Geological Survey station number (U.S. Geological Survey, 2018). Numbers in the "Notes" column indicate the well was used for the corresponding trend period from table 2 of this report. *, continuous record well; +, well used in analysis of Frimpter (1981); CC, Cape Cod, Martha's Vineyard, and Nantucket Island]

\begin{tabular}{lclccc}
\hline $\begin{array}{c}\text { Map } \\
\text { no. }\end{array}$ & Site number & \multicolumn{1}{c}{ Station name } & $\begin{array}{c}\text { Decimal } \\
\text { latitude }\end{array}$ & $\begin{array}{c}\text { Decimal longi- } \\
\text { tude }\end{array}$ & Notes \\
\hline \multicolumn{5}{c}{ Stratified drift, hill-Continued } \\
\hline 21 & 421923072451001 & $\begin{array}{c}\text { MA-WXW 20 WESTHAMPTON, } \\
\text { MA }\end{array}$ & 42.341199 & -72.8062055 \\
84 & 424800071295301 & NH-NAW 218 & 42.800088 & -71.4975669 & $2,3,4,5$ \\
67 & 414223071453701 & RI-COW 342 & 41.706488 & -71.7597915 & \\
86 & 415626071254601 & RI-CUW 265 & 41.940655 & -71.428947 & $1,2,3,4,5,6$ \\
80 & 415948071325001 & RI-NSW 21 & 41.994821 & -71.5470071 & $1,2,4$ \\
82 & 412918071321001 & RI-SNW 6 SOUTH KINGSTOWN, & 41.488434 & -71.5356159 & $*, 2,3,4,5$ \\
& RI & & \\
\hline
\end{tabular}

\begin{tabular}{|c|c|c|c|c|c|}
\hline \multicolumn{6}{|c|}{ Stratified drift, valley } \\
\hline 41 & 414833072190301 & CT-CV 51 & 41.809265 & -72.317025 & \\
\hline 34 & 415458072291901 & CT-EL 82 & 41.916264 & -72.4885417 & \\
\hline 48 & 414548072114501 & CT-MS 19 & 41.763222 & -72.1948972 & 1 \\
\hline 5 & 420125073193001 & $\mathrm{CT}-\mathrm{NOC} 7$ & 42.023383 & -73.3248389 & 1 \\
\hline 55 & 414240072032202 & CT-SC 23 & 41.71121 & -72.0556312 & \\
\hline 133 & 414154070165001 & MA-A1W 247 BARNSTABLE, MA & 41.698443 & -70.2800214 & $\mathrm{CC},+, 1,2,3,4,5,6$ \\
\hline 131 & 413958070214701 & MA-A1W 254 BARNSTABLE, MA & 41.666221 & -70.3625237 & $\mathrm{CC}$ \\
\hline 11 & 421550073025101 & MA-A3W 12 BECKET, MA & 42.264111 & -73.0468472 & \\
\hline 98 & 423641071102501 & MA-AJW 462 ANDOVER, MA & 42.611482 & -71.1731124 & \\
\hline 94 & 415447071155301 & MA-ATW 83 ATTLEBORO, MA & 41.913156 & -71.264218 &,+ 1 \\
\hline 12 & 421228072585301 & MA-BEW 9 BLANDFORD, MA & 42.207868 & -72.9809352 & \\
\hline 149 & 414518070020301 & MA-BMW 21 BREWSTER, MA & 41.75511 & -70.0336284 & $\mathrm{CC},+, 1,2,4$ \\
\hline 150 & 414100070011101 & MA-CGW 138 CHATHAM, MA & 41.683445 & -70.019183 & $\mathrm{CC},+, *, 1,2,4$ \\
\hline 16 & 422733072532601 & MA-CYW 13 CUMMINGTON, MA & 42.459461 & -72.8902806 & \\
\hline 118 & 420321070433502 & MA-D4W 79 DUXBURY, MA & 42.055936 & -70.725872 & $+, *, 1$ \\
\hline 141 & 414402070083901 & MA-DGW 123 DENNIS, MA & 41.733999 & -70.1436301 & $\mathrm{CC}$ \\
\hline 140 & 414210070090901 & MA-DGW 158 DENNIS, MA & 41.702888 & -70.1519633 & $\mathrm{CC}$ \\
\hline 122 & 412346070353403 & MA-ENW 52 EDGARTOWN, MA & 41.396226 & -70.5922496 & $\mathrm{CC}$ \\
\hline 126 & 412118070311001 & MA-ENW 60 EDGARTOWN, MA & 41.355118 & -70.5189149 & $\mathrm{CC}$ \\
\hline 125 & 412358070320001 & MA-ENW 81 EDGARTOWN, MA & 41.39956 & -70.5328046 & $\mathrm{CC}$ \\
\hline 124 & 413737070330301 & MA-FSW 167 FALMOUTH, MA & 41.627103 & -70.5501678 & $\mathrm{CC}$ \\
\hline 123 & 413631070331801 & MA-FSW 173 FALMOUTH, MA & 41.608825 & -70.5544928 & $\mathrm{CC}$ \\
\hline 106 & 424322070592401 & MA-GCW 168 GEORGETOWN, MA & 42.72287 & -70.9894992 &,+ 1 \\
\hline 33 & 421355072322001 & MA-GKW 68 GRANBY, MA & 42.232036 & -72.538421 &,+ 1 \\
\hline 114 & 420353070520301 & MA-HGW 76 HANSON, MA & 42.064824 & -70.8669862 & $+, 1,2,4$ \\
\hline 95 & 422627071154002 & MA-LTW 104 LEXINGTON, MA & 42.440928 & -71.2606123 &,+ 1 \\
\hline 127 & 413525070291901 & MA-MIW 26 MASHPEE, MA & 41.590388 & -70.488083 & $\mathrm{CC}$ \\
\hline 128 & 413525070291904 & MA-MIW 29 MASHPEE, MA & 41.590388 & -70.488083 & $\mathrm{CC}$ \\
\hline 152 & 411536069591301 & MA-NBW 107 NANTUCKET, MA & 41.260123 & -69.9864028 & $\mathrm{CC}$ \\
\hline 148 & 411555070021901 & MA-NBW 228 NANTUCKET, MA & 41.265401 & -70.0380705 & $\mathrm{CC}$ \\
\hline
\end{tabular}


Table 1.1. U.S. Geological Survey groundwater-observation wells in Massachusetts and surrounding States.—Continued

[Wells have been grouped by setting, designated as the surficial deposit (stratified drift or till) and the topographic position. Additional information on these wells can be found in Barclay and Mullaney (2020). Map no. refers to number on figure 2. Site number refers to the U.S. Geological Survey station number (U.S. Geological Survey, 2018). Numbers in the "Notes" column indicate the well was used for the corresponding trend period from table 2 of this report. *, continuous record well; +, well used in analysis of Frimpter (1981); CC, Cape Cod, Martha's Vineyard, and Nantucket Island]

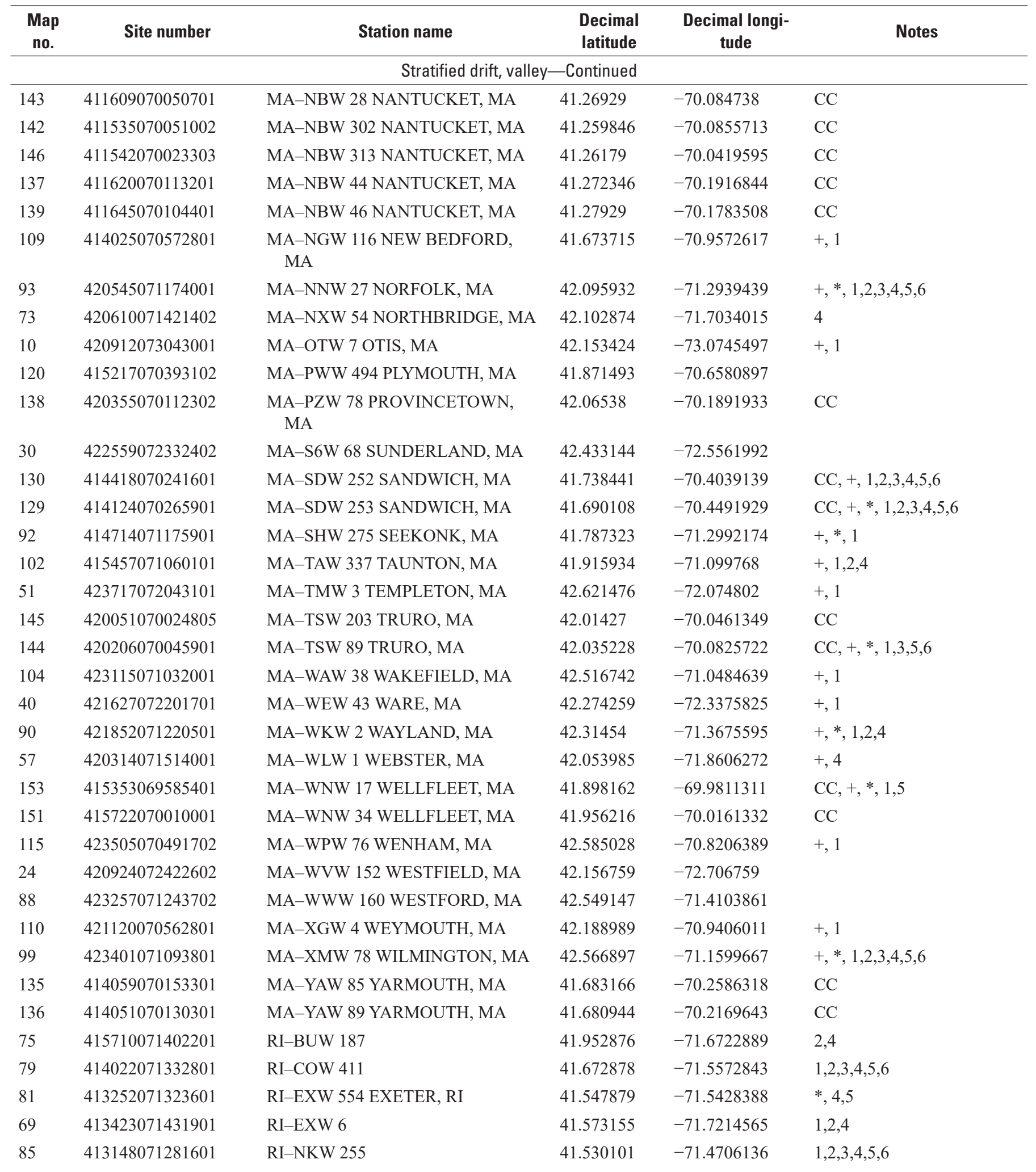


Table 1.1. U.S. Geological Survey groundwater-observation wells in Massachusetts and surrounding States.-Continued

[Wells have been grouped by setting, designated as the surficial deposit (stratified drift or till) and the topographic position. Additional information on these wells can be found in Barclay and Mullaney (2020). Map no. refers to number on figure 2. Site number refers to the U.S. Geological Survey station number (U.S. Geological Survey, 2018). Numbers in the "Notes" column indicate the well was used for the corresponding trend period from table 2 of this report. *, continuous record well; +, well used in analysis of Frimpter (1981); CC, Cape Cod, Martha's Vineyard, and Nantucket Island]

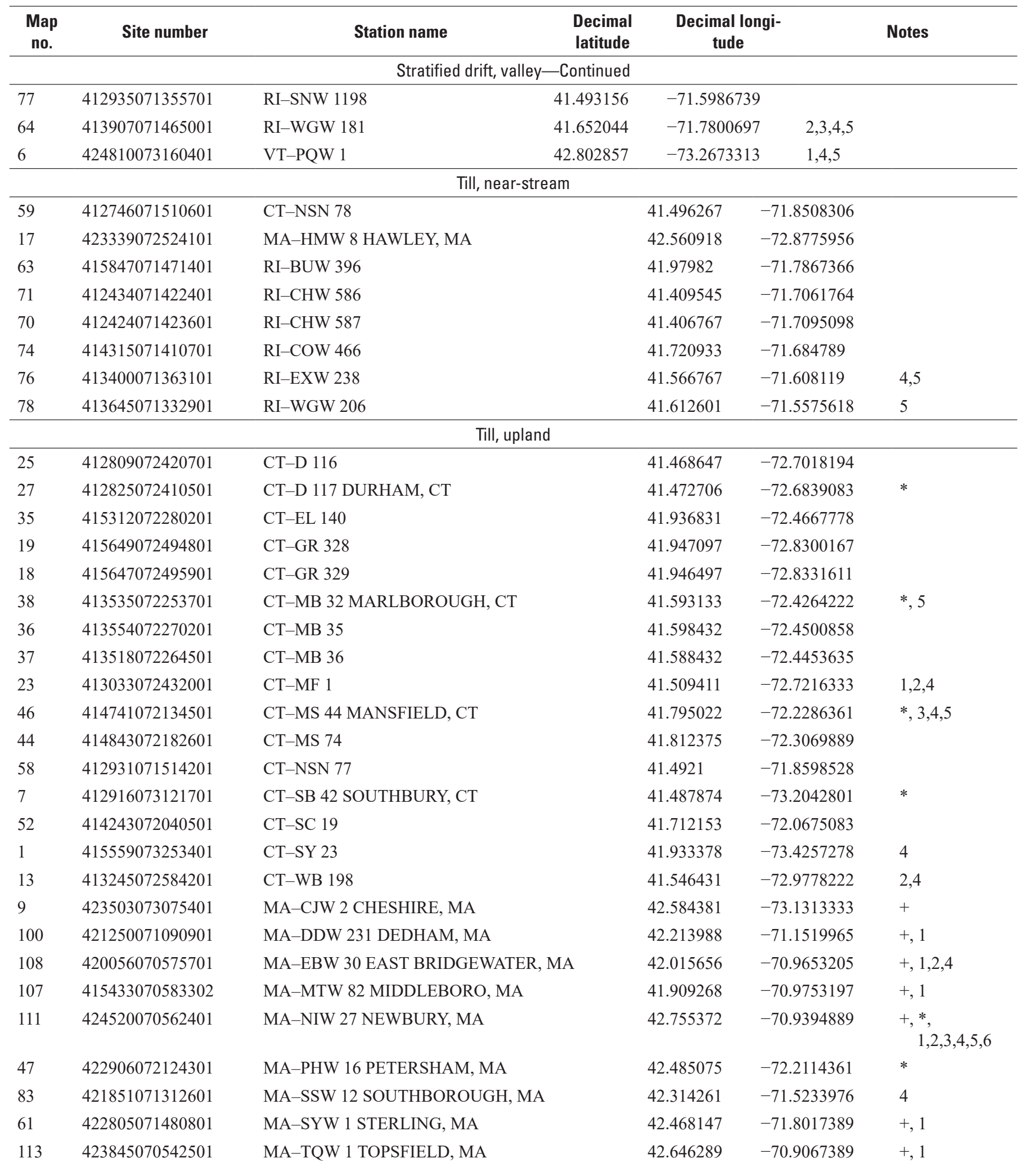


Table 1.1. U.S. Geological Survey groundwater-observation wells in Massachusetts and surrounding States.-Continued

[Wells have been grouped by setting, designated as the surficial deposit (stratified drift or till) and the topographic position. Additional information on these wells can be found in Barclay and Mullaney (2020). Map no. refers to number on figure 2. Site number refers to the U.S. Geological Survey station number (U.S. Geological Survey, 2018). Numbers in the "Notes" column indicate the well was used for the corresponding trend period from table 2 of this report. *, continuous record well; +, well used in analysis of Frimpter (1981); CC, Cape Cod, Martha's Vineyard, and Nantucket Island]

\begin{tabular}{lrllll}
\hline $\begin{array}{c}\text { Map } \\
\text { no. }\end{array}$ & Site number & \multicolumn{1}{c}{ Station name } & $\begin{array}{c}\text { Decimal } \\
\text { latitude }\end{array}$ & $\begin{array}{c}\text { Decimal longi- } \\
\text { tude }\end{array}$ & Notes \\
\hline \multicolumn{7}{c}{ Till, upland-Continued } \\
\hline 56 & 424204072015201 & MA-XNW 13 WINCHENDON, MA & 42.701019 & -72.0308361 &,+ 1 \\
101 & 422819071065701 & MA-XOW 14 WINCHESTER, MA & 42.47204 & -71.1153312 &,+ 1 \\
62 & 415546071474701 & RI-BUW 395 BURRILLVILLE, RI & 41.929543 & -71.7959035 & \\
72 & 414420071422301 & RI-FOW 40 & 41.738988 & -71.7059009 & 4,5 \\
66 & 413126071455501 & RI-HOW 67 & 41.523988 & -71.7647912 & 4 \\
96 & 413220071115501 & RI-LTW 142 & 41.538992 & -71.1981017 & \\
89 & 414106071223901 & RI-WCW 59 & 41.685101 & -71.3769985 & \\
\hline
\end{tabular}




\section{Appendix 2. Description of Data Used in the Predictive Equation To Select the Best Index Well}

The data used in this analysis are available in Barclay and Mullaney (2020).

\section{Data on Individual Network Wells}

Information about location (latitude, longitude, and elevation) and surficial material for each well was downloaded from the U.S. Geological Survey National Water Information System database (U.S. Geological Survey, 2018). Values for aspect, slope, topographic index, recharge, precipitation, topographic position index at 500 meters ( $\mathrm{m} ; 1,640$ feet [ft]), and topographic position index at 2,000 $\mathrm{m}(6,562 \mathrm{ft})$ at each network well were calculated by extracting the values from the appropriate raster to the shapefile of wells using the Extract Values to Points tool from the Spatial Analyst toolbox in ArcMap 10.5 (Esri, 2017).

The rasters for aspect and slope were calculated from the 1-arc-second National Elevation Dataset (U.S. Geological Survey, 2003) using the Aspect and Slope tools from the Spatial Analyst toolbox in ArcMap 10.5. Aspect was calculated using the geodesic method. Slope was calculated in degrees using the planar method. The raster for topographic index (TI) was calculated according to the following equation (Beven and Kirkby, 1979):

$$
T I=\ln \left(\frac{a}{\tan (b)}\right),
$$

where

$$
\begin{aligned}
& \text { represents the upslope contributing area per } \\
& \text { unit contour, and } \\
& b \quad \text { represents the angle of the slope, in radians. }
\end{aligned}
$$

The upslope contributing area per unit contour was calculated with the Flow Direction tool, then the Flow Accumulation tool from the Spatial Analyst toolbox in ArcMap 10.5, and was finally multiplied by the raster-cell size. The slope, as calculated by the planar method, was converted from degrees to radians prior to calculation of the topographic index. Values for recharge were extracted from Reitz and others (2017). Values for precipitation were extracted from PRISM's 30-year normal-precipitation totals (PRISM Climate Group, 2012). Rasters for the topographic position index at $500 \mathrm{~m}(1,640 \mathrm{ft})$ and the topographic position index at $2,000 \mathrm{~m}(6,562 \mathrm{ft})$ were generated using the Topographic
Position Index tool from the Topography Tools 9.3 toolbox for ArcMap (Dilts, 2010); the tool created circular neighborhoods with radii of $500 \mathrm{~m}(1,640 \mathrm{ft})$ and 2,000 $\mathrm{m}(6,562 \mathrm{ft})$, respectively. The toolbox has since been superseded by two other toolboxes: Land Facet Corridor Designer (Jenness and others, 2013) and Topography Tools for ArcGIS 10.3 and earlier (Dilts, 2015). Elevation above the nearest stream was read from a digital topographic map for each well. Distance to the nearest stream was calculated by joining the shapefile of wells to the nearest stream in the National Hydrography Dataset Plus (NHDPlus) flowline shapefile (U.S. Environmental Protection Agency and U.S. Geological Survey, 2012) using the spatial-join tool in the Analysis toolbox in ArcMap 10.5.

\section{Data on Well Pairs}

Correlations between water levels measured in each pair of wells were calculated using Spearman's rho (Helsel and Hirsch, 2002) to make a pairwise comparison (U.S. Geological Survey, 2015). Higher correlations between two wells indicate that water levels in the wells change at the same times and in the same directions (deeper or shallower), although the actual magnitude of water-level change may differ between the wells.

If both wells in the pair were finished in the same surficial deposit, the Same Surficial Deposit attribute was set to 1; otherwise it was set to 0 . Similarly, if both wells in the pair were in the same topographic setting, the Same Topographic Setting attribute was set to 1 ; otherwise it was set to 0 .

Proximity between two wells (proximity) was calculated as the Euclidean distance between the wells using the "NAD $1983^{1}$ State plane Massachusetts mainland FIPS2 2001 feet" projection. The distances were standardized by subtracting the mean and dividing by the standard deviation. The standardized distances were converted to proximity by multiplying by -1 so that larger values indicated smaller distances between the wells and smaller values indicated greater distances.

The similarity of the remaining variables (elevation, aspect, slope, topographic index, recharge, precipitation, topographic position index at $500 \mathrm{~m}$, topographic position index at 2,000 m, elevation above the nearest stream, and horizontal distance to the nearest stream) were calculated according to

\footnotetext{
1NAD 83 refers to the North American Datum of 1983.

${ }^{2}$ FIPS refers to the Federal Information Processing Standards.
} 
the following process: first, the absolute value of the difference between the values of the given variable was calculated for each well pair. Second, the absolute differences were standardized by subtracting the mean difference for all well pairs from the absolute difference for each well pair and then dividing the result by the standard deviation for all well pairs. Finally, the standardized differences were converted to similarities by multiplying by -1 so that larger values indicated greater similarity, and smaller values indicated less similarity. For example, if the elevation of well A is $300 \mathrm{ft}$, and the elevation of well B is $400 \mathrm{ft}$, the absolute value of the difference is 100 $\mathrm{ft}$. If the mean absolute difference between all pairs of wells is $500 \mathrm{ft}$, and the standard deviation of the absolute differences between all well pairs is $1,000 \mathrm{ft}$, then the standardized difference between the elevations of well $\mathrm{A}$ and well $\mathrm{B}$ is -0.4 $([100 \mathrm{ft}-500 \mathrm{ft}] / 1,000 \mathrm{ft})$. Converted to a similarity, the standardized similarity in elevation is 0.4 .

\section{Prediction Model Outputs}

The regression equation was used to estimate the correlation (Spearman's rho) between pairs of wells as the first step in predicting the most highly correlated index well. Each well, in turn, served as the base well (representing a potential test site), and the correlation with each other well was estimated using the prediction model coefficients (table 6 of this report) for the surficial deposits of the base well. This means that the correlation between each pair of wells was predicted twice (with each well serving as the base well once and as the potential index well once). If the two wells were finished in the same surficial deposit, the predicted correlations should be the same, regardless of which well is the base well. If the two wells were finished in different surficial deposits, however, the predicted correlations might differ because of differing model coefficients based on the surficial deposit location of the base well.

\section{References Cited}

Barclay, J.R., and Mullaney, J.R., 2020, Data on well characteristics and well-pair characteristics for estimating high groundwater levels in selected areas of Massachusetts: U.S. Geological Survey data release, https://doi.org/10.5066/ P9NM2PHP.

Beven, K.J., and Kirkby, M.J., 1979, A physically based, variable contributing area model of basin hydrology/Un modèle à base physique de zone d'appel variable de l'hydrologie du bassin versant: Hydrological Sciences Bulletin, v. 24, no. 1, p. 43-69. [Also available at https://doi.org/10.1080/ 02626667909491834.]
Dilts, T., 2010, Topography toolbox for ArcGIS 9.3: Esri ArcGIS Code Sharing web page, accessed February 15, 2015, at http://arcscripts.esri.com/details.asp?dbid=15996.

Dilts, T., 2015, Topography tools for ArcGIS 10.3 and earlier [updated September 4, 2019]: Esri ArcGIS web page, accessed November 1, 2019, at https://www.arcgis.com/ home/item.html?id=b13b3b40fa3c43d4a23ala09c5fe96b9.

Esri, 2017, An overview of the spatial analyst toolbox: Esri ArcGIS web page, accessed April 9, 2020, at https://desktop.arcgis.com/en/arcmap/10.5/tools/spatialanalyst-toolbox/an-overview-of-the-spatial-analysttoolbox.htm.

Helsel, D.R., and Hirsch, R.M., 2002, Statistical methods in water resources: U.S. Geological Survey Techniques of Water-Resources Investigations, book 4, chap. A3, 523 p., accessed October 17, 2019, at https://doi.org/10.3133/ twri04A3.

Jenness, J., Brost, B., and Beier, P., 2013, Land facet corridor designer: Jenness Enterprises web page, accessed November 1, 2019, at http://www.jennessent.com/arcgis/ land_facets.htm.

PRISM Climate Group, 2012, 30-year mean annual precipitation: Northwest Alliance for Computational Science \& Engineering website, accessed October 1, 2018, at http://prism.oregonstate.edu.

Reitz, M., Sanford, W.E., Senay, G., and Cazenas, J., 2017, Annual estimates of recharge, quick-flow runoff, and evapotranspiration for the contiguous U.S. using empirical regression equations: Journal of the American Water Resources Association, v. 53, no. 4, p. 961-983. [Also available at https://doi.org/10.1111/1752-1688.12546.]

U.S. Environmental Protection Agency and U.S. Geological Survey, 2012, WATERS (watershed assessment, tracking \& environmental results system): U.S. Environmental Protection Agency website, accessed at November 1, 2019, https://www.epa.gov/waters.

U.S. Geological Survey, 2003, 1 arc-second national elevation dataset (NED): U.S. Geological Survey The National Map data, scale 1:24,000, accessed November 28, 2018, at https://viewer.nationalmap.gov/basic/?category=ned.

U.S. Geological Survey, 2015, Statistic USGS water science R functions: U.S. Geological Survey GitHub USGS-R/ smwrStats web page, accessed November 28, 2018, at https://github.com/USGS-R/smwrStats.

U.S. Geological Survey, 2018, USGS water data for the Nation: U.S. Geological Survey data release, accessed January 18, 2018, at https://doi.org/10.5066/F7P55KJN. 

For more information about this report, contact: Director, New England Water Science Center U.S. Geological Survey

10 Bearfoot Road

Northborough, MA 01532

dc_nweng@usgs.gov

or visit our website at

https://www.usgs.gov/centers/new-england-water

Publishing support provided by the Pembroke Publishing Service Center 
